\title{
A Sociopolitical Perspective to Understand When and Why Supervisors Endorse and Implement Employees' Suggested Changes
}

Huaizhong Chen

hichen@mix.wvu.edu

Follow this and additional works at: https://researchrepository.wvu.edu/etd

Part of the Industrial and Organizational Psychology Commons, and the Organizational Behavior and Theory Commons

\section{Recommended Citation}

Chen, Huaizhong, "A Sociopolitical Perspective to Understand When and Why Supervisors Endorse and Implement Employees' Suggested Changes" (2019). Graduate Theses, Dissertations, and Problem Reports. 4099.

https://researchrepository.wvu.edu/etd/4099

This Thesis is protected by copyright and/or related rights. It has been brought to you by the The Research Repository @ WVU with permission from the rights-holder(s). You are free to use this Thesis in any way that is permitted by the copyright and related rights legislation that applies to your use. For other uses you must obtain permission from the rights-holder(s) directly, unless additional rights are indicated by a Creative Commons license in the record and/ or on the work itself. This Thesis has been accepted for inclusion in WVU Graduate Theses, Dissertations, and Problem Reports collection by an authorized administrator of The Research Repository @ WVU. For more information, please contact researchrepository@mail.wvu.edu. 
A Sociopolitical Perspective to Understand When and Why Supervisors Endorse and Implement Employees' Suggested Changes

\author{
Huaizhong Chen
}

Dissertation submitted

to the John Chambers College of Business and Economics

at West Virginia University

in partial fulfilment of the requirements for the degree of

Doctor of Philosophy in Business Administration

Concentration in Management

Edward Tomlinson, Ph.D., Chair

Nancy McIntyre, Ph.D.

James Field, Ph.D.

Marilyn Uy, Ph.D.

Department of Management

Morgantown, West Virginia

2019

Keywords: voice behavior, motive attribution, voice endorsement

Copyright 2019 Huaizhong Chen 


\begin{abstract}
A Sociopolitical Perspective to Understand When and Why Supervisors Endorse and Implement Employees' Suggested Changes

Huaizhong Chen
\end{abstract}

When employees make suggestions for changes to their supervisors, they are providing raw materials potentially critical to the organization's continuous improvement and adaptation. However, research suggests that supervisors do not always react favorably to employee voice behavior. The purpose of this study is to unravel the mediating and moderating mechanisms that can explain when and why employee voice behavior leads to supervisor endorsement and implementation. Specifically, taking a sociopolitical perspective, I argued that supervisor motive attributions for employee voice behavior can explain the extent to which supervisors endorse and subsequently implement employee voice. Furthermore, I argued that the mediating effects of supervisor motive attributions in the relationship between employee voice behavior and supervisor voice endorsement are moderated by employee political skills in the first stage of the mediating path (i.e., from voice behavior to supervisor motive attributions) and by supervisor perceived instrumentality of implementing employee voice in the second stage of the mediating path (i.e., from supervisor motive attributions to supervisor endorsement). Through a three-wave, multi-source field study, I first found that employee voice behavior is positively related to both supervisor prosocial and self-serving motive attributions for employee voice. Second, I found that employee political skills significantly moderate the relationship between employee voice behavior and supervisor prosocial motive attribution in an unexpected pattern, while employee political skills do not moderate the relationship between employee voice and supervisor selfserving motive attribution. Third, I found that supervisor prosocial motive attribution is positively associated with supervisor voice endorsement, whereas supervisor self-serving motive attribution has no significant effect on voice endorsement. Fourth, I found that supervisor perceived instrumentality of implementing employee voice significantly moderates the effect of supervisor prosocial motive attribution on voice endorsement in an unexpected manner while supervisor perceived instrumentality significantly moderates the effect of supervisor self-serving motive attribution on voice endorsement as predicted. Finally, I found that supervisor voice endorsement is significantly associated with voice implementation. Although a few of the hypothesized relationships were inconsistent with what was originally predicted, the study findings revealed some interesting and novel interactive patterns. Theoretical and practical implications of these findings were discussed. 


\section{ACKNOWLEDGEMENTS}

I would like to thank many people who have helped me reach this final stage of my doctoral study at West Virginia University. Without these people, I would not have reached this point. First, I would like to express my sincere appreciation to my committee: my chair Dr. Edward Tomlinson, and committee members Dr. Nancy McIntyre, Dr. James Field, and Dr. Marilyn Uy. Their insightful comments and developmental feedback helped me improve my dissertation. Undoubtedly, I would not have made it this far without my committee's strong support, guidance, and encouragement along the way. Second, I would like to thank two methodologists in the fields of management and psychology, Dr. Kristopher Preacher and Dr. Jeffery Edwards, for their advice on how to use Monte Carlo simulations to estimate sample size and power. Third, I would like to thank all the professors at West Virginia University who gave me guidance. I especially want to express my great gratitude to Dr. Abhishek Srivastava and Dr. Olga Bruyaka for being so nurturing and supportive. I also want to thank Dr. Jeffery Houghton, Dr. David Dawley, Dr. Ryan Angus, and Dr. Suzanne Kitchen for being very caring and encouraging. Fourth, I am very grateful to my friend Jiming Sun who always provides me with great support without any reservation and to my fellow Ph.D. students for the memorable time when we discussed research ideas together. Fifth, I want to thank the professors I worked with before I joined the Ph.D. program. They are Dr. Michael Frese, Dr. Zhaoli Song, and Dr. Sandy Lim. My research experience started with working with them. I appreciate their recommendations. Finally, my deepest gratitude goes to my family for their love and company. 


\section{TABLE OF CONTENTS}

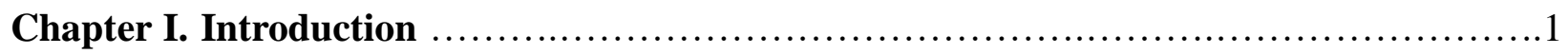

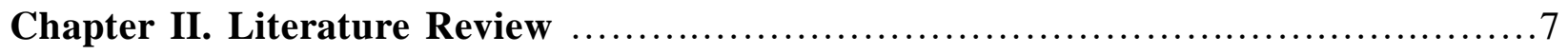

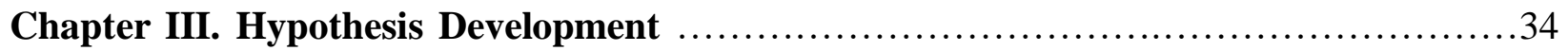

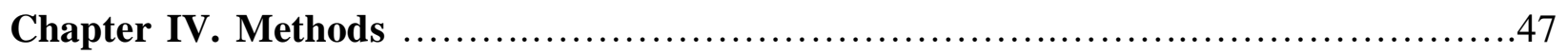

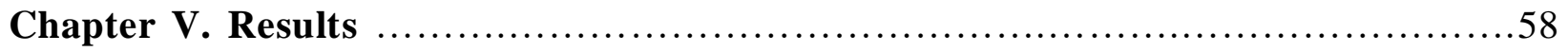

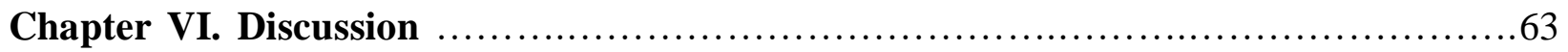

References.................................................................... 76

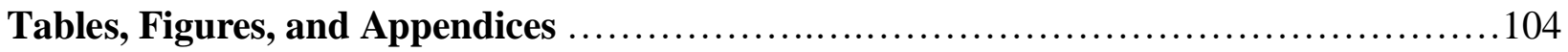

Table 1. Voice Behavior Definitions ............................................ 104

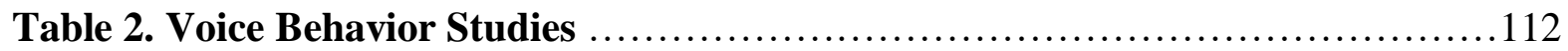

Table 3. Descriptive Statistics and Bivariate Correlations .....................120

Table 4. Comparisons of Measurement Models of Studied Variables ................121

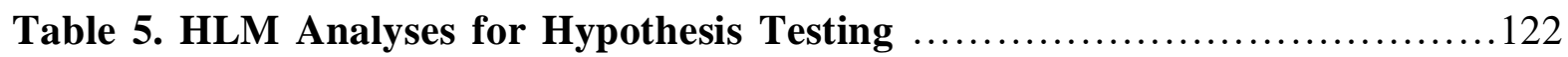

Table 6. Moderated Mediation Effect of Prosocial Motive Attribution .............123

Table 7. Moderated Mediation Effect of Self-serving Motive Attribution ..............124

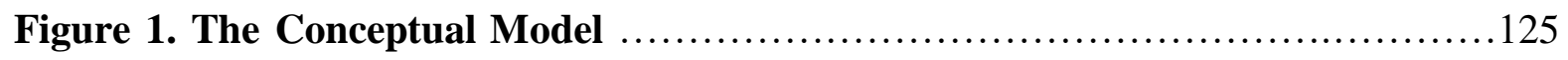

Figure 2. Voice Behavior * Political skills on Prosocial Motive Attribution...........126

Figure 3. Prosocial Motive Attribution * Instrumentality on Endorsement ..........127

Figure 4. Self-serving Motive Attribution * Instrumentality on Endorsement .........128

Figure 5. The Research Model with Path Coefficients........................... 129

Appendix A. List of Survey Instruments used in This Study .....................130

Appendix B. List of Original Survey Instruments Developed by Scholars.............134 


\section{CHAPTER I. INTRODUCTION}

Voice behavior is defined as discretionary and status-quo challenging verbal behavior intended to benefit the organization and/or people in the organization (Van Dyne \& LePine, 1998). Employees' suggestions for change or improvement in current policies, work procedures, or management practices have been argued to be critical to an organization's continuous development and adaptation (Katz, 1964; LePine \& Van Dyne, 1998). As Katz (1964, p. 133) noted, "people who are close to operating problems can often furnish informative suggestions about such operations."

Although employee voice behavior is intended for improvement, supervisors do not always appreciate it (Burris, 2012; Fast, Burris, \& Bartel, 2014; Howell, Harrison, Burris, \& Detert, 2015). Supervisors may reward employee voice behavior by giving high performance ratings (Howell et al., 2015). However, supervisors also may interpret employee voice behavior as challenging, threatening, and rocking the boat (Detert \& Burris, 2007; Fast et al., 2014). I aim to investigate when and why supervisors will endorse and implement employees' suggestions.

It is important to study supervisors' reactions to employee voice behavior. First, effecting change, especially at the unit-level, requires a supervisor's approval and support (Detert, Burris, Harrison, \& Martin, 2013; Liu, Tangirala, \& Ramanujam, 2013; McClean, Burris, \& Detert, 2013). If a supervisor does not endorse and implement suggested change, it is unlikely the organization will benefit from employees' suggestions. In addition, supervisors' reactions to employee voice behavior also affect employees' future voice behavior and their commitment to the organization. For example, employees' future voice behavior will be less likely to happen when they perceive their supervisors to be less receptive to their change-oriented suggestions (Detert \& Burris, 2007; Liu, Zhu, \& Yang, 2010). Also, employees engaging in voice behavior 
are more likely to leave the organization if they perceive the manager's willingness to change is low (McClean et al., 2013).

The extant voice behavior literature has explored mechanisms to explain supervisors' reactions to employee voice behavior, such as managerial self-efficacy (Fast et al., 2014), managerial ego-threats (Fast et al., 2014), and employees' status cued by their demographic information (e.g., ethnicity, Howell et al., 2015). I argue supervisors' motive attributions for employee voice behavior as additional mechanisms. Motive attributions refer to cognitive processes by which people explain the cause of a given behavior or event (Halbesleben, Bowler, Bolino, \& Turnley, 2010). Taking a sociopolitical perspective (Hogan \& Shelton, 1998; Yuan \& Woodman, 2010), I argue the mediating effects of supervisors' motive attributions will be conditional on two factors: 1) employee political skills and 2) supervisors' perceived instrumentality of implementing employee voice. Prior research has highlighted that attempts to effect change in the workplace are sociopolitical processes (Baer, 2012; Dutton, Ashford, O’Neill, Hayes, \& Wierba, 1997; Janssen, 2005; Yuan \& Woodman, 2010). Employees' abilities to effectively navigate and influence the sociopolitical process will enhance the likelihood of their ideas or suggestions being endorsed and implemented (Burris, 2012; Dutton et al., 1997; Yuan \& Woodman, 2010). Thus, I argue that employees' political skills will enable their ideas to be expressed in socially adaptive ways such that their supervisors will be more likely to make a prosocial motive attribution and less likely to make a self-serving motive attribution for their voice behavior. Furthermore, when people decide whether to endorse or implement suggested change, they have sociopolitical considerations, such as their image and reputation gains (Dutton et al., 1997), potential conflicts of interests among people (Janssen, 2003), and perceived threats to their status (Menon, Thompson, \& Choi, 2006). Hence, I argue that supervisors' perceived 
instrumentality of implementing employee voice will moderate the relationships between supervisors' motive attributions and their voice endorsement.

Perceivers' motive attributions for actors' behaviors have been argued to impact perceivers' reactions to actors' behaviors (Ferris, Bhawuk, Fedor, \& Judge, 1995; Weiner, 1980). Moreover, supervisors' motive attributions are likely to be triggered when employees engage in voice behavior. As a form of proactive and prosocial behavior, voice behavior challenges existing practice and is therefore likely to deviate from established norms and role expectations (Burris, 2012; Van Dyne \& LePine, 1998). It has been suggested that people are more likely to make motive attributions for actors' unexpected behaviors relative to their expected behaviors (Bowler, Halbesleben, \& Paul, 2010; Pyszczynski \& Greenberg, 1981).

When does employee voice behavior affect supervisors' reactions to voice through supervisors' motive attributions? As mentioned above, I argue that the mediating effects of supervisors' motive attributions will be dependent on two factors: 1) employee political skills and 2) supervisors' perceived instrumentality of employees' suggested changes.

First, political skills have been conceptualized as a social effectiveness construct and observed to be a stronger predictor of performance evaluation relative to other social effectiveness constructs, such as self-monitoring and emotional intelligence (Semadar, Robins, \& Ferris, 2006). Scholars have acknowledged the importance of actors' social effectiveness in others' perceptions of actors' behaviors (Gangestad \& Snyder, 2000; Hogan \& Shelton, 1998). According to socio-analytic theory (Hogan \& Shelton, 1998), actors' behaviors reflect their aspirations and motivation, and observers tend to understand actors' aspirations and motivation through actors' exhibited behaviors. Actors' social effectiveness impacts their abilities to influence observers' interpretations of their aspirations and motivation (Harris, Kacmar, 
Zivnuska, \& Shaw, 2007; Witt \& Ferris, 2003). In spite of the importance of actors' social effectiveness in affecting others' reactions to actors' behaviors, no research has examined how employees' political skills impact supervisors' motive attributions for employee voice behavior. I argue the strength of employees' political skills will impact their abilities to communicate their suggestions for change effectively. Specifically, when employees have higher levels of political skills and share more suggestions, supervisors are more likely to perceive a prosocial motive and less likely to perceive a self-serving motive.

Furthermore, according to previous research (Bolino, 1999; Halbesleben et al., 2010; Weiner, 1980), people's motive attributions for an actor's behavior affect their reactions to this behavior. Specifically, people tend to react favorably to an actor's behavior when the behavior is perceived as prosocial. In contrast, people tend to react negatively to an actor's behavior when the behavior is perceived as manipulative and self-serving. Nevertheless, in the context of employee voice behavior, motive attributions may not be a sufficient reason for supervisors to endorse and implement suggested changes. I argue supervisors' perceived instrumentality of implementing suggested changes is also important to supervisors' reactions to employee voice behavior. This is because any attempt to introduce change consumes resources and may result in costs and conflicts among employees (Baer, 2012; Janssen, 2003). When supervisors decide whether to endorse and implement suggested changes, supervisors may weigh potential benefits and costs associated with suggested changes. I argue supervisors' motive attributions will interact with their perceived instrumentality of implementing suggested changes to affect their voice endorsement and implementation. Specifically, as supervisors perceive greater instrumentality of implementing employee voice, the positive effect of supervisor prosocial 
motive attribution on voice endorsement will be strengthened and the negative effect of supervisor self-serving motive attribution on voice endorsement will be weakened.

The theoretical contributions of this study are fourfold. First, this study contributes to the voice behavior literature by highlighting the roles of motive attributions in explaining supervisor voice endorsement and in turn voice implementation. It is of importance to understand why supervisors endorse and implement suggestions voiced by employees. As mentioned earlier, supervisors' reactions (e.g., voice endorsement and implementation) to employee voice behavior affect whether the organization will potentially benefit from the suggested changes voiced by employees. Researchers have argued that it is hard for employees to effect unit-level changes without supervisors' support or approval (Detert et al., 2013). Also, supervisors' reactions to employee voice behavior affect employees' future engagement in voice behavior (Detert \& Burris, 2007; Liu et al., 2010) and their commitment (McClean et al., 2013). Motive attributions have been observed to impact observers' reactions to actors' behaviors (Halbesleben et al., 2010; Weiner, 1980). As a non-required behavior which deviates from established norms and role expectations, employee voice behavior may trigger supervisors' motive attributions (Bowler et al., 2010; Pyszczynski \& Greenberg, 1981). However, we have little understanding of how motive attributions impact supervisors' reactions to employee voice behavior. This study extends the voice behavior literature by examining the roles of supervisors' motive attributions in their reactions to employee voice behavior.

Second, this study extends our understanding of voice behavior by examining the roles of employees' political skills in supervisors' motive attributions for employee voice behavior. The extant voice literature implicitly assumes that the mere demonstration of voice behavior is equivalent to its effectiveness. That is, there is no research investigating whether and how 
employees' social effectiveness, such as political skills, may interact with their voice behavior to affect others' perceptions of such behavior. Although voice behavior has been primarily conceptualized as a prosocial behavior (Van Dyne \& LePine, 1998), employees’ social effectiveness may influence supervisors' interpretations of employee voice behavior. This study contributes to the voice behavior literature by suggesting political skills are necessary for employees' voice behavior to be perceived as prosocial and not self-serving.

Third, this study extends the voice and motive attribution literatures by investigating the role of supervisors' perceived instrumentality of suggested changes. Researchers have suggested that people's prosocial motive attribution for others' behaviors leads to favorable reactions and self-serving motive attribution leads to unfavorable reactions (Halbesleben et al., 2010; Weiner, 1980). This study advances our knowledge by examining whether the relationships between supervisors' motive attributions and reactions to voice vary depending on the levels of supervisors' perceived instrumentality of implementing suggested changes. 


\section{CHAPTER II. LITERATURE REVIEW}

Voice behavior has been conceptualized by Van Dyne and LePine (1998) as a challenging organizational citizenship behavior (OCB) and proactive behavior. This chapter starts with an introduction to the voice behavior literature and then reviews the OCB and proactive behavior literatures. Finally, this chapter highlights the similarities and differences between OCB and proactive behavior.

\section{VOICE BEHAVIOR}

This section starts with an introduction to different conceptualizations of voice behavior, then elaborates on the extant research findings related to voice behavior. Finally, this section identifies a research gap this study will address and other research gaps worthy of future investigation.

\section{Conceptualizations of Voice Behavior}

Scholars conceptualized voice behavior in different ways (Burris, 2012; Gordan, 1988; Hirschman, 1970; Van Dyne \& LePine, 1998), such as conceptualizing voice behavior as OCB and proactive behavior, or as any verbal behavior expressing complaints, support, or dissents. Nevertheless, Van Dyne and LePine's (1998) conceptualization of voice behavior has been most widely used in the extant voice behavior literature (Burris et al., 2008; Burris et al., 2013; Detert \& Edmondson, 2011; Liu et al., 2015).

It was Hirschman (1970) who first used the term "voice" as one of employees' responses to dissatisfaction. Specifically, Hirschman proposed a dissatisfaction framework of Exit-VoiceLoyalty (EVL) to understand employee responses to an organization's decline in its functioning. The first response is exit, which is equivalent to voluntary turnover from the organization. The second response is voice, which was defined as, "any attempt at all to change rather than to 
escape from an objectionable state of affairs" (Hirschman, 1970, p. 30). Voice involves upward verbal communication with authorities; actions, such as writing a letter to a government agency or labor unit; and protests (Farrell, 1983; Hirschman, 1970). The third response is loyalty. When employees are dissatisfied with current policies, work procedures, and management practices or notice deteriorating conditions in the organization, some employees choose to stick with the organization for a period of time before reacting to the problem. As Hirschman (1970, p. 38) described, employees who choose loyalty tend to "suffer in silence, confident that things will soon get better." Furthering Hirschman's framework, some scholars argued neglect is an additional response to dissatisfaction or organizational decline. Neglect refers to "passively allowing conditions to deteriorate through reduced interest or effort" (Rusbult, Farrell, Rogers, \& Mainous III, 1988, p. 601). Thus, the framework of Exit-Voice-Loyalty (EVL) was extended to Exit-Voice-Loyalty-Neglect (EVLN, Farrell, 1983; Rusbult et al., 1988).

Voice proposed by Hirschman (1970) is a relatively broad concept, which may include complaints, grievance filing, and suggestions by means of formal or informal systems. Alternatively, the majority of voice research in the field of organizational behavior has adopted the definition of voice put forth by Van Dyne and LePine (1998). Drawing on the literature on proactivity and OCB, Van Dyne and LePine (1998, p. 109) defined voice as a discretionary, promotive, and challenging behavior that "emphasizes expression of constructive change intended to improve rather than merely criticize." They considered voice as promotive behavior or proactive behavior that aims to make something happen instead of preventing something from happening (e.g., resistance to change). Also, they stressed that the nature of voice behavior is challenging, which is contrasted with affiliative OCB that aims to be supportive and cooperative (Van Dyne \& LePine, 1998). 
Consistent with the conceptualization of voice behavior by Van Dyne and LePine (1998), other researchers in the field of organizational behavior also conceptualized voice as a proactive and improvement-oriented behavior (Burris et al., 2008; Burris et al., 2013). They focused on upward communication because they argued people in higher organizational levels have the legitimate power and influence to implement changes suggested by employees (Burris, 2012). Indeed, while only a few studies have examined voice behavior directed at both supervisors and co-workers (Detert et al., 2013; Liu et al., 2015), most voice behavior studies have focused on upward communication (Detert \& Burris, 2007; Detert \& Edmondson, 2011; Howell et al., 2015; Tangirala \& Ramanujam, 2012).

As the voice behavior literature evolved, some scholars expanded the conceptualization of voice behavior, because they considered the current conceptualization to be too narrow. For example, some researchers argued other forms of voice behavior occur in organizations in addition to suggestion-based voice behavior, such as expressing support or defending the current policies and criticizing or complaining about the current procedures (Burris, 2012; Liang, Farh, \& Farh, 2012; Maynes \& Podsakoff, 2014).

Liang, Farh, and Farh (2012) expanded the conceptualization of voice behavior by including prohibitive voice behavior and thus distinguished promotive voice behavior and prohibitive voice behavior. Promotive voice behavior is consistent with Van Dyne and LePine's (1998) conceptualization of voice behavior. In contrast, prohibitive voice behavior refers to the expression of concerns about a harmful practice in an organization, aiming to avoid failure without offering a suggestion to rectify or improve the harmful practice (e.g., whistle-blowing, pointing out the insufficiency of the current procedure). The difference between the two is that the former points out potential problems and proposes suggestions for improvement while the 
latter only points out the inappropriate or insufficient practice without offering any ideas for improvement.

Burris (2012) also expanded the conceptualization of voice behavior by including supportive voice behavior and thus distinguished challenging voice behavior and supportive voice behavior. Burris (2012) conceptualized challenging voice behavior in accordance with Van Dyne and LePine's (1998) definition of voice behavior. However, Burris (2012) argued not all employee voice behaviors are challenge-oriented, and voice could seek to preserve existing policies or practices. Also, Burris (2012) pointed out the six-item voice behavior scale developed by Van Dyne and LePine (1998) was not consistent with their conceptualization of voice behavior. For example, Van Dyne and LePine (1998) conceptualized voice behavior as suggestion-based and challenge-oriented behavior; however, some measurement items, such as “... keeps well informed about issues where his/her opinions might be useful” are neither challenge-oriented nor suggestion-based. Thus, Burris (2012) distinguished challenging and supportive voice behaviors, revised the six items developed by Van Dyne and LePine (1998), and grouped the revised items into two three-item scales to measure supportive and challenging voice behaviors, respectively.

Maynes and Podsakoff (2014, p. 2) defined voice behavior as "an individual's voluntary and open communication directed towards individuals within the organization that is focused on influencing the context of the work environment." They distinguished four types of voice behavior: constructive voice behavior, destructive voice behavior, supportive voice behavior, and defensive voice behavior. They defined constructive voice behavior as, "the voluntary expression of ideas, information, or opinions focused on effecting organizationally functional change to the work context” (Maynes \& Podsakoff, 2014, p. 5), which is consistent with Van Dyne and 
LePine's (1998) conceptualization of voice behavior in the extant literature. Destructive voice behavior was defined as, "the voluntary expression of hurtful, critical, or debasing opinions regarding work policies, practices, procedures, etc.” (Maynes \& Podsakoff, 2014, p. 5). Examples of destructive voice behavior include bad-mouthing, criticism, and complaining behaviors. Supportive voice behavior was defined as, "the voluntary expression of support for worthwhile work-related policies, programs, objectives, procedures, etc., or speaking out in defense of these same things when they are being unfairly criticized" (Maynes \& Podsakoff, 2014, p. 5). Supportive voice behavior involves compliance and loyal behaviors, such as expressing support for organizational objectives and procedures and verbally defending organizational policies that other employees are criticizing. Defensive voice behavior was defined as, "the voluntary expression of opposition to changing an organization's policies, procedures, programs, practices, etc., even when the proposed changes have merit or making changes is necessary" (Maynes \& Podsakoff, 2014, p. 5). The typical defensive voice behavior involves behaviors intended to maintain the status quo and resist change.

These subsequent conceptualizations of voice behavior diverge sharply from Van Dyne and LePine's (1998) conceptualization. For example, Liang, Farh, and Farh (2014) included behaviors pointing out problems without offering suggestions for improvement, which dismiss the nature of voice behavior as suggestion-based (Katz, 1964; Van Dyne \& LePine, 1998). Maynes and Podsakoff (2014) included behaviors like bad-mouthing, complaints, and resistance to change, which deviate dramatically from the constructive nature of voice as conceptualized by Van Dyne and LePine (1998).

Furthermore, it is noteworthy that Van Dyne and LePine's (1998) conceptualization of voice behavior in the proactivity and OCB literature is distinct from the conceptualization of 
voice in the procedural justice literature. The justice literature suggests employees' reactions to decisions depend on the outcomes associated with these decisions and employees' perceptions of the decision-making process (Brockner et al., 1998). In the procedural justice literature, voice refers to the extent to which people are allowed to provide opinions or suggestions in the decision process (Brockner et al., 1998; Thibaut \& Walker, 1975), which captures opportunities for voice behavior (e.g., open-door policy, grievance procedure) rather than voice behavior itself. In the current study, I adopt the widely accepted conceptualization of voice behavior proposed by Van Dyne and LePine (1998) since I am interested in studying voice behavior as an OCB and proactive behavior. Specifically, I conceptualize voice behavior as a discretionary, status-quo challenging, and suggestion-based behavior which is intended to benefit an organization or people in the organization. Also, I will investigate upward voice behavior. As researchers have pointed out, employees speak up to their supervisors because supervisors, relative to peers, are more likely to have the position and legitimate power to mobilize resources to implement suggested changes (Burris, 2012; Detert \& Edmondson, 2011; Howell et al., 2015).

Table 1 presents an exhaustive list of definitions of voice behavior. To compile the list, I searched the literature via Google Scholar and Web of Science using keywords: voice, voicing, speak up, speaking up, upward communication, suggestion, dissent, idea sharing, challenging verbal, verbally challenge, proactivity, proactive, and proactive behavior. Also, I looked for additional literature by checking the reference lists of the available articles or chapters.

A list of empirical studies of voice behavior is included in Table 2. A few articles on voice behavior were reviewed but not included in Table 2. These are narrative reviews (Klaas, Olson-Buchanan, \& Ward, 2012; McCabe \& Lewin, 1992, Morrison, 2014) and articles examining the construct validity of voice behavior versus other behaviors (Van Dyne, Ang, \& 
Botero, 2003; Van Dyne \& LePine, 1998). As previously mentioned, most empirical studies on voice behavior adopted the conceptualization of voice behavior by Van Dyne and LePine (1998). Only a few studies adopted the expanded conceptualizations of voice behavior (Liang et al., 2012; Hsiung \& Tsai, 2017; McClean et al., 2017).

\section{Antecedents of Voice Behavior}

A large body of voice behavior literature has focused on investigating what factors contribute to employee voice behavior. This is because voice behavior has been argued to be a key factor in enhancing organizational effectiveness and adaptation (Burris, 2012; Morrison, 2014; Van Dyne \& LePine, 1998). For example, making constructive suggestions for change and improvement is the first step in an innovation process (Scott \& Bruce, 1994). Voice behavior makes it possible for an organization to channel employees' dissatisfaction with the status quo toward rectifying mistakes, improving procedures, and formulating novel solutions to organizational problems (Detert et al., 2013; Zhou \& George, 2001). Thus, researchers are interested in studying what factors promote employee voice behavior. The antecedents of voice behavior examined can be grouped into four broad categories: dispositional factors, psychological safety concerns, efficacy concerns, and utility concerns.

Dispositional factors. Employees’ proactive personality, conscientiousness, extraversion, core self-evaluation, and approach orientation have been observed to be positively related to voice behavior (Aryee, Walumbwa, Mondejar, \& Chu, 2017; Kakkar, Tangirala, Srivastava, \& Kamdar, 2016). Employees with higher levels of proactive personality have a future mindset and a stronger dispositional tendency to initiate change toward the future ideal state (Crant, 2000; Detert \& Burris, 2007; Parker \& Collins, 2010). Therefore, proactive employees are more likely to engage in proactive behaviors such as voice behavior. 
Conscientious employees are more likely to engage in voice behavior because they are detailand achievement-oriented. They are more likely to detect problems and more willing to spend effort on the discussion to solve problems (Chamberlin, Newton, \& LePine, 2017; LePine \& Van Dyne, 2001). Extraverted employees tend to engage in voice behavior because they are sociable, assertive, and talkative. Extraverted employees tend to feel uninhibited by social pressure (e.g., normative influence) to express different opinions (Chamberlin et al., 2017; LePine \& Van Dyne, 2001). Moreover, approach-oriented employees are attentive to the potential opportunities for success and are attuned to picturing the ideal future at work in their minds. Thus, they tend to engage in voice behavior when they have ideas for improvement (Kakkar et al., 2016).

Psychological safety concerns. Psychological safety is defined as "people's perceptions of the consequences of taking risks in a particular context such as a workplace" (Edmondson \& Lei, 2014, p. 24). As previously mentioned, voice behavior is risky due to its challenging and change-oriented nature. Not surprisingly, researchers have observed that psychological safety is a significant predictor of employees' voice behavior (Detert et al., 2013; Liu et al., 2015). In addition, contextual factors, such as managerial openness, managerial self-efficacy, managers' consultation behavior, transformational leadership, supervisors' positive affect, and procedural justice climate, have been observed to prompt employee voice behavior (Detert \& Burris, 2007; Farh \& Chen, 2018; Fast et al., 2014; Liu et al., 2015; Morrison, Wheeler-Smith, \& Kamdar, 2011; Tangirala \& Ramanujam, 2012). Researchers also have observed psychological safety to mediate the effects of these contextual factors on employee voice behavior (Detert et al., 2013; Liu et al., 2015; Walumbwa \& Schaubroeck, 2009).

Efficacy concerns. Efficacy concerns represent the extent to which employees believe they can enact voice behavior successfully or they have impact to influence others. Employees' 
efficacy concerns affect their engagement in voice behavior. For example, employees' personal control, personal influence, a sense of power, and organization-based self-esteem have been observed to be positively associated with employee voice behavior (Burris et al., 2008; Morrison, See, \& Pan, 2014; Van Dyne, Kamdar, Joireman, 2008; Venkataramani \& Tangirala, 2010). When employees have a greater impact and are valued by the organization, employees think their opinions will be considered more seriously (Tangirala, Kamdat, Venkataramani, \& Parke, 2013). When employees believe their suggestions will be taken seriously, they are more likely to speak up.

Implementation concerns. When employees engage in voice behavior, their supervisors may be unable to implement suggestions made by employees due to their lack of influence or limited access to resources. Thus, the extent to which employees' suggestions can be implemented is also an important consideration for employees when they decide whether to speak up. Indeed, the voice target's relationships with people at higher levels in the organization, access to organizational resources, and participation in the decision-making process have been observed to be positively associated with employee voice behavior (Liu et al., 2013; McClean et al., 2013). These factors signal to employees that voice targets have the potential to implement employees' recommendations.

\section{Outcomes of Voice Behavior}

Compared to a large number of studies on antecedents of voice behavior, only a few studies have examined the individual and unit-level outcomes of voice behavior. Two main individual outcomes have been examined: overall performance ratings by supervisors and supervisors' voice endorsement. For example, Burris (2012) observed challenging voice behavior is negatively associated with performance evaluations. Burris (2012) also observed 
supervisors' perceptions of employee disloyalty mediated the relationship between employee challenging voice behavior and employee performance evaluation. In addition to Burris' (2012) study, Fast, Burris, and Bartel (2014) explored factors leading to supervisors' aversion to employee voice behavior. They observed supervisors' aversive attitude toward employee voice behavior was a result of their low managerial self-efficacy and ego threats.

Furthermore, Howell, Harrison, Burris, and Detert (2015) observed supervisors are more likely to recognize suggestions brought up by employees who have higher ascribed status (whites versus non-whites), higher assigned status (incumbents versus newcomers), and higher achieved status (in-degree centrality in informal social structure). More recently, researchers investigated the relationship between characteristics of employee voice content and supervisors' voice endorsement. Voice endorsement refers to the extent to which supervisors believe suggested changes have potential value and are willing to take employees' suggestions to higher-level leaders (Burris, 2012). Burris, Rockmann, and Kimmons (2017) observed supervisors are more likely to endorse suggestions they consider more important, requiring fewer resources, and involving lower levels of dependence on other stakeholders across units for enacting the change. In a recent study (Lam, Lee, \& Sui, 2018), researchers have observed that supervisors are more likely to endorse employees' suggestions when employees are more credible and polite.

Researchers also have examined how promotive and prohibitive voice behaviors impact employees' leadership emergence (McClean et al., 2018). Specifically, employees' promotive voice behavior, but not prohibitive voice behavior, was positively and indirectly related to employees' leadership emergence through its positive effect on employee status. Moreover, employee gender has been observed to moderate the effect of employee voice behavior on 
employee status. Promotive voice behavior, but not prohibitive voice behavior, was observed to be positively related to employee status for men but not for women.

Two studies have examined the effects of aggregated employee voice behavior on unitlevel outcomes. The first study was conducted by Detert, Burris, Harrison, and Martin (2013). They observed the amount of employee voice behavior to supervisors was positively associated with supervisor-rated unit-level performance, while the amount of employee voice behavior to coworkers was negatively associated with supervisor-rated unit-level performance. This may be because supervisors are more likely than coworkers to have the position and legitimate power needed to enact a change at the unit level. Making suggestions to coworkers may lead to few substantive changes at the unit level and also generate a feeling of incapability and powerlessness among coworkers (Detert et al., 2013). In a second study, McClean, Burris, and Detert (2013) observed three factors representing managers' status and team climate for embracing change (i.e., manager access to organizational resources, manager participation in decision making, team change-oriented climate) moderate the unit-level relationship between employee voice behavior and employee turnover. The relationship between unit-level employee voice behavior and unit-level turnover changed from positive to negative as each of these three factors increased. The authors aggregated individual frequency of voice behavior to the unit level and used archival data to measure the unit-level employee turnover rate.

\section{The Research Gap to Be Addressed in This Study}

While the extant voice behavior literature has advanced our understanding of voice behavior at work, there are still some areas worthy of further investigation. First, as stated earlier, supervisors' reactions to employee voice behavior have far-reaching consequences, and we have limited knowledge of why and when supervisors react differently to employee voice 
behavior. This study aims to contribute to this research gap by examining supervisors' motive attributions as mechanisms through which employee voice behavior affects supervisors' voice endorsement and implementation. This study will further examine two conditions, employee political skill and supervisors' perceived desirable outcomes of suggested changes, under which the indirect effects of employee voice on supervisors' reactions via supervisors' motive attributions may vary.

\section{Other Research Gaps Identified for Future Investigation}

Another critical gap in the voice behavior literature worthy of future investigation is the relationship between employee voice behavior and unit-level or organizational level outcomes. As reviewed in the prior section, only three studies have investigated the effects of voice on higher-level outcomes. Detert, Burris, Harrison, and Martin (2013) examined the effects of unitlevel voice behaviors on leaders' perceptions of unit effectiveness, while McClean, Burris and Detert (2013) examined unit-level employee turnover rate. In another study, researchers have observed team promotive voice behavior contributes to team productivity performance through team innovation and team prohibitive voice behavior contributes to team safety performance through team monitoring ( $\mathrm{Li}, \mathrm{Liao}$, Tangirala, \& Firth, 2017). More research is needed to examine the relationship between employee voice behavior and these and other indicators of unit-level or organizational level outcomes (e.g., customer satisfaction, sales volume). As scholars have noted, voice behavior has been assumed to be important to organizational functioning and effectiveness (Morrison, 2014; Mowbray et al., 2015), but additional evidence is needed.

Finally, there may be an opportunity for future research to study the effects of people's cultural values on employee voice behavior. Botero and Van Dyne (2009) observed employees' 
power distance orientation is negatively associated with employee voice behavior. It was posited that people's cultural values also may impact voice behavior in addition to people's power distance orientation (Morrison, 2014). Researchers argued people's cultural values are important in understanding individuals' behaviors because they are associated with norms about roles and communication (Botero \& Van Dyne, 2009; Hirokawa \& Miyahara, 1982). Thus, it would be worth investigating the effects of cultural values (e.g., uncertainty aversion) on employee voice behavior, especially in organizations where there is great ethnic diversity (Morrison, 2014; Mowbray et al., 2015). In addition, researchers also observed cultural differences in upward communication at the societal or national level. Employees in the United States have been observed to engage in more frequent feedback seeking behaviors than employees in Hong Kong (Morrison, Chen, \& Salgado, 2004). Morrison (2014) argued the difference in upward communication also may be due to the self-assertiveness dimension of individualism versus collectivism. Morrison (2014) hypothesized that cultures characterized by assertiveness may have a positive effect on employee voice behavior. Future research may examine this proposition and examine mechanisms through which cultural differences impact voice behavior.

As previously mentioned, I adopt Van Dyne and LePine's (1998) conceptualization of voice behavior in this study because I am interested in studying voice behavior as a challenging OCB and proactive behavior. Hence, in the next sections, I review the literatures on organizational citizenship behavior (OCB) and proactive behavior and highlight the similarities and differences between OCB and proactive behavior. 


\section{Organizational Citizenship Behavior (OCB)}

\section{What is OCB?}

Organizational citizenship behavior (OCB) is defined as "behavior that is discretionary, not directly or explicitly recognized by the formal reward system, and that in the aggregate promotes the effective functioning of the organization" (Organ, 1988, p. 4). Organizational citizenship behavior (OCB) is desirable behavior in organizations (Podsakoff \& MacKenzie, 1997; Podsakoff, Whiting, Podsakoff, \& Blume, 2009). As Katz (1964) noted, carrying out role assignments is fundamentally important to an organization, but an organization cannot function well if it merely relies on employee in-role behaviors. Williams and Anderson (1991) defined inrole behaviors as all the behaviors necessary for the completion of work specified in the job description. No organization can foresee all situations that may lead to problems in its operations or anticipate all the environmental changes (Katz, 1964). Employees are thus expected to exhibit organizational citizenship behaviors when needed, such as providing emotional support to coworkers in need to promote their emotional wellbeing, sharing knowledge and experience among team members to solve a new problem, and making suggestions to marketing managers to adjust the current customer service policies in response to customers' changing needs. Thus, employees' OCB is vital to and desired by organizations (Katz, 1964; Organ, 1988; Podsakoff et al., 2009).

\section{Why do Employees Engage in OCB?}

Organizational citizenship behavior (OCB) is discretionary behavior intending to benefit others or organizations, and are not formally rewarded (Organ, 1988). Scholars in this area have been seeking to understand why people engage in this non-required behavior. There are four primary perspectives to understand people's engagement in OCB: the evolutionary perspective 
(Salamon \& Deutsch, 2006; Sober \& Wilson, 1998), the dispositional perspective (Podsakoff et al., 2009), the reciprocity norm perspective (Bolino \& Grant, 2016; Podsakoff et al., 2000), and the management impression or self-promotion perspective (Bolino, 1999).

The evolutionary perspective has suggested that natural selection happens at the group rather than at the individual level, and groups consisting of a higher percentage of altruistic individuals are argued to be more likely to survive than groups with a lower percentage of altruistic individuals (Sober \& Wilson, 1998). This is because altruistic individuals are willing to sacrifice their own welfare for the collective well-being (Salamon \& Deutsch, 2006; Sober \& Wilson, 1998). People in a group have been argued to be evolutionarily prone to prosocial behavior to improve their chances for survival.

Researchers taking the dispositional perspective have argued that people engage in prosocial behavior because they have some predisposition to help or please others and facilitate teamwork (Podsakoff et al., 2009). For example, agreeableness and conscientiousness have been observed to be positively associated with OCB (Podsakoff et al., 2009).

A dominant perspective for OCB comes from those who believe it is based on the reciprocity norm. It has been postulated that reciprocity is a governing norm that guides people's behaviors (Thibaut \& Kelley, 1959; Trivers, 1971). When employees hold favorable job attitudes or are treated fairly by colleagues or organizations, they tend to reciprocate by exhibiting OCB (Bolino \& Grant, 2016; Podsakoff et al., 2000). Alternatively, researchers have argued that employees may engage in OCB to build favorable exchange relationships (Salamon \& Deutsch, 2006). For example, an employee may take initiative to help others because the employee may expect others will help him/her in the future. 
The impression management or self-promotion perspective has viewed OCB as a means of establishing a desirable public image or for obtaining desired individual outcomes (Bolino, 1999; Flynn, Reagans, Amanatullah, \& Ames, 2006; Hui, Lam, \& Law, 2000). For instance, people have been observed to gain higher social status when they exhibit more helping behaviors and ask for less help from others (Flynn et al., 2006). Social status is "conferred to people on the basis of their apparent possession of attributes (e.g., competence, generosity) held as ideal by other members of their social group" (Flynn et al., 2006, p.1123). People helping others and refraining from asking for help tend to create an image of competence since they are relatively less dependent on others while others are more dependent on them. In addition to social status, OCB also can lead to other desired individual outcomes, such as promotions at work. For instance, it has been observed that employees who perceive OCB to be more instrumental to promotion are more likely to perform OCB than those who perceive OCB to be less instrumental to promotion (Hui et al., 2000). Interestingly, Hui et al. (2000) also observed employees who perceive greater instrumentality of OCB and who get promoted are more likely to reduce their OCB after they get promoted. Comparatively, employees who either perceive OCB to be less instrumental for promotion or do not get promoted are less likely to reduce their OCB after promotion decisions (Hui et al., 2000).

\section{What are the Consequences of OCB?}

In addition to understanding why people engage in OCB, researchers also have investigated unit/organization-level and individual-level consequences of OCB. As conceptualized by Organ (1988), OCB will contribute to organizations. Indeed, it has been observed that OCB is positively related to unit/organization performance, such as customer satisfaction and unit/organization-level productivity and negatively related to unit/organization- 
level turnover rate (MacKenzie, Podsakoff, \& Ahearne, 1998; Podsakoff et al., 2009).

Researchers have explained that OCB may contribute to an organization's performance through enhancing coworkers' and/or managerial productivity (Podsakoff et al., 2009; Podsakoff \& MacKenzie, 1997). Relative to the studies on unit/organization-level outcomes of OCB, there are a large number of studies examining individual-level outcomes of OCB. Generally, OCB has been shown to be positively related to supervisory performance evaluation and reward/promotion decisions (Grant \& Mayer, 2009; Podsakoff et al., 2009). Researchers have argued that the reciprocity norm may explain why OCB can lead to favorable individual-level outcomes (Podsakoff et al., 2009). In addition to the reciprocity norm, researchers proposed another possible explanation for favorable individual-level outcomes of OCB. That is, when a manager evaluates an employee's performance or makes a decision on reward/promotion, the manager tends to search for information that can distinguish the focal employee from other employees (DeNisi, Cafferty, \& Meglino, 1984). Since OCB is discretionary, employees' engagement in OCB is a piece of information enabling managers to distinguish good citizens from average or poor citizens (DeNisi et al., 1984; Podsakoff et al., 2000).

Surprisingly, OCB has been recently observed to also lead to undesirable individual outcomes (Bolino, Hsiung, Harvey, \& LePine, 2015; Yam, Klotz, He, \& Reynolds, 2017). For example, citizenship fatigue is more likely to result when employees engaging in OCB do not feel supported by organizations (Bolino et al., 2015). Also, researchers observed when employees feel compelled to engage in OCB, their engagement in OCB may lead to interpersonal and organizational deviance behaviors, such as making fun of others at work and taking property from work without permission (Yam et al., 2017). When employees feel compelled to engage in OCB, the positive effect of OCB on deviance behavior is transmitted 
through employees' increased psychological entitlement (Yam et al., 2017). Some researchers have explained that employees may feel morally licensed to act unethically after engaging in OCB (Klotz \& Bolino, 2013; Yam et al., 2017). Other researchers have suggested that engaging in OCB may lead to resource depletion, and exhausted employees may not regulate their behaviors very well. In turn, they tend to exhibit undesirable individual behaviors, such as complaining and becoming querulous (Bolino \& Klotz, 2015; Klotz \& Bolino, 2013).

\section{Two Types of OCB}

As the OCB literature has evolved, two types of OCB have been distinguished by researchers: affiliative OCB and challenging OCB. Affiliative OCB refers to interpersonal, cooperative behavior (Podsakoff, MacKenzie, Paine, \& Bachrach, 2000) such as working extra hours, taking on more assignments, and going out of one's way to facilitate others' completion of assignments. As Van Dyne and LePine (1998) argued, affiliative OCB is present-oriented and emphasizes harmony. It aims to preserve the currently established procedures and build interpersonal relationships. Unlike affiliative OCB focusing on supporting the status quo by helping others, showing compliance or being good citizens (Organ, 1988), challenging OCB aims to change the status quo by pointing out insufficiencies of existing work procedures or management practice, suggesting ideas for improvement, and applying creative methods in one's job (Burris, 2012; Choi, 2007; Van Dyne \& LePine, 1998). Challenging OCB is future-oriented and emphasizes change. It aims to suggest or introduce change to reach a more ideal state.

Although Organ's (1998) definition of OCB did not explicitly exclude challenging OCB, early research on OCB has primarily focused on affiliative OCB, such as helping and compliance (Bateman \& Organ, 1983; Borman \& Motowidlo, 1997; Williams \& Anderson, 1991). The exclusion of challenging OCB could be exemplified by the five dimensions of OCB: helping, 
compliance, sportsmanship, courtesy, and civic virtue (Organ, 1988), which are all affiliative OCBs. For example, sportsmanship refers to an employee's "willingness to tolerate the inevitable inconvenience and imposition of work without complaining” (Organ, 1990, p. 96). Civic virtue reflects an employees' willingness to actively participate in his/her organization's governance (Organ, 1990; Podsakoff et al., 2000). In addition, Williams and Anderson (1991) distinguished two broad categories of OCB based on targets (organizations or individuals) who benefit from employees' OCB: OCB-O (organizations) and OCB-I (individuals). The typical examples of OCB-O are "gives advance notice when unable to come to work, [and] adheres to informal rules devised to maintain order" (Williams \& Anderson, 1991, p. 601-602) and examples of OCB-I are "helps others who have been absent, [and] takes a personal interest in other employees" (Williams \& Anderson, 1991, p. 602). Scholars have explained that the focus on affiliative forms of OCB is likely associated with traditional expectations placed on employees: show loyalty, support managerial decisions, and follow instructions and orders (Bindl \& Parker, 2010; Choi, 2007; Frese, 2008).

As organizations increasingly acknowledge the importance of innovation and motivating employees via empowerment (Campbell, 2000; Crant, 2000), more forms of OCB have been receiving scholarly attention and interest (Bindl \&Parker, 2010; Podsakoff et al., 2000; Van Dyne \& LePine, 1998). For example, Podsakoff and colleagues (2000) extended the five dimensions of OCB by incorporating another two dimensions: personal initiative and selfdevelopment. Personal initiative refers to persisting with extra enthusiasm and efforts to accomplish one's job and applying creative methods to improve job performance (Podsakoff et al., 2000). Self-development refers to learning continuously, such as seeking out training opportunities to improve one's knowledge and skills, enabling employees to better contribute to 
their organizations (Podsakoff et al., 2000). In addition, challenging OCB, such as voice behavior and taking charge, has been increasingly studied (Burris, 2012; Burris et al., 2017; Detert et al., 2013).

Researchers have argued that both affiliative and challenging OCBs have a shared intention to benefit an organization and/or the people in the organization, but factors driving the two behaviors are different (Katz, 1964; Van Dyne \& LePine, 1998). Particularly, affiliative OCB derives from employees' satisfaction with the status quo: their current jobs, interpersonal relationships among employees, compensation policies, work procedures, management practices, and so on. According to social exchange theory, when employees feel satisfied with the status quo, they are motivated to reciprocate by going the extra mile to exhibit supportive behavior (Van Dyne, Graham, \& Dienesch, 1994). Research has shown that favorable attitudes such as satisfaction with the leader and the job, commitment, and fairness perceptions predict affiliative OCB (Podsakoff et al., 2000). In contrast, challenging OCB originates from employees' dissatisfaction with the status quo. Hence, employees are driven to improve existing conditions by making constructive suggestions to improve an organization's functioning and promote its adaptation (Crant, 2000; Fuller \& Marler, 2009; Parker, \& Collins, 2010; Seibert, Kraimer, \& Crant, 2001). Scholars further argued, even though employees are dissatisfied with specific conditions or procedures, they may still hold overall favorable attitudes toward the job, the leader, or the organization. Otherwise, employees are likely to be silent, withdrawn, or even choose to exit (Burris et al., 2008; Farrell, 1983; Hirschman, 1970; Rusbult, Farrell, Rogers, \& Mainous, 1988; Van Dyne \& LePine, 1998). Employees who engage in challenging OCB such as voice behavior may have an adequate level of loyalty, psychological attachment, or job satisfaction, but they believe the situation can be improved. Hence, challenging OCB is driven 
by employee dissatisfaction with specific rules or policies, but it does not necessarily mean employees have overall unfavorable job attitudes (Van Dyne \& LePine, 1998).

In addition to different driving factors, affiliative and challenging OCBs also may benefit an organization in different ways. Affiliative OCB promotes interpersonal facilitation and cooperation, which can promote organizational performance and functioning (Podsakoff et al., 2009). Challenging OCB behavior may contribute to an organization by facilitating its continuous improvement and adaptation to changing environments (Crant, 2000; Detert \& Burris, 2007). Researchers have further argued that people may realize an organization could benefit potentially from challenging OCB. However, this type of behavior is generally unwelcomed because people tend to see such behavior as "rocking the boat" and threatening (Burris, 2012; Morrison \& Milliken, 2000; Rank, Pace, \& Frese, 2004). In contrast to affiliative OCB, challenging OCB is risky for employees due to its change-oriented nature (Burris, 2012; Fast et al., 2014; Morrison \& Milliken, 2000).

As mentioned earlier, voice behavior is conceptualized as a challenging OCB and proactive behavior (Van Dyne \& LePine, 1998). In the next section, I will discuss proactive behavior, followed by a comparison of the similarities and differences between OCB and proactive behavior.

\section{PROACTIVE BEHAVIOR}

\section{What is Proactive Behavior?}

Bindl and Parker (2010) define proactive behavior as:

Self-directed and future-focused action in an organization in which the individual aims to bring about change, including change to the situation (e.g., introducing new work 
methods, influencing organizational strategy) and/or change within him or herself (e.g., learning new skills to cope with future demands) (p. 568).

Proactive behavior has been observed to have favorable individual-level and team-level outcomes (Bindl \& Parker, 2010; Crant, 2000). Employees’ proactive behaviors have increasingly attracted scholarly attention and interest (Bindl \& Parker, 2010; Crant, 2000; Parker \& Collins, 2010) because organizations increasingly emphasize the importance of innovation and motivating employees through empowerment (Campbell, 2000; Crant, 2000).

\section{Why do Employees Engage in Proactive Behavior?}

The factors impacting employees' display of proactive behaviors can be organized into three categories: dispositional, motivational, and situational factors. The dispositional factor that is most often discussed as a predictor of proactive behavior is proactive personality (Parker \& Collins, 2010; Seibert et al., 2001). As mentioned earlier, proactive personality is defined as a personality trait associated with being relatively unconstrained by situational forces and prone to effecting change to improve the current situation and/or oneself (Bateman \& Crant, 1993).

Motivational factors also may affect employees' display of proactive behavior (Parker \& Bindl, 2010). This is because engaging in proactive behavior, such as effecting change, is usually a deliberate decision process in which employees evaluate whether they are capable of enacting change successfully (Parker \& Bindl, 2010). As Parker and Bindl (2010) argued, employees’ capability of enacting change successfully maps onto expectancy theory (e.g., the link from effort to performance); that is, when one is more capable of enacting a behavior effectively, he or she is more motivated to exhibit this behavior. Indeed, it has been observed that employee selfefficacy is positively related to their proactive behaviors (Morrison \& Phelps, 1999; Ohly \& Fritz, 2007; Parker \& Collins, 2010). Moreover, as scholars noted, "Even if people are certain 
they can do a task, they may have no compelling reason to do it" (Eccles \& Wigfield, 2002, p. 112). Individuals' aspiration for achieving a certain goal also has been observed to affect their proactive behaviors. For example, employees who desire more useful information tend to engage in more feedback seeking behavior (Tuckey, Brewer, \& Williamson, 2002). Employees who feel more obligated to bring change to the workplace have been observed to engage in more proactive behavior (Fuller, Marler, \& Hester, 2006; Parker \& Collins, 2010; Parker, Williams, \& Turner, 2006).

Situational factors, such as job design and leadership style, also have been argued to affect employees' engagement in proactive behavior. Work design giving employees a sense of empowerment has been argued to contribute to employees' proactive behavior (Bindl \& Parker, 2010). For instance, job autonomy has been observed to be positively associated with employees' display of proactive behavior (Frese, Garst, \& Fay, 2007; Hornung \& Rousseau, 2007; Parker et al., 2006).

Leadership style is another important situational factor impacting employee proactive behavior. Participative leadership, emphasizing employees' contributions and involvement in decision making, has been observed to be positively related to employee proactive behavior (Rank, Carsten, Unger, \& Spector, 2007). Similarly, transformational leadership, which encourages employees to go beyond standard expectations and identify change opportunities, has been shown to be positively associated with employee proactive behavior (Rank, Nelson, Allen, $\& \mathrm{Xu}, 2009)$. The quality of the dyadic relationship between a leader and an employee, as exemplified in leader-member-exchange theory also has been observed to positively affect employee proactive behavior (Janssen, Van Yperen, \& West, 2004). High LMX tends to promote 
a climate of trust between leaders and employees, enabling employees to have the courage to exhibit proactive behavior (Bindl \& Parker, 2000; Janssen et al., 2004).

\section{What are the Consequences of Proactive Behavior?}

Proactive behavior has favorable effects on individual-level and team-level outcomes (Crant, 2000; Bindl \& Parker, 2000). Employees' proactive behavior has been observed to be positively related to job performance rated by supervisors (Grant, Parker \& Collins, 2009) and career success, such as employees' self-reported career satisfaction and actual promotions at work (Seibert et al., 2001). Researchers have explained that the favorable outcomes of proactive behavior may be the result of a better fit between employees and the job/situation (Bindl \& Parker, 2010; Parker \& Collins, 2010). A better fit can be achieved by proactive behaviors, such as actively seeking feedback from others, communicating with others about task assignments and role expectations, and detecting opportunities for improvement (Bindl \& Parker, 2010; Parker \& Collins, 2010). In addition to its favorable effects on individual-level outcomes, team-level proactive behavior has been shown to be positively associated with team-level outcomes (Hyatt \& Ruddy, 1997; Kirkman \& Rosen, 1999). For instance, team proactive behavior rated by supervisors has been observed to be positively related to supervisor-rated team productivity and the aggregated job satisfaction rated by team members (Kirkman \& Rosen, 1999).

As researchers have increasingly acknowledged the importance of employee proactive behavior, scholars also have suggested that employee proactive behavior may backfire (Grant \& Ashford, 2008; Frese \& Fay, 2001; Bindl \& Parker, 2010). As Grant and Ashford (2008) highlighted, "proactive behavior involves expending additional effort, challenging the status quo and disrupting or deviating from assigned tasks, prescribed roles, reified norms, accepted practices, and existing routines, researchers should expect to find mixed effects and unintended 
consequences" (p. 24). Similarly, researchers have suggested that employee proactive behavior may be considered an attempt to rock the boat, leading to negative responses from coworkers and supervisors (Frese \& Fay, 2001). Indeed, it has been observed that employee proactive behavior, such as voice behavior, may result in low performance ratings (Burris, 2012; Howell et al., 2015). Thus, researchers appeal for studies examining conditions under which the effects of proactive behaviors may vary (Bindl \& Parker, 2010).

\section{COMPARISON OF OCB AND PROACTIVE BEHAVIOR}

The early OCB literature and proactive behavior literature have been considered as two different research areas (Crant, 2000; Podsakoff et al., 2000). The two areas, OCB and proactive behavior literatures, did not intersect until the conceptualization of OCB was extended by including challenging OCB (Choi, 2007). Both challenging OCB and proactive behavior emphasize that employees' intentions are to challenge the status quo and bring in constructive change (Bindl \&Parker, 2010; Crant, 2000). Challenging OCB has been considered to be proactive behavior (Morrison, 2014; Van Dyne \& LePine, 1998) because such behavior is futurefocused and change-oriented. However, not all proactive behaviors are considered to be OCBs. As conceptualized, OCB aims to benefit people or an organization whereas proactive behavior can be beneficial for either others, oneself, or both. The typical examples of a proactive behavior benefiting oneself are feedback seeking (Ashford, 1986; Ashford, Blatt, \& Van de Walle, 2003) and active attempts to manage and promote one's career (Seibert et al., 2001).

Challenging OCB and proactive behavior aim to challenge established practices and procedures (Parker \& Collins, 2010). Employees' proactive personality has been widely observed to be a predictor of both challenging OCB and proactive behavior (Bindl \&Parker, 2000; Seibert et al., 2001). In addition, challenging OCB and proactive behavior are risky 
because they are threatening and challenging, and thus may be resented by others (Fast et al., 2014; Howell et al., 2015). It has been observed that employees' psychological safety and selfefficacy can predict their engagement in these two behaviors (Edmondson, 1999; Parker et al., 2006). Situational factors promoting employees' psychological safety and self-efficacy perceptions have been observed to be positively associated with employees' engagement in challenging OCB and proactive behavior (Den Hartog \& Belschak, 2012; Detert \& Burris, 2007; Liu et al., 2010).

Organizational citizenship behavior (OCB) and proactive behavior have favorable effects on unit/organization-level outcomes (Kirkman \& Rosen, 1999; Podsakoff et al., 2000). Researchers have argued that OCB and proactive behavior may benefit an organization through facilitating others' work and/or improving the current work procedures (Organ, 1988; Van Dyne \& LePine, 1998). Employees’ proactive behavior also may benefit an organization through promoting employees' fit with the job/environment (Erdogan \& Bauer, 2005). In contrast to the favorable effects on unit/organization-level outcomes, it has been observed that challenging OCB and proactive behavior can lead to mixed individual-level outcomes and people's differential reactions. On one hand, managers may appreciate these discretionary behaviors by giving favorable performance evaluations or rewards (Howell et al., 2015; Podsakoff et al., 2000). On the other hand, people may consider these discretionary behaviors as disturbing, threatening, and/or self-promoting (Grant \& Ashford, 2008). Researchers also have provided an alternative explanation of the adverse effects of OCB and proactive behavior. That is, employees' engagement in these behaviors tends to consume additional resources, detracting employees from their own tasks and self-regulation (Bolino \& Klotz, 2015; Detert \& Burris, 2007; Klotz \& Bolino, 2013). 
Due to the mixed findings on people's reactions to employees' challenging OCB and proactive behavior (Grant \& Ashford, 2008; Howell et al., 2015), scholars have called for future research to examine conditions under which challenging OCB and proactive behavior will lead to favorable or adverse outcomes, such as observers' reactions toward these behaviors (Bindl \& Parker, 2010; Grant \& Ashford, 2008; Yam et al., 2017). To this end, this study aims to examine two conditions, employee political skills and supervisor perceived instrumentality of implementing suggested changes, under which employee voice behavior may lead to different supervisors' reactions via supervisors' different motive attributions. 


\section{CHAPTER III. HYPOTHESIS DEVELOPMENT}

The study is designed to understand when and why supervisors endorse and implement employee voice behavior. I argue that employees' political skills, supervisors' motive attributions for employee voice behavior, and supervisors' perceived instrumentality of suggested changes play important roles in supervisors' reactions to employee voice behavior (see Figure 1 for the conceptual model).

It is important to study when and why supervisors will endorse and implement suggestions brought up by employees. This is because supervisors' reactions to employee voice behavior affect employees' future engagement in voice behavior and commitment to the organization (Detert \& Burris, 2007; Liu et al., 2010; McClean et al., 2013). Supervisors' reactions to employee voice behavior also may affect whether suggested changes will be implemented and in turn whether organizations will benefit from suggested changes.

This study will focus on two types of supervisors' reactions to employee voice: a) voice endorsement and b) voice implementation. Voice endorsement refers to the extent to which supervisors believe suggested changes have potential value and are willing to take employees' suggestions to higher-level leaders (Burris, 2012). Voice implementation refers to the extent to which supervisors spend effort and resources on implementing suggestions brought up by employees (Baer, 2012). As reviewed earlier, the extant voice behavior literature has focused on two types of supervisors' reactions to voice behavior: voice endorsement and employees' overall performance ratings (Burris, 2012; Burris et al., 2017; Howell et al., 2015). This study aims to focus on voice endorsement and voice implementation because these two constructs represent the extent to which supervisors are willing to and actually carry out employees' suggestions. 
Researchers have argued that employee voice behavior may be appreciated by supervisors and higher-ups in organizations because employees take the initiative to detect potential problems and share their suggestions for improvement (Burris, 2012; Van Dyne \& LePine, 1998). Indeed, the voice behavior literature has revealed that supervisors may react favorably to employee voice behavior by giving high performance ratings (Howell et al., 2015). However, supervisors also may react negatively to employee voice behavior by feeling resentful or giving low performance ratings (Burris, 2012; Fast et al., 2014). Thus, researchers have been seeking answers to why supervisors react differently to employee voice behavior (Burris, 2012; Howell et al., 2015; Whiting, Maynes, Podsakoff, \& Podsakoff, 2012).

\section{Supervisors' Motive Attributions for Employee Voice Behavior}

The existing voice behavior literature has advanced our understanding of supervisors' reactions to employee voice behavior. For instance, it has been observed that supervisors' managerial self-efficacy, ego-threat, and perceived employees' loyalty explain supervisors' reactions to employee voice behavior (Burris, 2012; Fast et al., 2014). I argue supervisors' motive attributions for employee voice behavior as additional mechanisms for explaining supervisors' reactions to employee voice behavior, as detailed below.

First, supervisors' motive attributions are likely to form when employees engage in voice behavior. Voice behavior may not be formally rewarded and may be considered a risky and costly behavior (Burris, 2012; Tangirala \& Ramanujam, 2012). When actors engage in discretionary and risky or costly behaviors, perceivers seek to understand why the actors engage in these behaviors (Bowler et al., 2010; Pyszczynski \& Greenberg, 1981). For example, helpseekers have been observed to be more likely to make attributions for help-givers' behaviors when these helping behaviors involve greater personal cost to help-givers (Pyszczynski \& 
Greenberg, 1981). Expectancy theory (Vroom, 1964) and the theory of planned behavior (Ajzen, 1991; 2002) suggest people are more motivated to exhibit a behavior resulting in greater desirable outcomes. It is less likely for help-seekers to expect others to offer help at greater cost. If people decide to help others at great personal cost, this decision usually contradicts helpseekers' expectation. Under this circumstance, help-seekers tend to figure out why help-givers are willing to do the favor. Similarly, I expect supervisors' motive attributions may be triggered when employees engage in voice behavior, a non-required and risky behavior.

Second, perceivers tend to make motive attributions for actors' behaviors when perceivers and actors hold opposing opinions (Reeder, Pryor, Wohl, \& Griswell, 2005) because researchers have argued that disagreement may lead people to speculate about why others have divergent views (Reeder et al., 2005). Although employee voice behavior may not necessarily challenge supervisors personally, it at least goes against the current work procedures which are usually under the charge of supervisors (Detert \& Trevino, 2010). Therefore, supervisors' motive attributions are likely to be triggered when employees express disagreement with the current management practice.

To what motives do supervisors attribute employee voice behavior? Prosocial and selfserving motives have been identified in the OCB literature (Rioux \& Penner, 2001). The two motives correspond to the two basic needs of human beings: getting along and getting ahead (Hogan, Jones, \& Cheek, 1985; Hogan \& Shelton, 1998) It is noteworthy that prosocial and selfserving motives have been observed to be two distinct constructs instead of two ends of a continuum (Grant \& Mayer, 2009; Rioux \& Penner, 2001). While some researchers have observed prosocial motives and self-serving motives to be slightly positively correlated (Rioux \& Penner, 2001), other researchers have observed the two motives to be uncorrelated (Halbesleben 
et al., 2010). Scholars have proposed that employee voice behavior may be a dual-motive behavior (Klaas et al., 2012; Morrison, 2014). As Morrison (2014) noted, "Voice is primarily prosocial, but this does not mean that it lacks benefits for the actor, nor that the actor will fail to consider those benefits. It is, therefore, reasonable to assume that when employees are deciding whether to engage in voice, they may consider not just how this behavior could lead to organizational or unit-level improvement, but also how it could potentially advance their own interests" (p. 184). In addition, researchers have observed supervisors may be able to detect motives underlying employees’ helping behavior (Donia, Johns, \& Raja, 2016). Thus, supervisors may attribute employee voice behavior as both prosocial and self-serving. Interactions between Employee Voice Behavior and Political Skills on Supervisors' Motive Attributions

I argue the extent to which supervisors attribute employee voice behavior as prosocial and self-serving depends on the strength of employees' political skills. Political skill is conceptualized as a social effectiveness construct and is defined as "the ability to effectively understand others at work, and to use such knowledge to influence others to act in ways that enhance one's personal and/or organizational objectives" (Ferris, Treadway, Kolodinsky, Hochwarter, Kacmar, Douglas, \& Frink, 2005, p. 127). Researchers have argued that people differ in their levels of social effectiveness, and social effectiveness influences how people express themselves behaviorally across different situations (Gangestad \& Snyder, 2000; Hogan \& Shelton, 1998). Specifically, people with higher levels of social effectiveness are more likely to attend to situational or social cues to regulate their behaviors, and they are more concerned about the situational appropriateness of their behaviors. Comparatively, people with lower levels of social effectiveness are less likely to attend to situational or social cues, and thus exhibit 
behaviors more reflective of their dispositions. Thus, individuals' social effectiveness is one explanation for behavioral inconsistency across situations, and individuals higher in social effectiveness are more likely to exhibit situationally appropriate or desirable behaviors (Gangestad \& Snyder, 2000; Hogan \& Shelton, 1998).

Political skill is a widely examined construct in organizational settings (Ferris et al., 2005). It has been observed to be a stronger predictor of performance evaluation, relative to other social effectiveness constructs, such as self-monitoring and emotional intelligence (Semadar et al., 2006). Also, political skill has significant incremental validity in predicting performance evaluation scores over other social effectiveness constructs (Semadar et al., 2006), general mental ability, and Big Five personality characteristics (Munyon et al., 2015). Politically skilled employees can accurately comprehend interpersonal interactions, and adapt and calibrate their behaviors in accordance with social cues (Ferris et al., 2005). Also, politically skilled employees can present themselves in a socially desirable way and produce desired change in others (Ferris et al., 2005; Treadway, Ferris, Duke, Adams, \& Thatcher, 2007). Political skills enable employees to convey genuine and trustworthy images and develop central positions in their social networks (Blass \& Ferris, 2007; Ferris et al., 2005; Ferris, Treadway, Perrewe, Brouer, Douglas, \& Lux, 2007).

Employee voice behavior and political skills may interact to affect supervisors' motive attributions for employee voice behavior, such that as political skills and voice behavior increase, supervisors may be more likely to attribute employees' voice behavior to a prosocial motive and less likely to attribute this behavior to a self-serving motive.

First, politically skilled employees may know how to express their concerns and make suggestions by using appropriate language, tone of voice, and facial expression to make them 
look polite, sincere, and trustworthy (Ferris et al., 2015). This is because politically skilled employees have a high level of awareness of themselves, others, and social interactions (Ferris et al., 2005; Munyon et al., 2015). They are capable of adjusting their behavior based on social cues (e.g., others' facial expressions or emotions) to influence others effectively or to be perceived favorably (Muynon et al., 2015). As Ferris et al. (2007, p. 307) noted, politically skilled employees are able to, "appear genuine and authentic in their behavior, with no ulterior motive." People have been observed to interpret challenging information more favorably when challenging information is provided by people who look sincere and trustworthy (Steelman \& Rutkowski, 2004). Conversely, less politically skilled employees tend to express their disagreement and suggestions in a less socially desirable way since they lack social astuteness and apparent sincerity compared to politically skilled employees (Ferris et al., 2005). Supervisors may interpret less politically skilled employees' voice behavior as complaining and speaking for themselves.

Furthermore, researchers have observed that the frequency of communications between employees and supervisors will accentuate supervisors' perceptions of and reactions to employees (Kacmar, Witt, Zivnuska, \& Gully, 2003). For example, it has been observed that at high levels of LMX, employees who frequently communicate with supervisors tend to receive higher performance ratings compared to employees who less frequently communicate with supervisors. In contrast, at low levels of LMX, employees who frequently communicate with supervisors tend to receive lower performance ratings compared to employees who less frequently communicate with supervisors (Kacmar et al., 2003). As researchers have argued (Kacmar et al., 2003), the impressions employees make on their supervisors will be amplified as employees have more frequent communications with their supervisors. Thus, I argue as 
employees have greater political skills and more frequently communicate with supervisors to express concerns and suggestions, supervisors may be more likely to perceive this frequent voice behavior as caring about people and/or the organization, and less likely to interpret the frequent voice behavior as disloyal and calculating. On the contrary, as less politically skilled employees engage in voice behavior more frequently, their supervisors may be more likely to perceive this frequent voice behavior as calculating or self-serving, and less likely to interpret this frequent voice behavior as loyal and caring about people and/or the organization.

Second, political skills enable employees to have a good understanding of what is important to other people and the organization (Jawahar, Meurs, Ferris, \& Hochwarter, 2008; Munyon et al., 2015). They tend to understand different people's perspectives and needs, instead of sticking with their own perspective (Ferris et al., 2005; Ferris, Treadway, Perrewe, Brouer, Douglas, \& Lux, 2007; Gangestad \& Snyder, 2000). This is because employees with great political skills are able to develop central positions in their social networks, and are well connected with people (Ferris et al., 2005). They have access to a large amount of information and opinions due to their advantageous position in the social network (Cullen, Gerbasi, \& Chrobot-Mason, 2018; Ferris et al., 2007; Munyon et al., 2015). A politically skilled employee may express concerns and make suggestions incorporating others' concerns and needs, whereas a less politically skilled employee may express a concern and make a recommendation merely from his/her own perspective, failing to consider others' needs and preferences. Hence, as employees have greater political skills and share more ideas for change which may accommodate more people's needs, employee voice behavior may be more likely to be perceived as prosocial, and less likely to be perceived as self-serving. In contrast, less politically skilled employees may not have access to a large amount of information, such as other people's concerns and 
preferences due to their lack of ability to develop central positions in their social networks (Cullen et al., 2018; Ferris et al., 2007). When less politically skilled employees make suggestions to their supervisors, they may fail to take others' opinions into consideration or address others' concerns. Thus, as less politically skilled employees more frequently engage in voice behavior, their supervisors may be more likely to attribute the frequent voice behavior to a self-serving motive, and less likely to interpret the frequent voice behavior as prosocial.

Third, politically skilled people have been observed to develop good reputations (Blickle et al., 2011; Munyon et al., 2015; Smith, Plowman, Duchon, \& Quinn, 2009; Zinko et al., 2012). This may be because they are good at building their public images through their situationally appropriate behaviors or effective influence attempts, and they are in the central positions in their networks through which their favorable images spread easily (Liu, Ferris, Zinko, Perrewe, Weitz, $\& \mathrm{Xu}, 2007)$. Reputation is defined as a "complex combination of salient personal characteristics and accomplishments, demonstrated behavior, and intended images presented over some period of time” (Ferris, Blass, Douglas, Kolodinsky, \& Treadway, 2003, p. 213). Reputation has been argued to be a collective perception by others and often forms based on a consistent pattern of past behavior (Ching, Holsapple, \& Whinston, 1992). Reputation takes both time and effort to build, and it is easily jeopardized by inconsistent behaviors. Individuals tend to behave in a way that is consistent with their reputations (Baumeister, 1982). Thus, an actor's reputation often is used by observers to understand the actor's current behavior and predict his/her future behavior (Blickle et al., 2011; Whitmeyer, 2000). Reputation may lead to a halo effect. Halo effect refers to a tendency that people's global evaluation of a person will influence their perceptions of specific traits and behaviors of the person (Nisbett \& Wilson, 1977). An actor's good reputation 
has been suggested to give the actor the benefit of observers' favorable interpretation of his/her specific behaviors (Zinko, Ferris, Blass, \& Laird, 2007).

Taken together, I contend:

Hypothesis 1: Employees' voice behavior and political skills interactively affect supervisors' prosocial motive attribution such that the relationship between employee voice behavior and supervisors' prosocial motive attribution will become positively stronger as employees' political skills increase.

Hypothesis 2: Employees' voice behavior and political skills interactively affect supervisors' self-serving motive attribution, such that the relationship between employee voice behavior and supervisors' self-serving motive attribution will become positively stronger as employees' political skills decrease.

\section{Supervisors' Perceived Instrumentality as the Moderator of the Relationships between}

\section{Their Motive Attributions and Voice Endorsement}

Supervisors' motive attributions for employee voice behavior may play important roles in their reactions to voice behavior (Halbesleben et al., 2010; Weiner, 1980). Specifically, supervisors may be more likely to endorse employees' suggestions driven by more prosocial concerns compared to suggested change driven by self-serving concerns. As Yukl (1982) argued, the amount of social status accorded a leader is proportionate to the leader's contribution to the team and team members. Leaders may gain or lose their status, depending on whether they are able to address their members' concerns and achieve team goals (Yukl, 1982; 1989). Thus, it may be more likely for supervisors to spend time and effort addressing problems that will affect members' common benefits or team goals. By contrast, supervisors may be less likely to endorse suggested changes driven by employees' self-interest concerns. Supervisors may not want to 
encourage employees to pursue self-interest. Merely pursuing self-interest may result in conflicts with others' welfare and interests due to the finite resources in organizations (Ferris \& Judge, 1991; Narayanan \& Fahey, 1982; Pfeffer, 2010) and may lead teams and organizations into a divisive state (Chang, Rosen, \& Levy, 2009). In short, prosocial motive attribution for employee voice behavior may have a positive effect on supervisors' voice endorsement, whereas selfserving motive attribution may have a negative effect on supervisors' voice endorsement.

Nevertheless, motive attributions may not be a sufficient reason for supervisors to endorse and implement employees' suggestions. Any effort spent on endorsing and implementing suggested changes may be risky and may lead to undesirable consequences (Janssen et al., 2004). For example, it has been observed that introducing change at work may lead to resource cost, disharmony, and conflicts among colleagues who are affected by a suggested change (Baer, 2012; Janssen, 2003; Janssen et al., 2004). Thus, the effects of supervisors' motive attributions on their reactions may vary depending on the extent to which supervisors perceive employees' suggested changes can lead to desirable outcomes.

Supervisors' perceived instrumentality of implementing employees' suggestions is defined as the extent to which supervisors expect positive outcomes to be associated with their efforts of implementing employees' ideas (Baer, 2012). When supervisors believe the suggested changes are instrumental in achieving more desirable outcomes, they may have greater motivation to endorse them (Ajzen, 1991; Vroom, 1964). Indeed, researchers have observed that individuals are concerned about perceived desirable outcomes, such as expected performance improvement and personal image gains, when they decide whether to put effort in introducing change (Yuan \& Woodman, 2010). Also, individuals are more likely to put their ideas into reality when they believe these ideas can result in more favorable outcomes (Baer, 2012). 
Haworth and Levy (2001) observed that the positive effect of procedural justice on employees' OCB was strengthened when employees perceived OCB resulted in positive outcomes. Thus, supervisors' perceived instrumentality of suggested changes may act as an impetus, fueling supervisors' motivation to endorse employees' recommendations driven by prosocial concerns.

On the other side, supervisors may be less likely to refuse suggestions driven by employees' self-serving concerns when supervisors can foresee more desirable outcomes of a suggested change. In this case, a win-win situation is created (Ashford \& Black, 1996). When employees' interests, to some extent, are aligned with supervisors' and/or organizations' interests, supervisors might be unlikely to turn down employees' suggestions. For example, employees' job change negotiation behavior has been argued to contribute to employees' performance, person-job fit, and organizational socialization (Ashford \& Black, 1996; Gruman, Saks, \& Zweig, 2006; Parker \& Bindl, 2010). When employees suggest supervisors change task assignments to better fit employees' expertise and skills (e.g., job change negotiation, Ashford \& Black, 1996), supervisors might be unlikely to refuse this suggestion if they can anticipate the favorable consequences to both employees and organizations (e.g., employees' performance and commitment). In sum, anticipated desirable outcomes may inhibit supervisors' tendency to refuse employees' suggestions driven by self-serving concerns.

Thus, I contend:

Hypothesis 3: Supervisors' perceived instrumentality of suggested changes will moderate the positive effect of prosocial motive attribution on voice endorsement, such that the positive effect will be strengthened as perceived instrumentality increases. 
Hypothesis 4: Supervisors' perceived instrumentality of suggested changes will moderate the negative effect of self-serving motive attribution on voice endorsement, such that the negative effect will be weakened as perceived instrumentality increases.

Supervisors' voice endorsement represents the extent to which supervisors believe suggested changes have potential value and are willing to take employees' suggestions to higherlevel leaders (Burris, 2012). As Vroom (1964) and Ajzen (1991; 2002) suggested, when a person can foresee the potential value of enacting a behavior, this person will be more likely to engage in this behavior. When supervisors believe suggested changes have potential value, they may be likely to allocate resources to implement the suggested changes. It has been observed that individuals are likely to introduce innovative changes to the workplace when they expect these innovative changes will lead to positive performance outcomes (Yuan \& Woodman, 2010). Also, as the theory of planned behavior (Ajzen, 1991; 2002) suggested, people' behavioral intention is predictive of people's actual engagement in such behavior. Similarly, Burris (2012) has argued that supervisors' endorsement for suggested changes is an important precursor to making changes in organizational routines or processes. Thus, I contend:

Hypothesis 5: Supervisors' voice endorsement will be positively related to their voice implementation.

\section{The Integrated Research Model}

Thus far, I have developed hypotheses for the interactive effects of employee voice behavior and political skills on supervisors' motive attributions (Hypothesis 1 and 2), the moderating effects of supervisors' perceived instrumentality on the relationships between supervisors' motive attributions and their voice endorsement (Hypothesis 3 and 4), and the direct effect of voice endorsement on voice implementation (Hypothesis 5). Taken together, this study 
will examine a dual-stage moderated mediation model (Edwards \& Lambert, 2007; Preacher, Rucker, \& Hayes, 2007). I argue for the following integrative hypotheses for the dual-stage moderated mediation model:

Hypothesis 6: The indirect relationship between employee voice behavior and supervisors' voice implementation via supervisors' prosocial motive attribution and voice endorsement will be moderated by employees' political skills and supervisors' perceived instrumentality at the first and second stages, respectively.

Hypothesis 7: The indirect relationship between employee voice behavior and supervisors' voice implementation via supervisors' self-serving motive attribution and voice endorsement will be moderated by employees' political skills and supervisors' perceived instrumentality at the first and second stages, respectively. 


\section{CHAPTER IV. METHODS}

\section{Sample}

This study was approved by the West Virginia University Institutional Review Board (\#1812402257). The sample in this study consists of 291 employee-supervisor dyads from 12 organizations in China. The number of employees was 291 and the number of supervisors was 100. Among 100 supervisors, 91 supervisors had three direct reports and 9 supervisors had two direct reports, resulting in 291 employees in total. These organizations operated in a variety of industries including software engineering and IT, biomedical, energy engineering, chain medicine, and auto sales.

I obtained approval from the executives of these organizations to conduct this study at their workplaces. Two briefing sessions were conducted to introduce the procedure of this study. One briefing session was intended for employees only and the other briefing session was intended for their supervisors. They were told that their participation was totally voluntary and if they agreed to participate, there would be one survey for employees and three-waves of surveys for supervisors with a one-month interval between each survey. They were also told that they were free to withdraw at any time from this study without any penalty and they would be paid CNY 15 (around \$2.50 U.S.) for the completion of each survey as a small token for their spent time. They were assured that all the data would be kept confidential and analyzed in an aggregate form. In total, 300 employees and 100 supervisors attended the briefing sessions. Of 300 employees, 291 employees agreed to participate in this study. All the supervisors who attended the briefing session agreed to participate in this study. The employee response rate in Wave 1 was $97 \%$ and the supervisor response rate in Wave 1 was 100\%. The supervisor response rate was $100 \%$ in Wave 2 and Wave 3 . The names of employees to be rated by supervisors were 
indicated in each wave supervisor survey. This way, supervisors were clear about whom they were rating. Of the 291 employee participants, 32\% were male (one missing value on gender); the average age was $34.57(\mathrm{SD}=7.58)$; the average tenure with the organization was 7.34 years $(\mathrm{SD}=6.96)$; and the average tenure with the supervisor was 4.57 years $(\mathrm{SD}=4.20)$. Of the 291 employee participants, 276 employees provided education background information. Among those who provided this information, the majority (64\%) have a bachelor degree, and $29 \%$ have a professional certificate. Among the 100 supervisor participants, 31\% were male; the average age was 41.29 years old $(\mathrm{SD}=6.69)$; the average tenure with the organization was 12.53 years $(\mathrm{SD}=$ 9.55). Of the 100 supervisor participants, 97 supervisors provided education background information. Among those who provided this information, $73 \%$ had a bachelor degree, and $15 \%$ had a master degree.

\section{Power Analysis and Study Design}

Before data collection, I conducted a power analysis to estimate the sample size of employees needed for testing a two-stage moderated mediation model through the Monte Carlo capability of Mplus (Muthén \& Muthén, 2012). By means of the Monte Carlo function of Mplus, data are generated from a population with hypothesized parameter values. A large number of samples (e.g., 100, 200, and 500) are drawn and the hypothesized model is estimated for each sample. Parameter estimates and standard errors are averaged over the samples (Muthén \& Muthén, 2012). I conservatively specified the parameter estimates ranging from 0.20 to 0.30 and 500 samples (or replications) were drawn to conduct the Monte Carlo analysis. As Muthén and Muthén (2012, p. 601) suggested, "the sample size is chosen to keep power close to 0.80. The value of 0.80 is used because it is a commonly accepted value for sufficient power." To reach a 
power closer to 0.80 or larger, I have to recruit at least 200 - 250 employee-supervisor dyads. The sample size in this study was 291 employee-supervisor dyads.

This study adopted a time-lagged design. The data was collected via survey instruments that were completed by employees and their supervisors in organizations. It is a multi-source and three-wave data collection to alleviate concerns about common method bias (Podsakoff, MacKenzie, Lee, \& Podsakoff, 2003). With regard to the time interval between waves, scholars have discussed optimal time lags in time-lagged or longitudinal studies (Collins, 2006; Dormann \& van de Ven, 2014; Mitchell \& James, 2001). Mitchell and James (2001) have advised researchers to consider optimal time lags within a broader question of "when events occur, when they change, and how quickly they change" (p. 533). However, as Dormann and Griffin (2015) noted, little research or guidance has been devoted to the question of how long the time interval should be in time-lagged or longitudinal studies. For example, some researchers have their recommendations, such as "not too short" or "not too long" (cf. Boker \& Nesselroade, 2002), but they did not provide specific guidance about time lags.

Mitchell and James (2001, p. 537) noted, normally "the lag between measurement is chosen because of convenience, not theory, since theory rarely specifies the exact length of the causal lag" and that "past research can be useful in helping the researcher make predictions and gather data at times that should be helpful."

In the voice behavior literature, researchers have used different time intervals when they studied supervisors' reactions to employee voice behavior. For example, most of the extant studies adopted a cross-sectional design (Burris et al., 2017; Burris, 2012; Grant \& Mayer, 2009) while a few studies used a time-lagged design with 6-8 weeks (Liang et al., 2012; Li et al., 2017), 3-months (Li et al., 2017), or 1-year (Howell et al., 2015) as time intervals. However, 
researchers did not provide rationales for their choice of time intervals except noting that a timelagged design and multiple data sources were used to minimize common source bias (Podsakoff et al., 2003). Drawing on the existing voice behavior research on supervisors' reactions to employee voice behavior (e.g., cross-sectional, 6-8 weeks) and following Mitchel and James' (2001) suggestion, I chose 1-month as the time interval between each wave in this study.

\section{Measures}

The complete list of survey instruments used in this study is included in Appendix A. Also, the complete list of original survey instruments, which were adapted for the purpose of this study, are included in Appendix B. In general, the survey instruments used in this study are identical to the original scales. However, small changes were made to the introductory questions of the Prosocial Motive Scale, Self-serving Motive Scale, and Perceived Instrumentality Scale. The introductory questions for these three measures were adjusted to the voice context. All measures were originally written in English. Two bilingual business researchers performed translation and back-translation procedures, respectively (Brislin, 1970). In particular, one business researcher conducted translation from English (the original language) to Chinese, and the other business researcher conducted back-translation from Chinese to English (the original language). The back-translation was compared to the original text as a quality check on the original translation.

Voice (Time 1). Employees reported their voice behavior using the 3-item voice scale widely used by voice researchers (Burris et al., 2008; Burris, 2012; Detert \& Burris, 2007). The 3-item scale was adapted by Detert and Burris (2007) from Van Dyne and LePine's (1998) measure of voice behavior. Van Dyne and LePine (1998) originally developed a 6-item scale to measure voice behavior. However, voice behavior researchers (Burris, 2012; Liu et al., 2015) 
had concerns about the 6-item measure because some items failed to emphasize voice behavior as suggestion-based and challenging. The 3-item scale is scored on a Likert-type scale ranging from 1 (almost never) to 5 (almost always). A sample item is "I give suggestions to my supervisor about how to make our unit or organization better, even if others disagree." Cronbach's alpha is .85 .

Political Skill (Time 1). Employees reported their political skills using the 18-item scale developed by Ferris et al. (2005). The 18-item scale is scored on a Likert-type scale ranging from 1 (strongly disagree) to 7 (strongly agree). Sample items are "I am able to communicate easily and effectively with others," "I have good intuition or savvy about how to present myself to others," and "When communicating with others, I try to be genuine in what I say and do." Cronbach's alpha is .95 .

Prosocial Motive Attribution (Time 1). Following the existing research on prosocial motive (e.g., Grant \& Mayer, 2009), I used the 4-item scale developed by Grant (2008) to measure people's prosocial motive. The original scale (Grant, 2008) opens with an introductory question: "Why are you motivated to do your work?" I adapted this introductory question to the voice context: "Why do you think this employee engages in voice behavior?" Supervisors rated these four items: (1) Because this employee cares about benefiting others through his/her voice behavior; (2) Because this employee wants to help others through his/her voice behavior; (3) Because this employee wants to have positive impact on others; and (4) Because it is important to this employee to do good for others through his/her voice behavior. The 4-item scale is scored on a Likert-type scale ranging from 1 (strongly disagree) to 7 (strongly agree). Cronbach's alpha is .91 . 
Self-serving Motive Attribution (Time 1). Following the existing research on self-serving motive (e.g., Grant \& Mayer, 2009; Halbesleben et al., 2010), I used the 10-item scale developed by Rioux and Penner (2001) to measure self-serving motive attribution. The original scale opens with an introductory question: "How important would each motive statement be in this employee's decision to engage in OCB at a job?" I adjusted the introductory question to the voice context: "Why do you think this employee engages in voice behavior?" Then, supervisors rated the 10 items. Sample items are: "Because this employee wants to impress me," "Because this employee wants to look better than others," and "Because this employee fears appearing irresponsible." The 10-item scale is scored on a Likert-type scale ranging from 1 (strongly disagree) to 7 (strongly agree). Cronbach's alpha is .91.

Perceived Instrumentality (Time 2). I used the 9-item scale developed by Baer (2012) to measure the perceived instrumentality of implementing the suggested change. Baer's (2012) 9item scale opens with an introductory question: "Here are some things that could happen to people if they tried to turn their ideas into a new product, process, or procedure that is actually brought to market or implemented. How likely is it that each of these things would happen if you tried to implement your ideas?" I adapted the introductory question to the voice context: "Here are some things that could happen to people if they tried to turn their employees' ideas into a new product, process, or procedure that is actually brought to market or implemented. How likely is it that each of these things would happen if you tried to implement the suggested changes brought up by this employee?" Except for the introductory question, the nine items remained unchanged from the original items developed by Baer (2012). Supervisors responded to the following items using a scale that ranges from 1 (not at all likely) to 7 (extremely likely). Sample items are: "I will enhance my reputation," "I will be given chances to learn new things," 
"I will encounter resistance or active opposition (reverse-scored)", and "I will get the feeling that I have accomplished something worthwhile". Cronbach's alpha is .87 .

Voice Endorsement (Time 2). Supervisors reported voice endorsement using the 5-item scale developed by Burris (2012). Sample items are "How likely is it that you will take this employee's comments to your supervisors," "This employee's comments are valuable," and "I will take this employee's comments to my supervisors." Supervisors responded to the 5 items using a scale that ranges from 1 (strongly disagree/very unlikely) to 5 (strongly agree/very likely). The reliability of the 5-item scale is 0.83 (Burris, 2012). Cronbach's alpha is .93 .

Voice Implementation (Time 3). Supervisors reported voice implementation using the 3item scale developed by Baer (2012). Following Baer (2012), the 3-item scale begins with an introductory question: "Please rate the frequency with which this employee's ideas ..." Then, supervisors responded to the following items using a scale that ranges from 1 (never) to 7 (always): ... have been approved for further development; ... have been transformed into usable products, processes, or procedures; and ... have been successfully brought to market or have been successfully implemented. Cronbach's alpha is .97.

Control Variables (CVs, Time 1). In their article on guidelines for the inclusion of control variables, Carlson and Wu (2012, p. 413) advocated to adopt "a conservative stance toward the inclusion of CVs [control variables] in the analysis of quasiexperimental and correlational designs guided by the principle 'When in doubt, leave them out'..' In this study, based on the prior literature on voice, I included two control variables - employee loyalty to the organization and relationship quality with the supervisor (i.e., LMX). I included them because these two variables may confound the relationship between employee voice and supervisor motive attribution, and the relationship between employee voice and supervisor voice 
endorsement. That is, it may be possible that employee loyalty and LMX with supervisors are reasons for both employee voice frequency (i.e. the independent variable in the study) and supervisors' motive attributions for employee voice behavior and supervisor voice endorsement (i.e., the dependent variables in the study), making these relationships spurious. First, Hirschman (1970) theorized loyalty as a major predictor of employee voice because loyal employees are motivated to help organizations with its continuous improvement. Scholars also showed that LMX predicts employee voice (Liu et al., 2013; Van Dyne et al., 2008). Second, employee loyalty and LMX can also affect supervisor motive attributions and endorsement of employee voice. For example, as Burris (2012, p. 856) argued, supervisors tend to generate positive expectations of loyal employees and these positive expectations lead supervisors to "believe that loyal employees are concerned with and behave in ways that positively impact the organization." LMX may also affect supervisor voice endorsement due to ingroup favoritism (Huang, Xu, Huang, \& Liu, 2018; Wilson, Sin, \& Conlon, 2010). Thus, given the potential confounding effects of loyalty and LMX, I controlled for them in all data analyses. Nonetheless, it is important to note that the significance patterns of the reported findings of hypothesis testing remained the same regardless of whether these variables were controlled or not. Employees reported their loyalty to the organization using a seven-item scale (Boroff \& Lewin, 1997). The Cronbach alpha was .92. Employees reported their relationship quality with their supervisor using the seven-item LMX scale (Liden et al., 1993). The Cronbach alpha was .90.

\section{Statistical Analysis}

Employees in my sample were nested within their supervisors who were, in turn, nested within organizations. The non-independence of data poses a threat to common regression analyses. This is because non-independence will affect the estimation of standard errors which is 
used to establish statistical significance (Hofmann, 1997). Therefore, I adopted hierarchical linear modeling analysis to appropriately account for the non-independence of the data structure (Bryk \& Raudenbush, 1992; Hofmann, 1997). Further, according to Bliese and Hanges (2004), ignoring non-independence when modeling only lower level variables will also reduce power.

To gauge the level of non-independence in this study, I calculated ICC (1) (Bliese, 2000; Bliese \& Hanges, 2004). ICC (1) indicates the amount of total variance explained by group membership. According to Bliese and colleagues (Bliese, 2000; Bliese \& Hanges, 2004), ICC (1) values ranging between .15 and .25 are typical in field settings and they represent moderate and moderately high ICC (1) values. As reported later in the Results section, the ICC (1) values for the dependent variables in this study ranged from .18 to .32, suggesting moderate to high ICC (1) values. The moderate to high ICC (1) values suggest that non-independence should be controlled in the data analyses, which otherwise could lead to biased standard errors and also reduce power (Bliese \& Hanges, 2004; Hofmann, 1997).

As for how to control for non-independence in hierarchical linear modeling, Bliese and Hanges (2004, p. 406) suggested that "one can incorporate a random error term associated with group membership if data are collected from individuals nested in groups. In so doing, one effectively partitions the total variance into a within-group and a between-group component and thereby effectively controls for non-independence" (also see Bryk \& Raudenbush, 1992; Hox, 2010; Snijders \& Bosker, 2012). Specifically, in hierarchical linear modeling analyses, "Y was regressed on X, and a random intercept term was estimated to account for non-independence" (Bliese \& Hanges, 2004, p. 410). Given the 3-level hierarchical linear modeling analyses in the current study, I specified two random intercept terms (at level 2 and level 3 respectively), plus a level 1 residual error term. In this way, I provided separate estimates of employee-level (level 1) 
residual variance, supervisor-level (level 2) variance in the dependent variables, and organization-level (level 3) variance in the dependent variables (Bliese \& Hanges, 2004). I reported these estimated variance components in Table 5 (in the random effects parts in Table 5).

The hierarchical linear modeling analyses were conducted using Stata 12 with the maximum likelihood estimation method. As Hox (2010, p. 40) noted, "Maximum likelihood (ML) is the most commonly used estimation method in multilevel modeling. An advantage of the maximum likelihood estimation method is that it is generally robust, and produces estimates that are asymptotically efficient and consistent." According to Hox (2010), the ML method is an estimation procedure that produces population parameter estimates which will maximize the probability of observing the actual data. The ML method uses an iterating procedure to generate parameter estimates (Hox, 2010). The default number of iterations in Stata is 20. All hierarchical linear analyses in this study converged within the default number of iterations.

Based on Hox's (2010) recommendation and the existing voice literature (e.g., Liang et al., 2012; Tangirala \& Ramanujam, 2008; Venkataramani \& Tangirala, 2010; Walumbwa \& Schaubroeck, 2009), I adopted grand mean centering in the hierarchical linear modeling analyses, which facilitate interpretation as it makes the "zero" value of predictor variables meaningful (Hox, 2010). In his book on multilevel modeling, Hox (2010, p. 61) stated that "The usual practice is that the overall or grand mean is subtracted from all values of a variable, which is called centering on the grand mean, or grand mean centering in short. If we apply grand mean centering, we solve the problem, because now the intercept in the regression equation is always interpretable as the expected value of the outcome variable, when all explanatory variables have their mean value." 
Prior to conducting hypothesis testing, I first established the discriminant validities of the constructs by conducting a set of confirmatory factor analyses. Fit indices were reported to determine how the measurement models fit the data. According to Hu and Bentler (1998), values of comparative fit index (CFI) and Tucker-Lewis index (TLI) that are greater than 0.95 represent a good model fit; values of the root mean square error of approximation (RMSEA) that are less than 0.08 indicate a good model fit. I reported the fit indices for the hypothesized model and conducted chi-square difference tests between the hypothesized model and alternative factor models in Table 4. 


\section{CHAPTER V. RESULTS}

Table 3 presents descriptive statistics and bivariate correlations of the studied variables. Prior to the hypothesis testing, I performed a set of confirmatory factor analyses (CFAs) to assess the discriminant validity of the studied measures (see Table 4). I compared seven alternative models. I found that Model 1 (i.e., the hypothesized 7-factor model) has a good fit: $\chi^{2}(254, \mathrm{~N}=291)=448.47$, comparative fit index $(\mathrm{CFI})=.97$, Tucker-Lewis index $(\mathrm{TLI})=.96$, root mean squared error of approximation $($ RMSEA $)=.05$. Further, as shown in Table 4, the hypothesized 7-factor model has a significantly better fit than all the alternative models.

To test the hypotheses, I conducted hierarchical linear modeling (HLM) analyses to account for the potential non-independence of observations since employees are nested within supervisors who are nested within organizations (Bliese, 2000). Indeed, the ICC (1) for voice endorsement at the supervisor level was .25 and was .18 at the organization level. Similarly, the ICC (1) for voice implementation at the supervisor level was .32 and was .20 at the organization level. As noted earlier, ICC (1) indicates the amount of total variance explained by group membership and gauges the level of non-independence (Hox, 2010). Therefore, I conducted 3-level hierarchical linear modeling analyses to account for nonindependence at both the supervisor and organization levels. To test the significance of the hypothesized moderated mediation effects, I adopted the bootstrapping approach recommended by Preacher, Rucker, and Hayes (2007). All analyses were conducted using Stata 12 .

Hypothesis 1 states that employees' voice behavior and political skills interactively affect supervisors' prosocial motive attribution, such that the relationship between employee voice behavior and supervisors' prosocial motive attribution will be positively stronger as employees' political skills increase. As shown in Table 5 (see Model 3), I found a significant 
interaction effect between employee voice and political skills on supervisor prosocial motive attribution $(\gamma=-0.16, p<.01)$. The interaction pattern was plotted in Figure 2. As shown, when employee political skills are higher, there is no relationship between voice behavior and supervisor prosocial motive attribution. In contrast, when political skills are lower, the more frequently employees engage in voice behavior, the more likely supervisors attribute employee voice behavior to a prosocial motive. Thus, Hypothesis 1 was not supported. Although the pattern was inconsistent with what I originally hypothesized, it revealed some interesting findings which are discussed in the next chapter.

Hypothesis 2 states that employees' voice behavior and political skills interactively affect supervisors' self-serving motive attribution, such that the relationship between employee voice behavior and supervisors' self-serving motive attribution will become positively stronger as employees' political skills decrease. As shown in Table 5 (Model 4), the interactive effect of employee voice and political skills on supervisor self-serving motive attribution is not significant $(\gamma=-0.04, p=0.47)$. Thus, Hypothesis 2 was not supported.

Hypothesis 3 states that supervisors' perceived instrumentality of suggested changes moderates the relationship between supervisor prosocial motive attribution and voice endorsement such that the positive effect of prosocial motive attribution on voice endorsement will be strengthened as supervisor perceived instrumentality increases. As shown in Table 5 (Model 6), I found a significant interaction effect between supervisor prosocial motive attribution and perceived instrumentality on supervisor voice endorsement $(\gamma=-0.06, p<.05)$. The interaction pattern was depicted in Figure 3. As shown, when supervisors perceive a higher level of instrumentality of implementing suggestions voiced by employees, there is no relationship between supervisor prosocial motive attribution and supervisor voice endorsement. In other words, when supervisors perceive employees' suggestions to be very instrumental, they will endorse them regardless of the degree of 
prosocial motive attribution they make. By contrast, when supervisors perceive a lower level of instrumentality, the relationship between supervisor prosocial motive attribution and voice endorsement is positive $(\gamma=0.11, p<.01)$. That is, when supervisors perceive lower instrumentality of employees' suggestions, they are more likely to endorse those suggestions perceived as more prosocially driven. Although a significant interaction effect was detected, the pattern was not consistent with what was originally hypothesized. Thus, Hypothesis 3 was not supported. Although the pattern was not consistent with what I originally hypothesized, it revealed some novel findings which are discussed in the next chapter.

Hypothesis 4 states that supervisors' perceived instrumentality of suggested changes will moderate the negative effect of self-serving motive attribution on voice endorsement such that the negative effect of supervisor self-serving motive attribution will be weakened as supervisor perceived instrumentality increases. As shown in Table 3 (Model 6), I found a significant interaction effect between supervisor self-serving motive attribution and perceived instrumentality on supervisor voice endorsement $(\gamma=0.08, p<.01)$. The interaction pattern was plotted in Figure 4. As shown, when supervisors perceive a higher level of instrumentality of implementing suggestions voiced by employees, there is no relationship between supervisor self-serving motive attribution and supervisor voice endorsement. In other words, when supervisors perceive employees' suggestions to be very instrumental, supervisor self-serving motive attribution for voice behavior does not impact whether they will endorse or decline employee voice. In contrast, when supervisors perceive a lower level of instrumentality, the relationship between supervisor self-serving motive attribution and voice endorsement is negative $(\gamma=-0.08, p<.05)$. In sum, as supervisors' perceived instrumentality increased, the negative effect of supervisor self-serving motive attribution for employee voice behavior on supervisor voice endorsement was weakened. Thus, Hypothesis 4 was supported. 
Hypothesis 5 states that supervisor voice endorsement is positively related to voice implementation. As shown in Table 5 (Model 7), there was a significant relationship between voice endorsement and voice implementation $(\gamma=1.16, p<.01)$. Thus, Hypothesis 5 was supported.

Hypothesis 6 states the serial mediation from employee voice behavior to voice implementation via supervisor prosocial motive attribution and voice endorsement is moderated by employee political skills and supervisor perceived instrumentality. Table 6 presents the results of bootstrapping analyses on the moderated mediation effects. As shown, only when both employee political skills and supervisor perceived instrumentality are low, there was a significant mediation effect of prosocial motive attribution in the relationship between employee voice and supervisor voice endorsement $(\gamma=0.036$, bias-corrected $95 \%$ confidence interval $=[0.014,0.067])$. Similarly, only when both employee political skills and supervisor perceived instrumentality are low, there was a significant serial mediation effect of prosocial motive attribution and supervisor voice endorsement in the relationship between employee voice behavior and supervisor voice implementation $(\gamma=0.042$, bias-corrected $95 \%$ confidence interval $=[0.021,0.091])$. Thus, these results supported Hypothesis 6 , which proposed a two-stage moderated mediation effect.

Hypothesis 7 states the serial mediation from employee voice behavior to voice implementation via supervisor self-serving motive attribution and supervisor voice endorsement is moderated by employee political skills and supervisor perceived instrumentality. However, because the first-stage moderating effect of political skills on the relationship between employee voice behavior and supervisor self-serving motive attribution (i.e., Hypothesis 2) was not significant, I only calculated the moderated mediation effects at the conditional values of supervisor perceived instrumentality. Table 7 presents the results of bootstrapping analyses on the moderated mediation effects. As shown, when perceived 
instrumentality is lower, there was a significant negative mediation effect of self-serving motive attribution in the relationship between employee voice behavior and supervisor voice endorsement $(\gamma=-0.018$, bias-corrected $95 \%$ confidence interval $=[-0.038,-0.068])$. When perceived instrumentality is higher, there was a significant positive mediation effect of selfserving motive attribution in the relationship between employee voice behavior and supervisor voice endorsement $(\gamma=0.012$, bias-corrected $95 \%$ confidence interval $=[0.001$, 0.037]). Similarly, when supervisors perceived instrumentality was lower, there was a significant negative serial mediation effect of self-serving motive attribution and supervisor voice endorsement in the relationship between employee voice behavior and voice implementation $(\gamma=-0.020$, bias-corrected 95\% confidence interval $=[-0.039,-0.008])$. When supervisors perceived instrumentality was higher, there was a significant positive serial mediation effect of self-serving motive attribution and supervisor voice endorsement in the relationship between employee voice behavior and voice implementation $(\gamma=0.014$, biascorrected $95 \%$ confidence interval $=[0.002,0.038])$. These results only supported a secondstage moderated mediation effect. Thus, Hypothesis 7 was not supported. Figure 5 exhibits the overall research model with path coefficients. 


\section{CHAPTER VI. DISCUSSION}

The purpose of this study is to unravel the mediating and moderating mechanisms that can explain when and why employee voice behavior leads to supervisor endorsement and implementation. Specifically, taking a socio-political perspective, I argued that supervisor motive attributions for employee voice behavior can explain the extent to which supervisors endorse and subsequently implement employee voice. Furthermore, I argued that the mediating effects of supervisor motive attributions in the relationship between employee voice behavior and supervisor voice endorsement are moderated by employee political skills in the first stage of the mediating path (i.e., from voice behavior to supervisor motive attributions) and by supervisor perceived instrumentality of implementing employees' suggestions in the second stage of the mediating path (i.e., from supervisor motive attributions to supervisor endorsement). Through a three-wave, multi-source field study, I found support for some of the hypothesized relationships. Although there were some unexpected findings which will be discussed in the following sections, the general picture that the findings depicted was that employee political skills, supervisor motive attributions, and supervisor perceived instrumentality indeed play roles in supervisor voice endorsement and implementation. In the following sections, I will first recap the key research findings, discuss their meaning, and provide possible explanations for unexpected but novel findings. After that, I will discuss the theoretical and practical implications of these study findings. Lastly, I will discuss the limitations of this study and possible future research directions.

\section{Summary of Key Findings}

First, I found that employee voice is positively related to both supervisor prosocial and self-serving motive attributions for employee voice. This finding is consistent with the 
theoretical claim in the voice literature that employee voice may be driven by dual motives: prosocial and self-serving motives (Klass et al., 2012; Morrison, 2014), at least from the supervisor's perspective.

Second, I found that supervisor prosocial motive attribution is positively associated with supervisor voice endorsement, whereas supervisor self-serving motive attribution has no significant effect on voice endorsement. The findings suggest that when deciding whether to endorse employee voice, supervisors seem to give weight to employee prosocial motive and give little weight to employee self-serving motive. In other words, when making a decision whether to endorse suggested changes, supervisors do not mind whether the voicers aim to promote their own interest, but do mind whether the voicers intend to benefit the collective interest.

Third, I found that employee political skills significantly moderate the relationship between employee voice and supervisor prosocial motive attribution. Despite this significant moderating effect of political skills in the relationship between employee voice and supervisor prosocial motive attribution, its exact patterns depart from what was predicted. Specifically, I originally argued that political skills should strengthen the positive effect of employee voice behavior on supervisor prosocial motive attribution. However, I found that as political skills increase, the effect of employee voice behavior on supervisor prosocial motive attribution changed from positive to null. While this is inconsistent with my original predictions, it is consistent with a study finding that Harris and colleagues (2007) reported. Harris and colleagues (2007) studied how political skills moderate the effects of influence tactics including selfpromotion and supplication on supervisor ratings of employee performance. Like this study, they expected that political skills should strengthen the positive effects of the two influence tactics (self-promotion and supplication) on supervisor ratings of employee performance, but they found 
political skills nullified the effects of these two influence tactics, which is similar to this study.

The findings of this study seem to suggest that for less politically skilled employees, they may need to spend more effort (e.g., contribute more new ideas or suggestions) in order to be perceived as prosocial. By contrast, for politically skilled employees, their frequency of voice behavior does not matter in supervisor prosocial motive attribution. Nonetheless, future research is needed to test the robustness of this reasoning of the unexpected positive relationship between employee voice behavior and supervisor prosocial motive attribution for less politically skilled employees. In addition, I found that employee political skills do not moderate the relationship between employee voice behavior and supervisor self-serving motive attribution, which is inconsistent with my original prediction. As the ICC (1) values indicated, there may be factors at the supervisor-level or organization-level that could explain the observed effect of political skills (Andrews, Kacmar, \& Harris, 2009). Future research is needed to test this possibility.

Fourth, I found that supervisor perceived instrumentality of implementing employee voice significantly moderates the effects of supervisor motive attributions on employee voice endorsement. The findings of this study revealed that supervisor perceived instrumentality is such a powerful force in affecting supervisor voice endorsement that it can nullify the effects of supervisor motive attributions on supervisor voice endorsement. Specifically, for the prosocial motive attribution path, I originally hypothesized that the positive effect of supervisor prosocial motive attribution on voice endorsement would be strengthened as supervisors perceive greater instrumentality. What I found is that when supervisors perceive greater instrumentality of implementing suggested changes, supervisor prosocial motive attribution plays no role in voice endorsement. However, when supervisors perceive lower instrumentality, supervisor prosocial motive attribution then comes into play in a positive manner. For the self-serving motive 
attribution path, the findings supported the hypothesis that the negative effect of supervisor selfserving motive attribution will be weakened as supervisor perceived instrumentality increases. In this study, I observed that the effect of supervisor self-serving motive attribution on voice endorsement changed from negative to null as supervisors perceived instrumentality increases. Taken together, the findings suggest that supervisor perceived greater instrumentality makes motive attributions (whether prosocial or self-serving) unimportant in affecting voice endorsement. That is, when supervisors perceive greater instrumentality, supervisors tend to endorse suggested changes voiced by employees regardless of employees' motives. In contrast, when supervisors perceive lower instrumentality, supervisors are more likely to endorse employee voice perceived as more prosocial and less self-serving. Implications of these findings are discussed in the following paragraphs.

\section{Theoretical Implications}

Implications for the voice literature. This study contributes to the voice literature in two primary ways. First, as reviewed earlier, the majority of the extant voice literature focused on studying antecedents of employee voice behavior (e.g., Liu et al., 2010). Only a few studies examined the outcomes of employee voice behavior (e.g., Howell et al., 2015). Among the studies examining the outcomes of voice behavior, even fewer studies examined supervisor voice endorsement and voice implementation (Burris, 2012; Howell et al., 2015; Lam et al., 2018). This study not only examined the relationship between employee voice behavior and supervisor voice endorsement/implementation but also investigated psychological mediating mechanisms and their boundary conditions that can explain the relationship between employee voice behavior and supervisor voice endorsement/implementation. Thus, this study significantly contributes to the voice literature by introducing the sociopolitical perspective to better understand why 
supervisors react differently to employee voice behavior. Future research may consider adopting the sociopolitical lens to examine the relationship between employee voice behavior and other potential outcomes such as employee career success as indicated by salary growth, number of promotions, and career satisfaction. In fact, in one study, scholars (Seibert, Kraimer, \& Crant, 2001) found that employee voice has a negative relationship with career success. I suggest that this study and its associated sociopolitical perspective may offer insights into the negative relationship between employee voice behavior and employee career progression. For example, future studies may examine the roles of supervisor motive attributions of employee voice behavior and supervisor perceived instrumentality of employee voice behavior in affecting the relationship between employee voice behavior and employee career success.

Second, despite voice being conceptualized as a prosocial behavior (Van Dyne \& LePine, 1998), little research has examined whether voice behavior will be perceived as prosocial in the eyes of beholders. It is important to study how beholders, such as supervisors, make motive attributions for employee voice behavior. This is because supervisors' motive attributions affect supervisors' emotional and behavioral reactions to employees (Halbesleben et al., 2010; Weiner, 1980), which have far-reaching effects on innovation processes (Janssen, 2003; Janssen et al., 2004), employees' future engagement in such behavior (Fast et al., 2014), and employees' commitment (McClean et al., 2013). The findings showed that supervisors tend to make both prosocial and self-serving motive attributions for employee voice behavior (see Table 5: Model 1 and 2). In other words, in the eyes of supervisors, employee voice is not a purely prosocial behavior. Also, past research has shown that supervisors are able to accurately detect their employees' OCB motives (Donia et al., 2016). Thus, the findings of this study, along with past research, indirectly lent support to Morrison's (2014) and Klaas et al.'s (2012) commentary 
about the potential dual motives of employee voice behavior. Future research may consider directly examining whether employee voice behavior is driven by employee prosocial and selfserving motives (i.e., employee self-reported motives) and if so, to what extent voice behavior is driven by both motives.

Implications for the motive attribution literature. In the motive attribution literature, it has been widely assumed that supervisors tend to react more favorably to employee discretionary behavior when they attribute this behavior to a prosocial motive and react more negatively when they perceive this behavior as self-serving (Halbesleben et al., 2010; Weiner, 1980; Whiting et al., 2012). This study identified supervisors' perceived instrumentality as a boundary condition which can neutralize the effects of supervisor motive attributions on their reactions towards employee voice behavior. The study findings illustrated that when supervisors perceive greater instrumentality of implementing employee suggestions, supervisors' motive attributions for employee voice behavior, regardless of whether the motive attribution is prosocial or selfserving, no longer play a role in affecting supervisor voice endorsement. In contrast, when supervisors perceive lower instrumentality, supervisor motive attributions matter in affecting supervisor voice endorsement. Specifically, supervisors are more likely to endorse voice behaviors perceived as more prosocial and less self-serving. Also, supervisors are more likely to endorse employees' suggestions with higher instrumentality, relative to suggestions with lower instrumentality. The study findings extended motive attribution theory and the extant motive attribution literature by revealing a boundary condition under which the effects of motive attributions on attitudinal and behavioral outcomes can vary.

In addition, this study helped confirm that prosocial and self-serving motive attributions are two distinct constructs instead of the two ends of one continuum. In prior research, there has 
been a controversy over whether prosocial and self-serving motives are two distinct constructs or two ends of one continuum (e.g., Grant \& Mayer, 2009). Recently, researchers have offered empirical evidence supporting the two motives (self-reported) as two independent constructs (Halbesleben et al., 2010; Rioux \& Penner, 2001). This study further supports that the two motives are distinct constructs even in the eyes of beholders (other-reported).

\section{Practical Implications}

This study focused on uncovering the mediating and moderating mechanisms that underlie the relationship between employee voice behavior and supervisor voice endorsement/implementation. An understanding of these mechanisms has significant practical implications. In the following paragraphs, I highlight the key findings and discuss their implications for employees and organizations.

First, I found that supervisor motive attributions for employee voice behavior, particularly the prosocial motive attribution, play an important role in explaining why supervisors will endorse and in turn implement employees' suggested changes. As informed by the study findings that supervisor prosocial motive attribution is positively associated with supervisor voice endorsement, for employees who intend to share ideas and suggestions with supervisors, they need to make their supervisors feel their voice behaviors are prosocially driven in order to get endorsed by supervisors. For example, employees can highlight to their supervisors how their ideas or solutions can benefit others and the organization. For organizations, they may also find it beneficial to enhance employee prosocial motivation. As the findings showed, supervisors are more likely to endorse prosocially motivated voice (see Model 5 in Table 5). Being perceived as prosocial, employees will be more likely to get their ideas endorsed and less likely to feel discouraged to offer new ideas to improve the organization. 
Given that researchers have observed that supervisors are able to detect employees' motives underlying their discretionary behaviors (Donia et al. 2016), it may be helpful for employees to promote their prosocial motivation. The extant literature has provided some recommendations to enhance employee prosocial motivation (e.g., Grant, 2007). In particular, Grant (2007) suggested that employee prosocial motivation can be enhanced by intervening on two relational job features: job impact on beneficiaries and opportunities to make contact with the beneficiaries. Organizations may consider creating these two relational job features in order to improve employee prosocial motivation.

Second, I found that supervisor perceived instrumentality of implementing employee voice plays a very critical role in affecting supervisor endorsement of employee voice. In particular, I found that supervisor perceived instrumentality of implementing employee voice can render supervisor motive attributions for employee voice behavior less important. Therefore, regardless of supervisors' motive attributions for voice, employees should consider enhancing instrumentality of their suggested ideas to their supervisors in order to get their suggested changes endorsed and implemented. For example, employees could highlight how their ideas can meet their supervisors' priorities and address their concerns (Ashford \& Detert, 2015). For organizations, they need to incentivize their supervisors to implement employee ideas to continuously improve work processes, products, and services. Otherwise, supervisors may not be motivated to expend time, energy, and resources to change the status quo and implement ideas offered by employees. That could be a potential loss to organizations because employees are in the frontlines to observe problems and opportunities, and hence their ideas are an important source of the continuous improvement and competitive advantages of organizations (Burris \& Detert, 2007; Morrison \& Milliken, 2000). 
Third, I found that supervisor voice endorsement is a precursor to voice implementation in organizations. Therefore, for employees who seek to get their ideas implemented in their organizations, it is important for employees to obtain endorsement from their direct supervisors. This study finding supported the critical linking pin function of supervisors (Burris \& Trevino, 2010). Hence, organizations should be careful in appointing members to supervising positions because supervisors can significantly affect the flow of employee ideas into the actual implementation in the organization as shown in this study. In this regards, organizations focusing on continuous improvement may seek to appoint or otherwise train supervisors to be more open to and more appreciative of employee voice behavior (Burris \& Detert, 2007).

\section{Limitations and Directions for Future Research}

This study has limitations that future research needs to address. First, all the studied variables in this study are perceptual in nature as they are either reported by employees or their supervisors. Therefore, common method bias may be a concern for this study. However, common method bias may not be a serious issue in this study for two reasons: (1) following Podsakoff and colleagues' (2003) recommendations, I used a multi-source and time-lagged design to reduce the concerns over common method bias, and (2) researchers have shown that significant interaction effects could not be an artifact of common method bias (Siemsen, Roth, \& Oliveira, 2010). Therefore, the significant interaction effects found in this study cannot be attributed to common method bias. Nonetheless, future research should consider using objective measures for some of the variables such as voice implementation. For example, if organizations have systems thoroughly recording how many solutions offered by employees have been put into practice, it will be truly helpful to use such a more objective measure of voice implementation. 
Second, although the adoption of a one-month time lag design is consistent with recent studies in the voice literature (Howell et al., 2015; Li et al., 2017; Liang et al., 2012), future studies may want to use a longer time lag between surveys than the one-month interval. Indeed, for some of the ideas employees suggested, it may take a longer time period for supervisors to realize the potential value of these ideas and to further mobilize resources to implement them. Nonetheless, in the two available studies on implementation of employee ideas, Baer (2012) used a one-time cross-sectional design, whereas Lu, Bartol, Venkataramani, Zheng, and Liu (2019) adopted a one-month time lag as this study did. Future studies may consider extending those studies and this study to conduct longitudinal tracking of the implementation of employee voiced ideas, which may allow researchers to map the typical time lag from idea voicing to idea implementation and thus may offer guiding information for future research on voice implementation.

Third, several theorists have called for attention to the role of contexts (from national cultures to occupational and task contexts) in management theorizing, and in particular to examining how these contextual factors may affect research findings (Jackson \& Schuler, 1995; Johns, 2017, 2018; Porter \& Schneider, 2014). Future research therefore may explore various contextual features of the study sample that may affect the research findings reported in this study. A first contextual factor to consider for future research is the cultural context where the study is embedded. This study was conducted in China, and hence the generalizability of the study findings to countries with different cultures remains an open question. Future crosscultural comparison studies are needed. According to Hofstede's (2001) global comparative data, China scores at the high end of the power distance continuum. Power distance refers to the extent to which individuals in a society expect and accept that power is distributed unequally (Hofstede, 
2001). Given voice is voluntary and challenging in nature, employees may be generally more reluctant to speak up or to suggest new ideas in Chinese organizations. As a result, the level of employee voice frequency might be lower compared with the level of employee voice frequency in countries with low power distance, which future cross-cultural research needs to explore. In addition, another consequence of high power distance culture might be that employees in high power-distance culture may engage in more frequent self-censoring of ideas and only share ideas if they truly believe they have good ideas that deserve supervisors' attention in order to avoid negative repercussion or losing face (Detert \& Edmondson, 2011; Williams, 2002). Selfcensoring means that employees withhold ideas that are "infeasible, ineffective or strange" (Williams, 2002, p. 496). This may also help partly explain why employees lacking political skills receive higher supervisor prosocial motive attribution when they share more improvementoriented ideas than when they offer few improvement-oriented ideas. That is, in a high powerdistance culture such as in China, these employees who lack political skills may be especially cautious in speaking up. As such, they may only offer ideas when they think their ideas really deserve their supervisors' attention. Consequently, supervisors will likely give them higher ratings of prosocial motive attribution when they speak up. Of course, when they seldom offer improvement-oriented ideas voluntarily, their supervisors are unlikely to make a prosocial motive attribution due to their lack of voice behavior and voluntary involvement in improving the organization. After all, in order to be perceived as prosocial, employees need to demonstrate active, voluntary efforts to sharing ideas and suggestions that could help supervisors or organizations.

A second contextual factor that may affect the findings is the occupational and task contexts of employees and their supervisors. The sample in this study consists of frontline 
employees and their immediate supervisors who are operating in various task domains from multiple organizations. Like most of the studies in the management field (for review, see Johns, 2018), my theorizing and sampling was not tailored to specific occupations/task domains (e.g., clerical tasks, R\&D, or sales etc.). Since theorists (Jackson \& Schuler, 1995; Johns, 2017, 2018; Porter \& Schneider, 2014) have noted the need to take study contexts into account when theorizing and hypothesis testing, future research may extend my study to collect data from specific occupations (e.g., R\&D versus routine, clerical tasks). As such, future research can directly incorporate the contextual task features into theorizing and empirically examine whether different occupations or task domains will affect the supervisor attribution processes for employee voice behavior. Such research direction is important as it will enable scholars to offer more contextualized recommendations for organizations and their employees (Jackson \& Schuler, 1995; Johns, 2018).

A third contextual factor that future research should consider is the dyadic relational context of employees and their supervisors. The relational demography literature (Tsui \& O’Reilly III, 1989), for example, has looked at the effects of similarity and dissimilarity in demographic variables in a supervisor-subordinate dyad on their attitudes and social interaction patterns. In their original study on relational demography, Tsui and O'Really III (1989) found that gender similarity is the only relational demography factor that has consistent and significant effects on all their studied outcome variables. But later studies found inconsistent effects of relational demography including gender similarity/dissimilarity (for review, see Riordan, 2000).

Given that I have the gender information of both supervisors and employees in the dataset, I have conducted additional analyses to examine the possible effects of dyadic gender similarity on the studied mediators and dependent variables. Similar to the mixed findings 
reported in the existing literature (Riordan, 2000), I did not find significant effects of dyadic gender similarity in my study. Specifically, I found that the effects of dyadic gender similarity on supervisor prosocial motive attribution was $\gamma=-0.11, p=.11$; on supervisor self-serving motive attribution was $\gamma=-0.02, p=.90$; on supervisor voice endorsement was $\gamma=-0.04, p=.64$; and on supervisor implementation of voice was $\gamma=-0.25, p=.10$. Further, the results of this study remained the same after incorporating dyadic gender similarity. The nonsignificant effects of dyadic gender similarity are also consistent with a few recent studies on gender similarity (Tepper, Moss, \& Duffy, 2011; Zhang, Wang, \& Shi, 2012). In explaining the nonsignificant effects of gender similarity, these scholars suggested that the effects of dyadic gender similarity may play a prominent role in newly formed teams or newly formed supervisor-subordinate dyads where they haven't developed a good understanding of each other. Future research may consider directly examining how relational demography affects voice dynamics in newly formed supervisor-subordinate dyads. For example, scholars may track fresh graduates and examine how their gender similarity/dissimilarity with their supervisor affects their voice behavior as well as their supervisor's reaction to their voice. 


\section{REFERENCES}

Aiken, L. S., West, S. G., \& Reno, R. R. (1991). Multiple regression: Testing and interpreting interactions. Newbury Park, CA: Sage.

Ajzen, I. (1991). The theory of planned behavior. Organizational Behavior and Human Decision Processes, 50(2), 179-211.

Ajzen, I. (2002). Perceived behavioral control, self-efficacy, locus of control, and the theory of planned behavior 1. Journal of Applied Social Psychology, 32(4), 665-683.

Andrews, M. C., Kacmar, K. M., \& Harris, K. J. (2009). Got political skill? The impact of justice on the importance of political skill for job performance. Journal of Applied Psychology, 94(6), 1427.

Ashford, S. J. (1986). Feedback-seeking in individual adaptation: A resource perspective. Academy of Management Journal, 29(3), 465-487.

Ashford, S. J., \& Detert, J. (2015). Get the boss to buy in learn to sell your ideas up the chain of command. Harvard Business Review, 93(1-2), 72-79.

Allen, T. D., \& Rush, M. C. (1998). The effects of organizational citizenship behavior on performance judgments: a field study and a laboratory experiment. Journal of Applied Psychology, 83(2), 247.

Aryee, S., Walumbwa, F. O., Mondejar, R., \& Chu, C. W. (2017). Core self-evaluations and employee voice behavior: Test of a dual-motivational pathway. Journal of Management, 43(3), 946-966.

Ashford, S. J. (1986). Feedback-seeking in individual adaptation: A resource perspective. Academy of Management Journal, 29(3), 465-487. 
Ashford, S. J., \& Black, J. S. (1996). Proactivity during organizational entry: The role of desire for control. Journal of Applied Psychology, 81(2), 199-214.

Ashford, S. J., Blatt, R., \& Walle, D. V. (2003). Reflections on the looking glass: A review of research on feedback-seeking behavior in organizations. Journal of Management, 29(6), 773-799.

Baer, M. (2012). Putting creativity to work: The implementation of creative ideas in organizations. Academy of Management Journal, 55(5), 1102-1119.

Bateman, T. S., \& Crant, J. M. (1993). The proactive component of organizational behavior: A measure and correlates. Journal of Organizational Behavior, 14(2), 103-118.

Bateman, T. S., \& Organ, D. W. (1983). Job satisfaction and the good soldier: The relationship between affect and employee "citizenship". Academy of Management Journal, 26(4), 587-595.

Bauer, D. J., \& Curran, P. J. (2005). Probing interactions in fixed and multilevel regression: Inferential and graphical techniques. Multivariate Behavioral Research, 40(3), 373-400.

Bauer, D. J., Preacher, K. J., \& Gil, K. M. (2006). Conceptualizing and testing random indirect effects and moderated mediation in multilevel models: New procedures and recommendations. Psychological Methods, 11(2), 142-163.

Baumeister, R. F. (1982). A self-presentational view of social phenomena. Psychological Bulletin, 91(1), 3-26.

Bernerth, J. B., \& Aguinis, H. (2016). A critical review and best practice recommendations for control variable usage. Personnel Psychology, 69(1), 229-283.

Bindl, U. K., \& Parker, S. K. (2010). Proactive work behavior: Forward-thinking and changeoriented action in organizations. In S. Zedeck (Ed.), APA handbook of industrial and 
organizational psychology (Vol. 2, pp. 567-598). Washington, DC: American Psychological Association.

Blass, F. R., \& Ferris, G. R. (2007). Leader reputation: The role of mentoring, political skill, contextual learning, and adaptation. Human Resource Management, 46(1), 5-19.

Bliese, P. D., \& Hanges, P. J. (2004). Being both too liberal and too conservative: The perils of treating grouped data as though they were independent. Organizational Research Methods, 7(4), 400-417.

Blickle, G., Schneider, P. B., Liu, Y., \& Ferris, G. R. (2011). A predictive investigation of reputation as mediator of the political skill/career success relationship. Journal of Applied Social Psychology, 41(12), 3026-3048.

Bolino, M. C. (1999). Citizenship and impression management: Good soldiers or good actors? Academy of Management Review, 24(1), 82-98.

Bolino, M. C., \& Grant, A. M. (2016). The bright side of being prosocial at work, and the dark side, too: A review and agenda for research on other-oriented motives, behavior, and impact in organizations. Academy of Management Annals, 10(1), 599-670.

Bolino, M. C., Hsiung, H. H., Harvey, J., \& LePine, J. A. (2015). “Well, I’m tired of tryin’!” Organizational citizenship behavior and citizenship fatigue. Journal of Applied Psychology, 100(1), 56-74.

Bolino, M. C., \& Klotz, A. C. (2015). The paradox of the unethical organizational citizen: The link between organizational citizenship behavior and unethical behavior at work. Current Opinion in Psychology, 6, 45-49. 
Boker, S. M., \& Nesselroade, J. R. (2002). A method for modeling the intrinsic dynamics of intraindividual variability: Recovering the parameters of simulated oscillators in multiwave panel data. Multivariate Behavioral Research, 37(1), 127-160.

Borman, W. C., \& Motowidlo, S. J. (1997). Task performance and contextual performance: The meaning for personnel selection research. Human Performance, 10(2), 99-109.

Boroff, K. E., \& Lewin, D. (1997). Loyalty, voice, and intent to exit a union firm: A conceptual and empirical analysis. ILR Review, 51(1), 50-63.

Botero, I. C., \& Van Dyne, L. (2009). Employee voice behavior interactive effects of LMX and power distance in the United States and Colombia. Management Communication Quarterly, 23(1), 84-104.

Bowler, W. M., Halbesleben, J. R., \& Paul, J. R. (2010). If you're close with the leader, you must be a brownnose: The role of leader-member relationships in follower, leader, and coworker attributions of organizational citizenship behavior motives. Human Resource Management Review, 20(4), 309-316.

Brislin, R. W. (1980). Translation and content analysis of oral and written material. In H. C. Triandis \& J. W. Berry (Eds.), Handbook of cross-cultural psychology (Vol. 2, pp. 349444). Boston, MA: Allyn \& Bacon.

Brockner, J., Heuer, L., Siegel, P. A., Wiesenfeld, B., Martin, C., Grover, S., . . Bjorgvinsson, S. (1998). The moderating effect of self-esteem in reaction to voice: Converging evidence from five studies. Journal of Personality and Social Psychology, 75(2), 394.

Bryk, A. S., \& Raudenbush, S. W. (1992). Hierarchical linear models: Applications and data analysis methods. Newbury Park, CA: Sage. 
Burris, E. R. (2012). The risks and rewards of speaking up: Managerial responses to employee voice. Academy of Management Journal, 55(4), 851-875.

Burris, E. R., Detert, J. R., \& Chiaburu, D. S. (2008). Quitting before leaving: the mediating effects of psychological attachment and detachment on voice. Journal of Applied Psychology, 93(4), 912-922.

Burris, E. R., Detert, J. R., \& Romney, A. C. (2013). Speaking up vs. being heard: The disagreement around and outcomes of employee voice. Organization Science, 24(1), 2238.

Burris, E. R., Rockmann, K. W., \& Kimmons, Y. S. (2017). The Value of Voice to Managers: Employee Identification and the Content of Voice. Academy of Management Journal, 60(6), 2099-2125.

Campbell, D. J. (2000). The proactive employee: Managing workplace initiative. Academy of Management Executive, 14(3), 52-66.

Carlson, K. D., \& Wu, J. (2012). The illusion of statistical control: Control variable practice in management research. Organizational Research Methods, 15(3), 413-435.

Chang, C. H., Rosen, C. C., \& Levy, P. E. (2009). The relationship between perceptions of organizational politics and employee attitudes, strain, and behavior: A meta-analytic examination. Academy of Management Journal, 52(4), 779-801.

Chen, G., Smith, T. A., Kirkman, B. L., Zhang, P., Lemoine, G. J., \& Farh, J. L. (2019). Multiple team membership and empowerment spillover effects: Can empowerment processes cross team boundaries? Journal of Applied Psychology, 104(3), 321-340.

Chen, Z., Zhu, J., \& Zhou, M. (2015). How does a servant leader fuel the service fire? A multilevel model of servant leadership, individual self-identity, group competition 
climate, and customer service performance. Journal of Applied Psychology, 100(2), 511521.

Ching, C., Holsapple, C. W., \& Whinston, A. B. (1992). Reputation, learning, and coordination in distributed decision-making contexts. Organization Science, 3(2), 275-297.

Choi, J. N. (2007). Change-oriented organizational citizenship behavior: Effects of work environment characteristics and intervening psychological processes. Journal of Organizational Behavior, 28(4), 467-484.

Cohen, J. and Cohen, P.(1983) Applied multiple regression/correlation analysis for the behavioral science (2nd ed). Hillsdale, NJL Lawrence Erlbaum Associates.

Collins, L. M. (2006). Analysis of longitudinal data: The integration of theoretical model, temporal design, and statistical model. Annual Review of Psycholology, 57, 505-528.

Crant, J. M. (2000). Proactive behavior in organizations. Journal of Management, 26(3), 435462.

Cullen, K. L., Gerbasi, A., \& Chrobot-Mason, D. (2018). Thriving in central network positions: The role of political skill. Journal of Management, 44(2), 682-706.

Den Hartog, D. N., \& Belschak, F. D. (2012). When does transformational leadership enhance employee proactive behavior? The role of autonomy and role breadth selfefficacy. Journal of Applied Psychology, 97(1), 194-202.

DeNisi, A. S., Cafferty, T. P., \& Meglino, B. M. (1984). A cognitive view of the performance appraisal process: A model and research propositions. Organizational Behavior and Human Performance, 33(3), 360-396.

Detert, J. R., \& Burris, E. R. (2007). Leadership behavior and employee voice: Is the door really open? Academy of Management Journal, 50(4), 869-884. 
Detert, J. R., Burris, E. R., Harrison, D. A., \& Martin, S. R. (2013). Voice flows to and around leaders: Understanding when units are helped or hurt by employee voice. Administrative Science Quarterly, 58(4), 624-668.

Detert, J. R., \& Edmondson, A. C. (2011). Implicit voice theories: Taken-for-granted rules of self-censorship at work. Academy of Management Journal, 54(3), 461-488.

Detert, J. R., \& Treviño, L. K. (2010). Speaking up to higher-ups: How supervisors and skiplevel leaders influence employee voice. Organization Science, 21(1), 249-270.

Donia, M. B., Johns, G., \& Raja, U. (2016). Good soldier or good actor? Supervisor accuracy in distinguishing between selfless and self-serving OCB motives. Journal of Business and Psychology, 31(1), 23-32.

Dormann, C., \& Griffin, M. A. (2015). Optimal time lags in panel studies. Psychological Methods, 20(4), 489-505.

Dutton, J. E., Ashford, S. J., O’neill, R. M., Hayes, E., \& Wierba, E. E. (1997). Reading the wind: How middle managers assess the context for selling issues to top managers. Strategic Management Journal, 18(5), 407-423.

Eccles, J. S., \& Wigfield, A. (2002). Motivational beliefs, values, and goals. Annual Review of Psychology, 53(1), 109-132.

Edmondson, A. (1999). Psychological safety and learning behavior in work teams. Administrative Science Quarterly, 44(2), 350-383.

Edmondson, A. C., \& Lei, Z. (2014). Psychological safety: The history, renaissance, and future of an interpersonal construct. Annual Review of Organizational Psychology and Organizational Behavior, 1(1), 23-43. 
Edwards, J. R., \& Lambert, L. S. (2007). Methods for integrating moderation and mediation: A general analytical framework using moderated path analysis. Psychological Methods, 12(1), 1-22.

Ensley, M. D., Hmieleski, K. M., \& Pearce, C. L. (2006). The importance of vertical and shared leadership within new venture top management teams: Implications for the performance of startups. The Leadership Quarterly, 17(3), 217-231.

Erdogan, B., \& Bauer, T. N. (2005). Enhancing career benefits of employee proactive personality: The role of fit with jobs and organizations. Personnel Psychology, 58(4), 859-891.

Farh, C. I., \& Chen, G. (2018). Leadership and member voice in action teams: Test of a dynamic phase model. Journal of Applied Psychology, 103(1), 97-110.

Farrell, D. (1983). Exit, voice, loyalty, and neglect as responses to job dissatisfaction: A multidimensional scaling study. Academy of Management Journal, 26(4), 596-607.

Fast, N. J., Burris, E. R., \& Bartel, C. A. (2014). Managing to stay in the dark: Managerial selfefficacy, ego defensiveness, and the aversion to employee voice. Academy of Management Journal, 57(4), 1013-1034.

Ferris, G. R., Bhawuk, D. P. S., Fedor, D. B., \& Judge, T. A. 1995. Organizational politics and citizenship: Attributions of intentionality and construct definition. In M. J. Martinko (Ed.), Advances in attribution theory: An organizational perspective: 231-252. Delray Beach, FL: St. Lucie Press.

Ferris, G. R., \& Judge, T. A. (1991). Personnel/human resources management: A political influence perspective. Journal of Management, 17(2), 447-488. 
Ferris, G. R., Blass, R., Douglas, C., Kolodinsky, R. W., \& Treadway, D. C. 2003. Personal reputation in organizations. In J. Greenberg (Ed.), Organizational behavior: The state of the science (2nd ed.): 211-246. Mahwah, NJ: Lawrence Erlbaum.

Ferris, G. R., Treadway, D. C., Kolodinsky, R. W., Hochwarter, W. A., Kacmar, C. J., Douglas, C., \& Frink, D. D. (2005). Development and validation of the political skill inventory. Journal of Management, 31(1), 126-152.

Ferris, G. R., Treadway, D. C., Perrewé, P. L., Brouer, R. L., Douglas, C., \& Lux, S. (2007). Political skill in organizations. Journal of Management, 33(3), 290-320.

Flynn, F. J., Reagans, R. E., Amanatullah, E. T., \& Ames, D. R. (2006). Helping one's way to the top: Self-monitors achieve status by helping others and knowing who helps whom. Journal of Personality and Social Psychology, 91(6), 1123-1137.

Frazier, M. L., \& Bowler, W. M. (2015). Voice climate, supervisor undermining, and work outcomes: A group-level examination. Journal of Management, 41(3), 841-863.

Frese, M. (2008). The word is out: We need an active performance concept for modern workplaces. Industrial and Organizational Psychology: Perspectives on Science and Practice, 1(1), 67- 69.

Frese, M., \& Fay, D. (2001). Personal initiative: An active performance concept for work in the 21st century. In B. M. Staw \& R. L. Sutton (Eds.), Reserach in organizational behavior (Vol. 23, pp. 133-187). Stamford, CT: JAI Press.

Frese, M., Garst, H., \& Fay, D. (2007). Making things happen: Reciprocal relationships between work characteristics and personal initiative in a four-wave longitudinal structural equation model. Journal of Applied Psychology, 92(4), 1084-1102. 
Fuller, B., \& Marler, L. E. (2009). Change driven by nature: A meta-analytic review of the proactive personality literature. Journal of Vocational Behavior, 75(3), 329-345.

Fuller, J. B., Marler, L. E., \& Hester, K. (2006). Promoting felt responsibility for constructive change and proactive behavior: Exploring aspects of an elaborated model of work design. Journal of Organizational Behavior, 27(8), 1089-1120.

Gangestad, S. W., \& Snyder, M. (2000). Self-monitoring: Appraisal and reappraisal. Psychological Bulletin, 126(4), 530-555.

Gong, Y., Kim, T. Y., Lee, D. R., \& Zhu, J. (2013). A multilevel model of team goal orientation, information exchange, and creativity. Academy of Management Journal, 56(3), 827-851.

Grant, A. M. (2007). Relational job design and the motivation to make a prosocial difference. Academy of Management Review, 32(2), 393-417.

Grant, A. M., \& Ashford, S. J. (2008). The dynamics of proactivity at work. Research in Organizational Behavior, 28, 3-34.

Grant, A. M., \& Mayer, D. M. (2009). Good soldiers and good actors: Prosocial and impression management motives as interactive predictors of affiliative citizenship behaviors. Journal of Applied Psychology, 94(4), 900-912.

Grant, A. M., Parker, S., \& Collins, C. (2009). Getting credit for proactive behavior: Supervisor reactions depend on what you value and how you feel. Personnel Psychology, 62(1), 3155.

Gruman, J. A., Saks, A. M., \& Zweig, D. I. (2006). Organizational socialization tactics and newcomer proactive behaviors: An integrative study. Journal of Vocational Behavior, 69(1), 90-104. 
Gorden, W. I. (1988). Range of employee voice. Employee Responsibilities and Rights Journal, 1(4), 283-299.

Halbesleben, J. R., Bowler, W., Bolino, M. C., \& Turnley, W. H. (2010). Organizational concern, prosocial values, or impression management? How supervisors attribute motives to organizational citizenship behavior. Journal of Applied Social Psychology, 40(6), 1450-1489.

Harris, K. J., Kacmar, K. M., Zivnuska, S., \& Shaw, J. D. (2007). The impact of political skill on impression management effectiveness. Journal of Applied Psychology, 92(1), 278-285.

Haworth, C. L., \& Levy, P. E. (2001). The importance of instrumentality beliefs in the prediction of organizational citizenship behaviors. Journal of Vocational Behavior, 59(1), 64-75.

Hirokawa, R. Y., \& Miyahara, A. (1986). A comparison of influence strategies utilized by managers in American and Japanese organizations. Communication Quarterly, 34(3), 250-265.

Hirschman, A. O. (1970). Exit, voice, and loyalty: Responses to decline in firms, organizations, and states. Cambridge, MA: Harvard University Press.

Hofmann, D. A. (1997). An overview of the logic and rationale of hierarchical linear models. Journal of Management, 23(6), 723-744.

Hofmann, D. A., \& Gavin, M. B. (1998). Centering decisions in hierarchical linear models: Implications for research in organizations. Journal of Management, 24(5), 623-641.

Hofstede, G. (2001). Culture's consequences: Comparing values, behaviors, institutions and organizations across nations. Sage publications. 
Hogan, R., Jones, W.H., \& Cheek, J.M. (1985). Socioanalytic theory: An alternative to armadillo psychology. In B.R. Schlenker (Ed.), The self and social life (pp. 175-198). New York: McGraw Hill.

Hogan, R., \& Shelton, D. (1998). A socioanalytic perspective on job performance. Human Performance, 11(2/3), 129-144.

Hornung, S., \& Rousseau, D. M. (2007). Active on the job-proactive in change: How autonomy at work contributes to employee support for organizational change. Journal of Applied Behavioral Science, 43(4), 401-426.

Howell, T. M., Harrison, D. A., Burris, E. R., \& Detert, J. R. (2015). Who gets credit for input? Demographic and structural status cues in voice recognition. Journal of Applied Psychology, 100(6), 1765-1784.

Hox, J. J. (2010). Multilevel analysis: Techniques and applications (2nd ed.). New York, NY, US: Routledge/Taylor \& Francis.

Hsiung, H. H., \& Tsai, W. C. (2017). The joint moderating effects of activated negative moods and group voice climate on the relationship between power distance orientation and employee voice behavior. Applied Psychology, 66(3), 487-514.

Hu, L. T., \& Bentler, P. M. (1998). Fit indices in covariance structure modeling: Sensitivity to underparameterized model misspecification. Psychological Methods, 3(4), 424.

Huang, X., Xu, E., Huang, L., \& Liu, W. (2018). Nonlinear consequences of promotive and prohibitive voice for managers' responses: The roles of voice frequency and LMX. Journal of Applied Psychology, 103(10), 1101-1120. 
Hui, C., Lam, S. S., \& Law, K. K. (2000). Instrumental values of organizational citizenship behavior for promotion: A field quasi-experiment. Journal of Applied Psychology, 85(5), 822-828.

Hyatt, D. E., \& Ruddy, T. M. (1997). An examination of the relationship between work group characteristics and performance: Once more into the breech. Personnel Psychology, 50(3), 553-585.

Jackson, S. E., \& Schuler, R. S. (1995). Understanding human resource management in the context of organizations and their environments. Annual Review of Psychology, 46(1), 237-264.

Janssen, O. (2003). Innovative behaviour and job involvement at the price of conflict and less satisfactory relations with co-workers. Journal of Organizational and Occupational Psychology, 76, 347-364.

Janssen, O. (2005). The joint impact of perceived influence and supervisor supportiveness on employee innovative behaviour. Journal of Occupational and Organizational Psychology, 78(4), 573-579.

Janssen, O., Van de Vliert, E., \& West, M. (2004). The bright and dark sides of individual and group innovation: A special issue introduction. Journal of Organizational Behavior, $25(2), 129-145$.

Jawahar, I. M., Meurs, J. A., Ferris, G. R., \& Hochwarter, W. A. (2008). Self-efficacy and political skill as comparative predictors of task and contextual performance: A two-study constructive replication. Human Performance, 21(2), 138-157.

Jiang, J., Gao, A., \& Yang, B. (2018). Employees' Critical Thinking, Leaders’ Inspirational Motivation, and Voice Behavior. Journal of Personnel Psychology. 17(1), 33-41. 
Johns, G. (2018). Advances in the treatment of context in organizational research. Annual Review of Organizational Psychology and Organizational Behavior, 5, 21-46.

Johns, G. (2017). Reflections on the 2016 decade award: incorporating context in organizational research. Academy of Management Review, 42(4), 577-595.

Johnson, D. E., Erez, A., Kiker, D. S., \& Motowidlo, S. J. (2002). Liking and attributions of motives as mediators of the relationships between individuals' reputations, helpful behaviors and raters' reward decisions. Journal of Applied Psychology, 87(4), 808-815.

Kacmar, K. M., Witt, L. A., Zivnuska, S., \& Gully, S. M. (2003). The interactive effect of leadermember exchange and communication frequency on performance ratings. Journal of Applied Psychology, 88(4), 764-772.

Kakkar, H., Tangirala, S., Srivastava, N. K., \& Kamdar, D. (2016). The dispositional antecedents of promotive and prohibitive voice. Journal of Applied Psychology, 101(9), 1342-1351.

Katz, D. (1964). The motivational basis of organizational behavior. Systems Research and Behavioral Science, 9(2), 131-146.

Klaas, B. S., Olson-Buchanan, J. B., \& Ward, A. K. (2012). The determinants of alternative forms of workplace voice: An integrative perspective. Journal of Management, 38(1), 314-345.

Klotz, A. C., \& Bolino, M. C. (2013). Citizenship and counterproductive work behavior: A moral licensing view. Academy of Management Review, 38(2), 292-306.

Kolodinsky, R. W., Treadway, D. C., \& Ferris, G. R. (2007). Political skill and influence effectiveness: Testing portions of an expanded Ferris and Judge (1991) model. Human Relations, 60(12), 1747-1777. 
Kong, F., Huang, Y., Liu, P., \& Zhao, X. (2017). Why voice behavior? An integrative model of the need for affiliation, the quality of leader-member exchange, and group cohesion in predicting voice behavior. Group \& Organization Management, 42(6), 792-818.

Kirkman, B. L., \& Rosen, B. (1999). Beyond self-management: Antecedents and consequences of team empowerment. Academy of Management Journal, 42(1), 58-74.

Lam, C. F., Lee, C., \& Sui, Y. (2018). Say it as it is: Consequences of voice directness, voice politeness, and voicer credibility on voice endorsement. Journal of Applied Psychology, $104(5), 642-658$.

LePine, J. A., \& Van Dyne, L. (1998). Predicting voice behavior in work groups. Journal of Applied Psychology, 83(6), 853-868.

LePine, J. A., \& Van Dyne, L. (2001). Voice and cooperative behavior as contrasting forms of contextual performance: Evidence of differential relationships with big five personality characteristics and cognitive ability. Journal of Applied Psychology, 86(2), 326-336.

LePine, M. A., Zhang, Y., Crawford, E. R., \& Rich, B. L. (2016). Turning their pain to gain: Charismatic leader influence on follower stress appraisal and job performance. Academy of Management Journal, 59(3), 1036-1059.

Li, C., Liang, J., \& Farh, J. L. (2018). Speaking Up When Water Is Murky: An UncertaintyBased Model Linking Perceived Organizational Politics to Employee Voice. Journal of Management, (201809). doi:10.1177/0149206318798025

Li, A. N., Liao, H., Tangirala, S., \& Firth, B. M. (2017). The content of the message matters: The differential effects of promotive and prohibitive team voice on team productivity and safety performance gains. Journal of Applied Psychology, 102(8), 1259-1270. 
Liang, J., Farh, C. I., \& Farh, J.-L. (2012). Psychological antecedents of promotive and prohibitive voice: A two-wave examination. Academy of Management Journal, 55(1), 7192.

Lin, S. H. J., \& Johnson, R. E. (2015). A suggestion to improve a day keeps your depletion away: Examining promotive and prohibitive voice behaviors within a regulatory focus and ego depletion framework. Journal of Applied Psychology, 100(5), 1381-1397.

Liu, Y., Ferris, G. R., Zinko, R., Perrewé, P. L., Weitz, B., \& Xu, J. (2007). Dispositional antecedents and outcomes of political skill in organizations: A four-study investigation with convergence. Journal of Vocational Behavior, 71(1), 146-165.

Liu, W., Tangirala, S., Lam, W., Chen, Z., Jia, R. T., \& Huang, X. (2015). How and when peers' positive mood influences employees' voice. Journal of Applied Psychology, 100(3), 976989.

Liu, W., Tangirala, S., \& Ramanujam, R. (2013). The relational antecedents of voice targeted at different leaders. Journal of Applied Psychology, 98(5), 841-851.

Liu, Y., Wang, M., Chang, C. H., Shi, J., Zhou, L., \& Shao, R. (2015). Work-family conflict, emotional exhaustion, and displaced aggression toward others: The moderating roles of workplace interpersonal conflict and perceived managerial family support. Journal of Applied Psychology, 100(3), 793-808.

Liu, W., Zhu, R., \& Yang, Y. (2010). I warn you because I like you: Voice behavior, employee identifications, and transformational leadership. Leadership Quarterly, 21(1), 189-202.

Lu, S., Bartol, K. M., Venkataramani, V., Zheng, X., \& Liu, X. (2019). Pitching novel ideas to the boss: The interactive effects of employees' idea enactment and influence tactics on 
creativity assessment and implementation. Academy of Management Journal, 62(2), 579606.

MacKenzie, S. B., Podsakoff, P. M., \& Ahearne, M. (1998). Some possible antecedents and consequences of in-role and extra-role salesperson performance. Journal of Marketing, 62(3), 87-98.

MacKinnon, D. P., Lockwood, C. M., \& Williams, J. (2004). Confidence limits for the indirect effect: Distribution of the product and resampling methods. Multivariate Behavioral Research, 39(1), 99-128.

Maynes, T. D., \& Podsakoff, P. M. (2014). Speaking more broadly: An examination of the nature, antecedents, and consequences of an expanded set of employee voice behaviors. Journal of Applied Psychology, 99(1), 87-112.

McCabe, D. M., \& Lewin, D. (1992). Employee voice: A human resource management perspective. California Management Review, 34(3), 112-123.

McClean, E. J., Burris, E. R., \& Detert, J. R. (2013). When does voice lead to exit? It depends on leadership. Academy of Management journal, 56(2), 525-548.

McClean, E., Martin, S. R., Emich, K., \& Woodruff, T. (2018). The social consequences of voice: An examination of voice type and gender on status and subsequent leader emergence. Academy of Management Journal, 61(5), 1869-1891.

Menon, T., Thompson, L., \& Choi, H. S. (2006). Tainted knowledge vs. tempting knowledge: People avoid knowledge from internal rivals and seek knowledge from external rivals. Management Science, 52(8), 1129-1144.

Mitchell, T. R., \& James, L. R. (2001). Building better theory: Time and the specification of when things happen. Academy of Management Review, 26(4), 530-547. 
Morrison, E. W. (2014). Employee voice and silence. Annual Review of Organizational Psychology and Organizational Behavior, 1(1), 173-197.

Morrison, E. W. (2011). Employee voice behavior: Integration and directions for future research. Academy of Management Annals, 5(1), 373-412.

Morrison, E. W., See, K. E., \& Pan, C. (2015). An approach-inhibition model of employee silence: The joint effects of personal sense of power and target openness. Personnel Psychology, 68(3), 547-580.

Morrison, E. W., Chen, Y. R., \& Salgado, S. R. (2004). Cultural differences in newcomer feedback seeking: A comparison of the United States and Hong Kong. Applied Psychology, 53(1), 1-22.

Morrison, E. W., \& Milliken, F. J. (2000). Organizational silence: A barrier to change and development in a pluralistic world. Academy of Management Review, 25(4), 706-725.

Morrison, E. W., \& Phelps, C. C. (1999). Taking charge at work: Extrarole efforts to initiate workplace change. Academy of Management Journal, 42(4), 403-419.

Morrison, E. W., Wheeler-Smith, S. L., \& Kamdar, D. (2011). Speaking up in groups: a crosslevel study of group voice climate and voice. Journal of Applied Psychology, 96(1), 183191.

Motowidlo, S. J. (2003). Job performance. In W. C. Borman, D. R. Ilgen, \& R. J. Klimoski (Eds.), Handbook of psychology: Industrial and organizational psychology, Vol. 12: Industrial and organizational psychology (pp. 39 -53). Hoboken, NJ: John Wiley \& Sons. 
Motowidlo, S. J., \& Van Scotter, J. R. (1994). Evidence that task performance should be distinguished from contextual performance. Journal of Applied Psychology, 79(4), 475480.

Motowildo, S. J., Borman, W. C., \& Schmit, M. J. (1997). A theory of individual differences in task and contextual performance. Human Performance, 10(2), 71-83.

Mowbray, P. K., Wilkinson, A., \& Tse, H. H. (2015). An integrative review of employee voice: Identifying a common conceptualization and research agenda. International Journal of Management Reviews, 17(3), 382-400.

Muethel, M., Gehrlein, S., \& Hoegl, M. (2012). Socio-demographic factors and shared leadership behaviors in dispersed teams: Implications for human resource management. Human Resource Management, 51(4), 525-548.

Munyon, T. P., Summers, J. K., Thompson, K. M., \& Ferris, G. R. (2015). Political skill and work outcomes: A theoretical extension, meta-analytic investigation, and agenda for the future. Personnel Psychology, 68(1), 143-184.

Muthén, L. K., \& Muthén, B. O. (2002). How to use a Monte Carlo study to decide on sample size and determine power. Structural Equation Modeling, 9(4), 599-620.

Narayanan, V. K., \& Fahey, L. (1982). The micro-politics of strategy formulation. Academy of Management Review, 7(1), 25-34.

Nisbett, R. E., \& Wilson, T. D. (1977). The halo effect: evidence for unconscious alteration of judgments. Journal of Personality and Social Psychology, 35(4), 250-256.

Ohly, S., \& Fritz, C. (2007). Challenging the status quo: What motivates proactive behaviour? Journal of Occupational and Organizational Psychology, 80(4), 623-629.

Organ, D. W. (1988). Organizational Citizenship Behavior, Lexington, Lexington, MA. 
Organ, D. W. (1990). The subtle significance of job satisfaction. Clinical Laboratory Management Review, 4, 94-98.

Parker, S. K., Bindl, U. K., \& Strauss, K. (2010). Making things happen: A model of proactive motivation. Journal of Management, 36(4), 827-856.

Parker, S. K., \& Collins, C. G. (2010). Taking stock: Integrating and differentiating multiple proactive behaviors. Journal of Management, 36(3), 633-662.

Parker, S. K., Williams, H. M., \& Turner, N. (2006). Modeling the antecedents of proactive behavior at work. Journal of Applied Psychology, 91(3), 636-652.

Penner, L. A., Dovidio, J. F., Piliavin, J. A., \& Schroeder, D. A. (2005). Prosocial behavior: Multilevel perspectives. Annual Review of Psychology, 56, 365-392.

Pfeffer, J. (2010). Building sustainable organizations: The human factor. Academy of Management perspectives, 24(1), 34-45.

Podsakoff, P. M., \& MacKenzie, S. B. (1997). Impact of organizational citizenship behavior on organizational performance: A review and suggestion for future research. Human performance, $10(2), 133-151$.

Podsakoff, P. M., MacKenzie, S. B., Lee, J. Y., \& Podsakoff, N. P. (2003). Common method biases in behavioral research: a critical review of the literature and recommended remedies. Journal of Applied Psychology, 88(5), 879-903.

Podsakoff, P. M., MacKenzie, S. B., \& Podsakoff, N. P. (2012). Sources of method bias in social science research and recommendations on how to control it. Annual Review of Psychology, 63(1), 539-569. 
Podsakoff, P. M., MacKenzie, S. B., Moorman, R. H., \& Fetter, R. (1990). Transformational leader behaviors and their effects on followers' trust in leader, satisfaction, and organizational citizenship behaviors. Leadership Quarterly, 1(2), 107-142.

Podsakoff, P. M., MacKenzie, S. B., Paine, J. B., \& Bachrach, D. G. (2000). Organizational citizenship behaviors: A critical review of the theoretical and empirical literature and suggestions for future research. Journal of Management, 26(3), 513-563.

Podsakoff, N. P., Whiting, S. W., Podsakoff, P. M., \& Blume, B. D. (2009). Individual-and organizational-level consequences of organizational citizenship behaviors: A metaanalysis. Journal of applied Psychology, 94(1), 122-141.

Porter, L. W., \& Schneider, B. (2014). What was, what is, and what may be in OP/OB. Annual Review of Organizational Psychology and Organizational Behavior, 1(1), 1-21.

Preacher, K. J., Curran, P. J., \& Bauer, D. J. (2006). Computational tools for probing interactions in multiple linear regression, multilevel modeling, and latent curve analysis. Journal of Educational and Behavioral Statistics, 31(4), 437-448.

Preacher, K. J., Rucker, D. D., \& Hayes, A. F. (2007). Addressing moderated mediation hypotheses: Theory, methods, and prescriptions. Multivariate Behavioral Research, 42(1), 185-227.

Pyszczynski, T. A., \& Greenberg, J. (1981). Role of disconfirmed expectancies in the instigation of attributional processing. Journal of Personality and Social Psychology, 40(1), 31-38.

Rank, J., Carsten, J. M., Unger, J. M., \& Spector, P. E. (2007). Proactive customer service performance: Relationships with individual, task, and leadership variables. Human Performance, 20(4), 363-390. 
Rank, J., Nelson, N. E., Allen, T. D., \& Xu, X. (2009). Leadership predictors of innovation and task performance: Subordinates' self-esteem and self-presentation as moderators. Journal of Occupational and Organizational Psychology, 82(3), 465-489.

Rank, J., Pace, V. L., \& Frese, M. (2004). Three avenues for future research on creativity, innovation, and initiative. Applied Psychology, 53(4), 518-528.

Reeder, G. D., Pryor, J. B., Wohl, M. J., \& Griswell, M. L. (2005). On attributing negative motives to others who disagree with our opinions. Personality and Social Psychology Bulletin, 31(11), 1498-1510.

Restubog, S. L. D., Scott, K. L., \& Zagenczyk, T. J. (2011). When distress hits home: the role of contextual factors and psychological distress in predicting employees' responses to abusive supervision. Journal of Applied Psychology, 96(4), 713-729.

Riordan, C. M. (2000). Relational demography within groups: Past developments, contradictions, and new directions. In Research in personnel and human resources management (pp. 131-173). Emerald Group Publishing Limited.

Rioux, S. M., \& Penner, L. A. (2001). The causes of organizational citizenship behavior: a motivational analysis. Journal of Applied Psychology, 86(6), 1306-1314.

Rusbult, C. E., Farrell, D., Rogers, G., \& Mainous, A. G. (1988). Impact of exchange variables on exit, voice, loyalty, and neglect: An integrative model of responses to declining job satisfaction. Academy of Management Journal, 31(3), 599-627.

Salamon, S. D., \& Deutsch, Y. (2006). OCB as a handicap: An evolutionary psychological perspective. Journal of Organizational Behavior, 27(2), 185-199. 
Schaubroeck, J. M., Shen, Y., \& Chong, S. (2017). A dual-stage moderated mediation model linking authoritarian leadership to follower outcomes. Journal of Applied Psychology, 102(2), 203-214.

Scott, S. G., \& Bruce, R. A. (1994). Determinants of innovative behavior: A path model of individual innovation in the workplace. Academy of Management journal, 37(3), 580607.

Siemsen, E., Roth, A., \& Oliveira, P. (2010). Common method bias in regression models with linear, quadratic, and interaction effects. Organizational Research Methods, 13(3), 456476.

Seibert, S. E., Kraimer, M. L., \& Crant, J. M. (2001). What do proactive people do? A longitudinal model linking proactive personality and career success. Personnel psychology, 54(4), 845-874.

Semadar, A., Robins, G., \& Ferris, G. R. (2006). Comparing the validity of multiple social effectiveness constructs in the prediction of managerial job performance. Journal of Organizational Behavior: The International Journal of Industrial, Occupational and Organizational Psychology and Behavior, 27(4), 443-461.

Smith, A. D., Plowman, D. A., Duchon, D., \& Quinn, A. M. (2009). A qualitative study of highreputation plant managers: Political skill and successful outcomes. Journal of Operations Management, 27(6), 428-443.

Snijders, T., \& Bosker, R. (2012). Multilevel analysis. London, UK: Sage.

Sober, E., \& Wilson, D.S. (1998). Unto others: The evolution and psychology of unselfish behavior. Cambridge, MA: Harvard University Press. 
Steelman, L. A., \& Rutkowski, K. A. (2004). Moderators of employee reactions to negative feedback. Journal of Managerial Psychology, 19(1), 6-18.

Tangirala, S., Kamdar, D., Venkataramani, V., \& Parke, M. R. (2013). Doing right versus getting ahead: The effects of duty and achievement orientations on employees' voice. Journal of Applied Psychology, 98(6), 1040-1050.

Tangirala, S., \& Ramanujam, R. (2012). Ask and you shall hear (but not always): Examining the relationship between manager consultation and employee voice. Personnel Psychology, $65(2), 251-282$.

Tepper, B. J., Moss, S. E., \& Duffy, M. K. (2011). Predictors of abusive supervision: Supervisor perceptions of deep-level dissimilarity, relationship conflict, and subordinate performance. Academy of Management Journal, 54(2), 279-294.

Thibaut, J. W., \& Walker, L. (1975). Procedural justice: A psychological analysis. Hillsdale, NJ: Erlbaum.

Thibaut, J. W., \& Kelley, H. H. (1959). Power and dependence. In J. W. Thibaut \& H. H. Kelley (Eds.), The social psychology of groups (pp. 100-125). New York, NY: Wiley.

Treadway, D. C., Ferris, G. R., Duke, A. B., Adams, G. L., \& Thatcher, J. B. (2007). The moderating role of subordinate political skill on supervisors' impressions of subordinate ingratiation and ratings of subordinate interpersonal facilitation. Journal of Applied Psychology, 92(3), 848-855.

Trivers, R. L. (1971). The evolution of reciprocal altruism. The Quarterly Review of Biology, 46(1), 35-57. 
Tsui, A. S., \& O'reilly III, C. A. (1989). Beyond simple demographic effects: The importance of relational demography in superior-subordinate dyads. Academy of Management Journal, $32(2), 402-423$.

Tuckey, M., Brewer, N., \& Williamson, P. (2002). The influence of motives and goal orientation on feedback seeking. Journal of Occupational and Organizational Psychology, 75(2), 195-216.

Van Dyne, L., Ang, S., \& Botero, I. C. (2003). Conceptualizing employee silence and employee voice as multidimensional constructs. Journal of Management Studies, 40(6), 1359-1392.

Van Dyne, L., Graham, J. W., \& Dienesch, R. M. (1994). Organizational citizenship behavior: Construct redefinition, measurement, and validation. Academy of Management journal, $37(4), 765-802$.

Van Dyne, L., Kamdar, D., \& Joireman, J. (2008). In-role perceptions buffer the negative impact of low LMX on helping and enhance the positive impact of high LMX on voice. Journal of Applied Psychology, 93(6), 1195-1207.

Van Dyne, L., \& LePine, J. A. (1998). Helping and voice extra-role behaviors: Evidence of construct and predictive validity. Academy of Management Journal, 41(1), 108-119.

Venkataramani, V., \& Tangirala, S. (2010). When and why do central employees speak up? An examination of mediating and moderating variables. Journal of Applied Psychology, $95(3), 582-591$.

Vroom, V. (1964). Work and Motivation. New York: Wiley.

Walumbwa, F. O., \& Schaubroeck, J. (2009). Leader personality traits and employee voice behavior: mediating roles of ethical leadership and work group psychological safety. Journal of Applied Psychology, 94(5), 1275-1286. 
Ward, A. K., Ravlin, E. C., Klaas, B. S., Ployhart, R. E., \& Buchan, N. R. (2016). When do highcontext communicators speak up? Exploring contextual communication orientation and employee voice. Journal of Applied Psychology, 101(10), 1498-1511.

Wei, X., Zhang, Z. X., \& Chen, X. P. (2015). I will speak up if my voice is socially desirable: A moderated mediating process of promotive versus prohibitive voice. Journal of Applied Psychology, 100(5), 1641-1652.

Weiner, B. (1980). A cognitive (attribution)-emotion-action model of motivated behavior: An analysis of judgments of help-giving. Journal of Personality and Social Psychology, 39(2), 186-200.

Whiting, S. W., Maynes, T. D., Podsakoff, N. P., \& Podsakoff, P. M. (2012). Effects of message, source, and context on evaluations of employee voice behavior. Journal of Applied Psychology, 97(1), 159-182.

Whitmeyer, J. M. (2000). Effects of positive reputation systems. Social Science Research, 29(2), $188-207$.

Williams, S. D. (2002). Self-esteem and the self-censorship of creative ideas. Personnel Review, $31(4), 495-503$.

Williams, L. J., \& Anderson, S. E. (1991). Job satisfaction and organizational commitment as predictors of organizational citizenship and in-role behaviors. Journal of Management, 17(3), 601-617.

Wilson, K. S., Sin, H. P., \& Conlon, D. E. (2010). What about the leader in leader-member exchange? The impact of resource exchanges and substitutability on the leader. Academy of Management Review, 35(3), 358-372. 
Witt, L., \& Ferris, G. R. (2003). Social skill as moderator of the conscientiousness-performance relationship: Convergent results across four studies. Journal of Applied Psychology, $88(5), 809-820$.

Wang, D., Waldman, D. A., \& Zhang, Z. (2014). A meta-analysis of shared leadership and team effectiveness. Journal of Applied Psychology, 99(2), 181-198.

Williams, L. J., \& Anderson, S. E. (1991). Job satisfaction and organizational commitment as predictors of organizational citizenship and in-role behaviors. Journal of Management, $17(3), 601-617$.

Yam, K. C., Klotz, A. C., He, W., \& Reynolds, S. J. (2017). From good soldiers to psychologically entitled: Examining when and why citizenship behavior leads to deviance. Academy of Management Journal, 60(1), 373-396.

Yuan, F., \& Woodman, R. W. (2010). Innovative behavior in the workplace: The role of performance and image outcome expectations. Academy of Management Journal, 53(2), 323-342.

Yukl, G. (1982). Managerial Leadership and the Effective Principal.

Yukl, G. (1989). Managerial leadership: A review of theory and research. Journal of Management, 15(2), 251-289.

Zhang, Y., LePine, J. A., Buckman, B. R., \& Wei, F. (2014). It's not fair... or is it? The role of justice and leadership in explaining work stressor-job performance relationships. Academy of Management Journal, 57(3), 675-697.

Zhang, Z., Wang, M. O., \& Shi, J. (2012). Leader-follower congruence in proactive personality and work outcomes: The mediating role of leader-member exchange. Academy of Management Journal, 55(1), 111-130. 
Zhou, J., \& George, J. M. (2001). When job dissatisfaction leads to creativity: Encouraging the expression of voice. Academy of Management Journal, 44(4), 682-696.

Zinko, R., Ferris, G. R., Blass, F. R., \& Dana Laird, M. (2007). Toward a theory of reputation in organizations. In Research in Personnel and Human Resources Management (pp. 163204). Emerald Group Publishing Limited.

Zinko, R., Ferris, G. R., Humphrey, S. E., Meyer, C. J., \& Aime, F. (2012). Personal reputation in organizations: Two-study constructive replication and extension of antecedents and consequences. Journal of Occupational and Organizational Psychology, 85(1), 156-180. 
Table 1. Voice Behavior Definitions

\begin{tabular}{|c|c|c|c|c|c|}
\hline $\begin{array}{c}\text { Voice in Various } \\
\text { Literatures }\end{array}$ & Study & Definition & Key Attributes & $\begin{array}{c}\text { Selected } \\
\text { Empirical Studies }\end{array}$ & Measure \\
\hline Labor Relation & $\begin{array}{l}\text { Hirschman } \\
\text { (1970) }\end{array}$ & $\begin{array}{l}\text { Voice: “... any attempt at all } \\
\text { to change, rather than to } \\
\text { escape from, an objectionable } \\
\text { state of affairs, whether } \\
\text { through individual or } \\
\text { collective petition to the } \\
\text { management directly in } \\
\text { charge, through appeal to a } \\
\text { higher authority with intention } \\
\text { of forcing a change in } \\
\text { management, or through } \\
\text { various types of actions or } \\
\text { protests, including those that } \\
\text { are meant to mobilize public } \\
\text { opinion" (p. 30) }\end{array}$ & $\begin{array}{l}\text { Individual or collective } \\
\text { change-oriented } \\
\text { behaviors, including } \\
\text { making suggestions to } \\
\text { change, filing grievance } \\
\text { (through a formal } \\
\text { system), and whistle- } \\
\text { blowing, etc. }\end{array}$ & $\begin{array}{l}\text { Farrell (1983); } \\
\text { Rusbult et al. } \\
\text { (1988); Trunley et } \\
\text { al. (1999); Withey } \\
\text { \& Cooper (1989) }\end{array}$ & $\begin{array}{l}\text { Sample items: } \\
\text { 1. } \ldots \text { goes to the } \\
\text { supervisor to } \\
\text { discuss the } \\
\text { problem... } \\
\text { 2. } \\
\text {... solves the } \\
\text { problem by } \\
\text { making } \\
\text { suggestions ... } \\
\text { 3. } \\
\text {... contacts an } \\
\text { outside agency } \\
\text { (e.g., union) to get } \\
\text { help. }\end{array}$ \\
\hline
\end{tabular}




\begin{tabular}{|c|c|c|c|c|c|}
\hline $\begin{array}{c}\text { Voice in Various } \\
\text { Literatures }\end{array}$ & Study & Definition & Key Attributes & $\begin{array}{c}\text { Selected } \\
\text { Empirical Studies }\end{array}$ & Measure \\
\hline \multirow[t]{4}{*}{ Labor Relation } & Gordan (1988) & $\begin{array}{l}\text { Active \& Construct Voice: } \\
\text { "behaviors include making } \\
\text { suggestions, bolsterism } \\
\text { (supporting the status quo), } \\
\text { and principled dissent" (p. } \\
\text { 285) }\end{array}$ & $\begin{array}{l}\text { Expressing opinions } \\
\text { either supporting the } \\
\text { change or supporting the } \\
\text { status quo }\end{array}$ & N.A. & N.A. \\
\hline & & $\begin{array}{l}\text { Active \& Destructive Voice: } \\
\text { "behaviors include verbal } \\
\text { aggression, bad-mouthing, and } \\
\text { antagonistic exit (p. 285) }\end{array}$ & $\begin{array}{l}\text { Deviant or } \\
\text { counterproductive } \\
\text { behavior }\end{array}$ & & \\
\hline & & $\begin{array}{l}\text { Passive \& Constructive } \\
\text { Voice: "behaviors include } \\
\text { nonverbal support, } \\
\text { compliance, and cooperation } \\
\text { (p. } 258 \text { ) }\end{array}$ & $\begin{array}{l}\text { Being compliant and } \\
\text { cooperative }\end{array}$ & & \\
\hline & & $\begin{array}{l}\text { Passive \& Destructive Voice: } \\
\text { "behaviors include apathy, } \\
\text { calculated silence, and } \\
\text { withdrawal (p. 285) }\end{array}$ & $\begin{array}{l}\text { Withdrawal behavior, } \\
\text { silence }\end{array}$ & & \\
\hline
\end{tabular}




\begin{tabular}{lllll}
\hline $\begin{array}{l}\text { Voice in Various } \\
\text { Literatures }\end{array}$ & \multicolumn{1}{c}{ Study } & \multicolumn{1}{c}{ Definition } & Key Attributes & \multicolumn{1}{c}{$\begin{array}{c}\text { Selected } \\
\text { Empirical Studies }\end{array}$} \\
\hline Labor Relation & $\begin{array}{l}\text { McCabe \& Lewin } \\
(1992)\end{array}$ & $\begin{array}{l}\text { Voice: "involves the } \\
\text { expression by employees to } \\
\text { management of their } \\
\text { complains in a work-related } \\
\text { context", and also "involves } \\
\text { the participation of employees } \\
\text { in the decision-making } \\
\text { processes of business } \\
\text { organizations" (p. 112) }\end{array}$ & $\begin{array}{l}\text { Complaints and } \\
\text { participation }\end{array}$ & N.A. \\
& &
\end{tabular}

\begin{tabular}{|c|c|c|c|c|c|}
\hline $\begin{array}{l}\text { Labor Relation, } \\
\text { Procedural Justice }\end{array}$ & $\begin{array}{l}\text { Brockner et al. } \\
(1998)\end{array}$ & $\begin{array}{l}\text { Voice: "define employee voice } \\
\text { as any type of mechanism, } \\
\text { structure or practice, which } \\
\text { provides an employee with an } \\
\text { opportunity to express an } \\
\text { opinion or participate in } \\
\text { decision-making within their } \\
\text { organization" (p. 396) }\end{array}$ & $\begin{array}{l}\text { Employee participation, } \\
\text { engagement, } \\
\text { empowerment }\end{array}$ & $\begin{array}{l}\text { Brockner et al. } \\
\text { (1998); Lavelle et } \\
\text { al. (2010); Pyman } \\
\text { et al. (2006) }\end{array}$ & $\begin{array}{l}\text { Sample items: } \\
\text { Before ... decision is } \\
\text { announced } \\
\text { 1. How much } \\
\text { opportunity did } \\
\text { you have to } \\
\text { persuade } \\
\text { management to do } \\
\text { (or not to do) ...? } \\
\text { 2. To what extent did } \\
\text { you have the } \\
\text { opportunity to } \\
\text { express your } \\
\text { viewpoints to } \\
\text { management? }\end{array}$ \\
\hline
\end{tabular}




\begin{tabular}{|c|c|c|c|c|c|}
\hline $\begin{array}{l}\text { Voice in Various } \\
\text { Literatures }\end{array}$ & Study & Definition & Key Attributes & $\begin{array}{c}\text { Selected } \\
\text { Empirical Studies }\end{array}$ & Measure \\
\hline $\begin{array}{l}\text { Organizational } \\
\text { Behavior }\end{array}$ & $\begin{array}{l}\text { Van Dyne \& } \\
\text { LePine (1998) }\end{array}$ & $\begin{array}{l}\text { Voice: "promotive behavior } \\
\text { that emphasizes the expression } \\
\text { of constructive challenge } \\
\text { intended to improve rather } \\
\text { than merely criticize" (p. 109) }\end{array}$ & $\begin{array}{l}\text { Discretionary, } \\
\text { suggestion-based, } \\
\text { challenging the status } \\
\text { quo, aiming for } \\
\text { improvement }\end{array}$ & $\begin{array}{l}\text { This is the } \\
\text { prevalent } \\
\text { conceptualization } \\
\text { of voice adopted } \\
\text { by most of voice } \\
\text { studies in the field } \\
\text { of organizational } \\
\text { behavior. For } \\
\text { example, Burris } \\
\text { (2012); Fast et al. } \\
(2014) ; \text { Howell et } \\
\text { al., (2015), etc. }\end{array}$ & $\begin{array}{l}\text { Sample items: } \\
\text { 1. } \ldots \text { develops and } \\
\text { makes } \\
\text { recommendations } \\
\text { concerning issues } \\
\text { that affect this } \\
\text { work group. } \\
\text { 2. } \ldots \text { keeps well } \\
\text { informed about } \\
\text { issues where } \\
\text { his/her opinion } \\
\text { might be useful. } \\
\text { 3. speaks up with } \\
\text { ideas for new } \\
\text { projects or changes } \\
\text { in the current } \\
\text { procedures. }\end{array}$ \\
\hline \multirow[t]{2}{*}{$\begin{array}{l}\text { Organizational } \\
\text { Behavior }\end{array}$} & \multirow[t]{2}{*}{ Burris (2012) } & $\begin{array}{l}\text { Challenging voice: a } \\
\text { proactive behavior "speaking } \\
\text { up in ways intended to alter, } \\
\text { modify, or destabilize } \\
\text { generally accepted sets of } \\
\text { practices, policies or strategic } \\
\text { directions that make up the } \\
\text { status quo..." (p. 852) }\end{array}$ & $\begin{array}{l}\text { Challenging voice: } \\
\text { equivalent to voice } \\
\text { defined by Van Dyne \& } \\
\text { LePine (1998) }\end{array}$ & \multirow[t]{2}{*}{ N.A. } & $\begin{array}{l}\text { Burris revised Van Dyne } \\
\text { \& LePine's (1998) 6-item } \\
\text { measure, and grouped the } \\
\text { revised items into two 3- } \\
\text { item measures } \\
\text { representing challenging } \\
\text { and supportive voice } \\
\text { respectively: }\end{array}$ \\
\hline & & $\begin{array}{l}\text { Supportive voice: a reactive } \\
\text { behavior "intended to stabilize } \\
\text { or preserve existing } \\
\text { organizational policies or } \\
\text { practices" (p. } 853 \text { ) }\end{array}$ & $\begin{array}{l}\text { Supportive voice: } \\
\text { supportive to the status } \\
\text { quo and defend against } \\
\text { any criticism or challenge } \\
\text { to the status quo }\end{array}$ & & $\begin{array}{l}\text { Sample items of } \\
\text { challenging voice: } \\
\text { 1. I give suggestions } \\
\text { to my District } \\
\text { Manager about }\end{array}$ \\
\hline
\end{tabular}




\begin{tabular}{|c|c|c|c|c|c|}
\hline $\begin{array}{c}\text { Voice in Various } \\
\text { Literatures }\end{array}$ & Study & Definition & Key Attributes & $\begin{array}{c}\text { Selected } \\
\text { Empirical Studies }\end{array}$ & Measure \\
\hline & & & & & $\begin{array}{l}\text { how to make this } \\
\text { restaurant better... } \\
\text { 2. I speak up to my } \\
\text { District Manager } \\
\text { with ideas to } \\
\text { address } \\
\text { employees' needs } \\
\text { and concerns. } \\
\text { Sample items of } \\
\text { supportive voice: } \\
\text { 1. I keep well- } \\
\text { informed about } \\
\text { issues where my } \\
\text { opinion might be } \\
\text { helpful. } \\
\text { 2. I speak up and } \\
\text { encourage others } \\
\text { to get involved in } \\
\text { issues that affect } \\
\text { this organization. }\end{array}$ \\
\hline $\begin{array}{l}\text { Organizational } \\
\text { Behavior }\end{array}$ & $\begin{array}{l}\text { Liang et al. } \\
(2012)\end{array}$ & $\begin{array}{l}\text { Promotive voice: "employees' } \\
\text { expression of new ideas or } \\
\text { suggestions for improving the } \\
\text { overall functioning of their } \\
\text { work unit or organization" (p. } \\
75)\end{array}$ & $\begin{array}{l}\text { Promotive voice defined } \\
\text { by Liang et al. (2012) is } \\
\text { equivalent to voice } \\
\text { defined by Van Dyne \& } \\
\text { LePine (1998) }\end{array}$ & $\begin{array}{l}\text { Hsiung \& Tsai } \\
\text { (2017); Kakkar et } \\
\text { al. (2016); Ward et } \\
\text { al. (2016); Wei et } \\
\text { al. (2015) }\end{array}$ & $\begin{array}{l}\text { Sample items: } \\
\text { Promotive voice: } \\
\begin{array}{ll}\text { 1. } & \text {..raises } \\
& \text { suggestions to } \\
& \text { improve the unit's } \\
& \text { working } \\
\text { procedure. } \\
\text { 2. } & \text {... makes } \\
& \text { constructive } \\
\text { suggestions to }\end{array}\end{array}$ \\
\hline
\end{tabular}




\begin{tabular}{|c|c|c|c|c|c|}
\hline $\begin{array}{c}\text { Voice in Various } \\
\text { Literatures }\end{array}$ & Study & Definition & Key Attributes & $\begin{array}{c}\text { Selected } \\
\text { Empirical Studies }\end{array}$ & Measure \\
\hline & & & & & $\begin{array}{l}\text { improve the unit's } \\
\text { operation. }\end{array}$ \\
\hline & & $\begin{array}{l}\text { Prohibitive voice: } \\
\text { "employees' expression of } \\
\text { concern about work practices, } \\
\text { incidents, or employee } \\
\text { behavior that are harmful to } \\
\text { their organization" (p. 75) }\end{array}$ & $\begin{array}{l}\text { Prohibitive voice with a } \\
\text { focus on pointing out the } \\
\text { past or current errors or } \\
\text { problems, preventing } \\
\text { problematic initiatives } \\
\text { from being implemented, } \\
\text { not suggestion-based } \\
\text { towards a future ideal } \\
\text { state }\end{array}$ & & $\begin{array}{l}\text { Prohibitive voice: } \\
\text { 1. } \ldots \text { speaks up } \\
\text { honestly with } \\
\text { problems that } \\
\text { might cause } \\
\text { serious loss the } \\
\text { work unit. } \\
\text { 2. } \ldots \text { reports } \\
\text { coordination } \\
\text { problems in the } \\
\text { workplace. }\end{array}$ \\
\hline $\begin{array}{l}\text { Organizational } \\
\text { Behavior }\end{array}$ & $\begin{array}{l}\text { Maynes \& } \\
\text { Podsakoff (2014) }\end{array}$ & $\begin{array}{l}\text { Supportive voice: “... the } \\
\text { voluntary expression of } \\
\text { support for worthwhile work- } \\
\text { related policies and } \\
\text { procedures, or speaking out in } \\
\text { defense of these same things } \\
\text { when they are being unfairly } \\
\text { criticized" (p. 5) }\end{array}$ & $\begin{array}{l}\text { Supportive voice: highly } \\
\text { supportive to the status } \\
\text { quo and defend against } \\
\text { any criticism or challenge } \\
\text { to the status quo }\end{array}$ & N.A. & $\begin{array}{l}\text { Sample items: } \\
\text { Supportive voice: } \\
\text { 1. } \ldots \text { defends } \\
\text { organizational } \\
\text { programs when } \\
\text { others unfairly } \\
\text { criticize. } \\
\text { 2. } \\
\text {... speaks up in } \\
\text { support of } \\
\text { organizational } \\
\text { policies that have } \\
\text { merit when others } \\
\text { raise unjustified } \\
\text { concerns about the } \\
\text { policies. }\end{array}$ \\
\hline
\end{tabular}




\begin{tabular}{|c|c|c|c|c|c|}
\hline $\begin{array}{c}\text { Voice in Various } \\
\text { Literatures }\end{array}$ & Study & Definition & Key Attributes & $\begin{array}{c}\text { Selected } \\
\text { Empirical Studies }\end{array}$ & Measure \\
\hline & & $\begin{array}{l}\text { Constructive voice: "... the } \\
\text { voluntary expression of ideas, } \\
\text { information, or opinions } \\
\text { focused on effecting } \\
\text { organizationally functional } \\
\text { change to the work context" } \\
\text { (p. 5) }\end{array}$ & $\begin{array}{l}\text { Constructive voice } \\
\text { defined by Maynes \& } \\
\text { Podsakoff. (2014) is } \\
\text { equivalent to voice } \\
\text { defined by Van Dyne \& } \\
\text { LePine (1998) }\end{array}$ & & $\begin{array}{l}\text { Constructive voice: } \\
\text { 1. } \ldots \text { makes } \\
\text { suggestions about } \\
\text { how to do things in } \\
\text { new or more } \\
\text { effective ways at } \\
\\
\text { work. } \\
\text { 2. } \\
\text {.. often suggests } \\
\text { changes to work } \\
\text { projects in order to } \\
\text { make them better. }\end{array}$ \\
\hline & & $\begin{array}{l}\text { Defensive voice: “... the } \\
\text { voluntary expression of } \\
\text { opposition to changing an } \\
\text { organization's policies, ... } \\
\text { even when the proposed } \\
\text { changes have merit or making } \\
\text { changes is necessary" (p. 5) }\end{array}$ & $\begin{array}{l}\text { Defensive voice: resistant } \\
\text { to any change regardless } \\
\text { of its necessity }\end{array}$ & & $\begin{array}{l}\text { Defensive voice: } \\
\text { 1. } \ldots \text { speaks out } \\
\text { against changing } \\
\text { work policies, } \\
\text { even when making } \\
\text { changes would be } \\
\text { for the best. } \\
\text { 2. } \ldots \text { argues against } \\
\text { changing work } \\
\text { methods even } \\
\text { when the proposed } \\
\text { changes have } \\
\text { merit. }\end{array}$ \\
\hline & & $\begin{array}{l}\text { Destructive voice: “... the } \\
\text { voluntary expression of } \\
\text { hurtful, critical, or debasing }\end{array}$ & $\begin{array}{l}\text { Destructive voice: merely } \\
\text { criticism or complain } \\
\text { without any }\end{array}$ & & $\begin{array}{l}\text { Destructive voice: } \\
\text { 1. ... bad-mouths the } \\
\text { organization's }\end{array}$ \\
\hline
\end{tabular}




\begin{tabular}{|c|c|c|c|c|c|}
\hline $\begin{array}{c}\text { Voice in Various } \\
\text { Literatures }\end{array}$ & Study & Definition & Key Attributes & $\begin{array}{c}\text { Selected } \\
\text { Empirical Studies }\end{array}$ & Measure \\
\hline & & $\begin{array}{l}\text { opinions regarding work } \\
\text { policies ..." }\end{array}$ & $\begin{array}{l}\text { Support/loyalty or } \\
\text { suggestion for } \\
\text { improvement }\end{array}$ & & 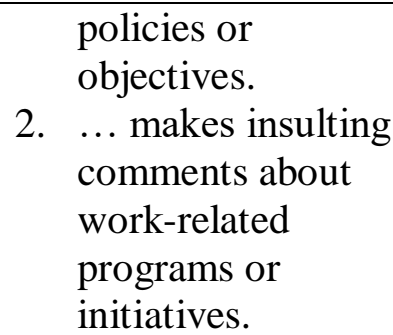 \\
\hline
\end{tabular}


Table 2. Voice Behavior Studies in Chronological Order ${ }^{1}$

\begin{tabular}{|c|c|c|c|c|c|}
\hline Year & Author(s) & DV(s) & IV(s) & Mediator(s) & Moderator(s) \\
\hline 1998 & $\begin{array}{l}\text { LePine \& Van } \\
\text { Dyne }\end{array}$ & Employee voice to peer & $\begin{array}{l}\text { Person (i.e., employee } \\
\text { satisfaction with the } \\
\text { group, self-efficacy) }\end{array}$ & N.A. & $\begin{array}{l}\text { Situation (group size, } \\
\text { management style) }\end{array}$ \\
\hline 2001 & $\begin{array}{l}\text { LePine \& Van } \\
\text { Dyne }\end{array}$ & $\begin{array}{l}\text { Employee challenging } \\
\text { and change-oriented } \\
\text { communication (i.e., } \\
\text { voice) and cooperative } \\
\text { communication, } \\
\text { employee task } \\
\text { performance }\end{array}$ & $\begin{array}{l}\text { Big Five personality, } \\
\text { general mental ability } \\
\text { (GMA) }\end{array}$ & N.A. & N.A. \\
\hline 2001 & Seibert et al. & $\begin{array}{l}\text { Career success (i.e., } \\
\text { salary progression, } \\
\text { promotion, career } \\
\text { satisfaction) }\end{array}$ & Proactive personality & $\begin{array}{l}\text { Voice, innovation, } \\
\text { political knowledge, } \\
\text { career initiative }\end{array}$ & N.A. \\
\hline 2007 & Detert \& Burris & $\begin{array}{l}\text { Employee voice to } \\
\text { supervisor }\end{array}$ & $\begin{array}{l}\text { Transformational } \\
\text { leadership, managerial } \\
\text { openness }\end{array}$ & $\begin{array}{l}\text { Employee psychological } \\
\text { safety }\end{array}$ & $\begin{array}{l}\text { Employee performance } \\
\text { evaluation }\end{array}$ \\
\hline 2007 & Fuller et al. & $\begin{array}{l}\text { Employee voice to } \\
\text { supervisor, employee } \\
\text { promotability }\end{array}$ & $\begin{array}{l}\text { Employee self- } \\
\text { monitoring }\end{array}$ & N.A. & $\begin{array}{l}\text { Employee past job } \\
\text { performance as } \\
\text { moderator when voice is } \\
\text { DV while employee } \\
\text { voice to supervisor as } \\
\text { moderator when }\end{array}$ \\
\hline
\end{tabular}

\footnotetext{
${ }^{1}$ Most voice research in the field of organizational behavior has used Van Dyne and LePine's (1998) conceptualization of voice behavior. However, Hsiung and Tsai (2017), McClean, Martin and Emich (2017), Kakkar, Tangirala, and Srivastava (2016), Wei, Zhang, and Chen (2015), Ward, Ravlin, Klaas, Ployhart, and Buchan (2015), and Li, Liang, and Farh (2018) used Liang, Farh, and Farh's (2012) expanded conceptualization which includes promotive and prohibitive voice behaviors.
} 


\begin{tabular}{|c|c|c|c|c|c|}
\hline Year & Author(s) & DV(s) & IV(s) & Mediator(s) & Moderator(s) \\
\hline & & & & & $\begin{array}{l}\text { employee promotability } \\
\text { is DV }\end{array}$ \\
\hline 2008 & Burris et al. & $\begin{array}{l}\text { Employee voice to } \\
\text { supervisor }\end{array}$ & $\begin{array}{l}\text { LMX and abusive } \\
\text { supervision }\end{array}$ & $\begin{array}{l}\text { Employee psychological } \\
\text { attachment and } \\
\text { detachment }\end{array}$ & N.A. \\
\hline 2008 & $\begin{array}{l}\text { Tangirala \& } \\
\text { Ramanujam }\end{array}$ & $\begin{array}{l}\text { Employee voice to } \\
\text { supervisor }\end{array}$ & $\begin{array}{l}\text { Employee personal } \\
\text { control }\end{array}$ & $\begin{array}{l}\text { Employee voice role } \\
\text { conceptualization }\end{array}$ & $\begin{array}{l}\text { Employee organizational } \\
\text { identification }\end{array}$ \\
\hline 2008 & Van Dyne et al. & $\begin{array}{l}\text { Employee helping and } \\
\text { voice }\end{array}$ & LMX & N.A. & $\begin{array}{l}\text { Employee voice and } \\
\text { helping role expectation }\end{array}$ \\
\hline 2009 & Grant et al. & $\begin{array}{l}\text { Employee performance } \\
\text { evaluation rated by } \\
\text { supervisors }\end{array}$ & $\begin{array}{l}\text { Employee proactive } \\
\text { behaviors (i.e., voice, } \\
\text { helping, taking charge, } \\
\text { issue selling) }\end{array}$ & N.A. & $\begin{array}{l}\text { Employee self-reported } \\
\text { prosocial motive and } \\
\text { negative affect }\end{array}$ \\
\hline 2009 & Grant \& Mayer & $\begin{array}{l}\text { Employee extra-role } \\
\text { behavior (i.e., helping, } \\
\text { courtesy, voice) }\end{array}$ & $\begin{array}{l}\text { Employee self-reported } \\
\text { prosocial motive }\end{array}$ & N.A. & $\begin{array}{l}\text { Employee self-reported } \\
\text { impression management } \\
\text { motive }\end{array}$ \\
\hline 2009 & $\begin{array}{l}\text { Botero \& Van } \\
\text { Dyne }\end{array}$ & Employee voice & LMX & N.A. & $\begin{array}{l}\text { Employees' beliefs of } \\
\text { power distance }\end{array}$ \\
\hline 2009 & $\begin{array}{l}\text { Walumbwa \& } \\
\text { Schaubroeck }\end{array}$ & $\begin{array}{l}\text { Employee voice to } \\
\text { supervisor }\end{array}$ & $\begin{array}{l}\text { Leader Big Five } \\
\text { personality, ethical } \\
\text { leadership }\end{array}$ & $\begin{array}{l}\text { Employee psychological } \\
\text { safety }\end{array}$ & N.A. \\
\hline 2010 & $\begin{array}{l}\text { Detert \& Trevino } \\
\text { (qualitative study) }\end{array}$ & $\begin{array}{l}\text { Employee voice to } \\
\text { immediate supervisor and } \\
\text { skip-level leaders }\end{array}$ & $\begin{array}{l}\text { Employee perceived } \\
\text { safety and futility } \\
\text { associated with voice, } \\
\text { employee perceived }\end{array}$ & N.A. & N.A. \\
\hline
\end{tabular}




\begin{tabular}{|c|c|c|c|c|c|}
\hline Year & Author(s) & DV(s) & IV(s) & Mediator(s) & Moderator(s) \\
\hline & & & $\begin{array}{l}\text { influence and authority } \\
\text { of the voice target }\end{array}$ & & \\
\hline 2010 & Liu et al. & $\begin{array}{l}\text { Employee voice to leader } \\
\text { and coworker }\end{array}$ & $\begin{array}{l}\text { transformational } \\
\text { leadership }\end{array}$ & $\begin{array}{l}\text { Employee identification } \\
\text { with the organization, } \\
\text { employee identification } \\
\text { with the leader }\end{array}$ & N.A. \\
\hline 2010 & $\begin{array}{l}\text { Venkataramani \& } \\
\text { Tangirala }\end{array}$ & $\begin{array}{l}\text { Employee voice to } \\
\text { supervisor }\end{array}$ & $\begin{array}{l}\text { Employee workflow } \\
\text { centrality (i.e., the extent } \\
\text { to which an employee is } \\
\text { critical to task-related } \\
\text { interaction within the } \\
\text { work group ) }\end{array}$ & $\begin{array}{l}\text { Employee personal } \\
\text { influence }\end{array}$ & $\begin{array}{l}\text { Employee performance } \\
\text { evaluation, employee } \\
\text { workgroup identification }\end{array}$ \\
\hline 2011 & Morrison et al. & $\begin{array}{l}\text { Employee voice to } \\
\text { supervisor }\end{array}$ & $\begin{array}{l}\text { Employee identification } \\
\text { and satisfaction with the } \\
\text { work group }\end{array}$ & N.A. & $\begin{array}{l}\text { Work group's voice } \\
\text { climate }\end{array}$ \\
\hline 2012 & Burris & $\begin{array}{l}\text { Employee performance } \\
\text { evaluation and } \\
\text { supervisory voice } \\
\text { endorsement }\end{array}$ & $\begin{array}{l}\text { Employee self-reported } \\
\text { supportive voice and } \\
\text { challenging voice to } \\
\text { supervisor }\end{array}$ & $\begin{array}{l}\text { Leader perceived loyalty } \\
\text { and threat }\end{array}$ & N.A. \\
\hline 2012 & Liang et al. & $\begin{array}{l}\text { Employee promotive and } \\
\text { prohibitive voice to } \\
\text { supervisor }\end{array}$ & $\begin{array}{l}\text { Employee psychological } \\
\text { safety, employee felt } \\
\text { obligation for } \\
\text { constructive change, } \\
\text { employee organization- } \\
\text { based self-esteem }\end{array}$ & N.A. & N.A. \\
\hline 2012 & $\begin{array}{l}\text { Tangirala \& } \\
\text { Ramanujam }\end{array}$ & $\begin{array}{l}\text { Employee voice to } \\
\text { supervisor }\end{array}$ & $\begin{array}{l}\text { Leader consultation } \\
\text { behavior }\end{array}$ & $\begin{array}{l}\text { Employee personal } \\
\text { influence }\end{array}$ & $\begin{array}{l}\text { Leader status, employee } \\
\text { self-efficacy, employee } \\
\text { overall job satisfaction }\end{array}$ \\
\hline
\end{tabular}




\begin{tabular}{|c|c|c|c|c|c|}
\hline Year & Author(s) & DV(s) & IV(s) & Mediator(s) & Moderator(s) \\
\hline 2012 & Walumbwa et al. & $\begin{array}{l}\text { Group in-role } \\
\text { performance }\end{array}$ & Leader ethical leadership & $\begin{array}{l}\text { Group conscientiousness, } \\
\text { group voice }\end{array}$ & N.A. \\
\hline 2012 & Whiting et al. & $\begin{array}{l}\text { Employee performance } \\
\text { evaluation }\end{array}$ & $\begin{array}{l}\text { Message (whether } \\
\text { employees provide a } \\
\text { solution when they voice, } \\
\text { how the voice is framed: } \\
\text { positive or negative), } \\
\text { source (employee } \\
\text { expertise and } \\
\text { trustworthiness), context } \\
\text { (voice timing, } \\
\text { organizational norms) }\end{array}$ & $\begin{array}{l}\text { Leader liking for the } \\
\text { employee, leader } \\
\text { perceived prosocial } \\
\text { motive and } \\
\text { constructiveness }\end{array}$ & N.A. \\
\hline 2013 & Burris et al. & $\begin{array}{l}\text { Employee performance } \\
\text { evaluation and } \\
\text { involuntary turnover }\end{array}$ & $\begin{array}{l}\text { LMX, employee voice } \\
\text { rated by employee and } \\
\text { supervisor respectively } \\
\text { (i.e., agreement of } \\
\text { employee voice) }\end{array}$ & $\begin{array}{l}\text { Employee performance } \\
\text { evaluation }\end{array}$ & N.A. \\
\hline 2013 & Detert et al. & $\begin{array}{l}\text { Supervisor-rated unit } \\
\text { performance }\end{array}$ & $\begin{array}{l}\text { Flow of voice (i.e., voice } \\
\text { to leader or coworker) }\end{array}$ & $\begin{array}{l}\text { Employee psychological } \\
\text { safety }\end{array}$ & N.A. \\
\hline 2013 & Liu et al. & $\begin{array}{l}\text { Employee voice to } \\
\text { supervisor }\end{array}$ & $\begin{array}{l}\text { Supervisors' } \\
\text { transformational } \\
\text { leadership }\end{array}$ & N.A. & $\begin{array}{l}\text { Employees' belief of } \\
\text { power distance, } \\
\text { hierarchical distance } \\
\text { between employees and } \\
\text { their supervisors }\end{array}$ \\
\hline 2013 & Liu et al. & $\begin{array}{l}\text { Employee voice to } \\
\text { supervisor and skip-level } \\
\text { leader }\end{array}$ & LMX & N.A. & $\begin{array}{l}\text { LLX (exchange between } \\
\text { direct leader and the } \\
\text { skip-level leader), SMX } \\
\text { (exchange between }\end{array}$ \\
\hline
\end{tabular}




\begin{tabular}{|c|c|c|c|c|c|}
\hline Year & Author(s) & DV(s) & IV(s) & Mediator(s) & Moderator(s) \\
\hline & & & & & $\begin{array}{l}\text { employee and the skip- } \\
\text { level leader) }\end{array}$ \\
\hline 2013 & McClean et al. & $\begin{array}{l}\text { Employee turnover at the } \\
\text { unit level }\end{array}$ & $\begin{array}{l}\text { Employee voice to } \\
\text { supervisor at the unit } \\
\text { level by aggregation }\end{array}$ & N.A. & $\begin{array}{l}\text { Manager access to } \\
\text { organizational resources, } \\
\text { manager participation in } \\
\text { decision making, team } \\
\text { change orientation }\end{array}$ \\
\hline 2013 & Tangirala et al. & $\begin{array}{l}\text { Employee voice to } \\
\text { supervisor }\end{array}$ & $\begin{array}{l}\text { Employee duty } \\
\text { orientation and } \\
\text { achievement orientation }\end{array}$ & $\begin{array}{l}\text { Employee voice role } \\
\text { conceptualization }\end{array}$ & $\begin{array}{l}\text { Employee felt efficacy of } \\
\text { voice }\end{array}$ \\
\hline 2014 & Fast et al. & $\begin{array}{l}\text { Employee voice to } \\
\text { supervisor }\end{array}$ & $\begin{array}{l}\text { Leader managerial self- } \\
\text { efficacy }\end{array}$ & $\begin{array}{l}\text { Leader ego threat, leader } \\
\text { aversion to voice }\end{array}$ & N.A. \\
\hline 2015 & Frazier \& Bowler & Group performance & $\begin{array}{l}\text { Group perceptions of } \\
\text { supervisor undermining }\end{array}$ & $\begin{array}{l}\text { Group voice climate, } \\
\text { group voice behavior }\end{array}$ & \\
\hline 2015 & Howell et al. & $\begin{array}{l}\text { Employee performance } \\
\text { evaluation }\end{array}$ & $\begin{array}{l}\text { Employee voice to } \\
\text { supervisor }\end{array}$ & $\begin{array}{l}\text { Supervisory voice } \\
\text { recognition }\end{array}$ & $\begin{array}{l}\text { Employee ascribed status } \\
\text { (ethnicity, gender), } \\
\text { assigned status (tenure) } \\
\text { and achieved status } \\
\text { (advice hub) }\end{array}$ \\
\hline 2015 & Janssen \& Gao & $\begin{array}{l}\text { Employee voice to } \\
\text { supervisor }\end{array}$ & $\begin{array}{l}\text { Supervisory } \\
\text { responsiveness }\end{array}$ & Employee status & $\begin{array}{l}\text { Employee self-efficacy } \\
\text { for voice }\end{array}$ \\
\hline 2015 & Li \& Sun & $\begin{array}{l}\text { Employee voice } \\
\text { supervisor }\end{array}$ & $\begin{array}{l}\text { Skip-level leaders' } \\
\text { authoritarian leadership }\end{array}$ & $\begin{array}{l}\text { Direct supervisors' } \\
\text { authoritarian leadership }\end{array}$ & $\begin{array}{l}\text { Direct supervisors' } \\
\text { identification with skip- } \\
\text { level leaders, employees' } \\
\text { power distance } \\
\text { orientation }\end{array}$ \\
\hline
\end{tabular}




\begin{tabular}{|c|c|c|c|c|c|}
\hline Year & Author(s) & DV(s) & IV(s) & Mediator(s) & Moderator(s) \\
\hline 2015 & Lin \& Johnson & $\begin{array}{l}\text { Employee promotive and } \\
\text { prohibitive voice at a } \\
\text { later time point }\end{array}$ & $\begin{array}{l}\text { Employee regulatory } \\
\text { focus (promotion vs. } \\
\text { prevention focus) }\end{array}$ & $\begin{array}{l}\text { Employee promotive and } \\
\text { prohibitive voice at an } \\
\text { earlier time point; } \\
\text { employee depletion }\end{array}$ & N.A. \\
\hline 2015 & Liu et al. & $\begin{array}{l}\text { Employee voice to } \\
\text { supervisor }\end{array}$ & $\begin{array}{l}\text { Voice target's positive } \\
\text { mood (leader, coworker) }\end{array}$ & $\begin{array}{l}\text { Employee psychological } \\
\text { safety }\end{array}$ & $\begin{array}{l}\text { LMX, CMX, relative } \\
\text { status between voicer and } \\
\text { voice target }\end{array}$ \\
\hline 2015 & $\begin{array}{l}\text { Ng \& Feldman } \\
\text { (meta-analysis) }\end{array}$ & $\begin{array}{l}\text { Employee in-role } \\
\text { performance, creativity } \\
\text { performance, employee } \\
\text { self-rated implementation } \\
\text { of their voice }\end{array}$ & $\begin{array}{l}\text { Job-, interpersonal } \\
\text { relationship-, } \\
\text { organization-related } \\
\text { stressors }\end{array}$ & Employee voice & $\begin{array}{l}\text { Source of rating (i.e., } \\
\text { self-rating of voice vs. } \\
\text { other-rating of voice), } \\
\text { countries (eastern vs. } \\
\text { western countries) }\end{array}$ \\
\hline 2015 & Wei et al. & $\begin{array}{l}\text { Employee promotive } \\
\text { voice and prohibitive } \\
\text { voice }\end{array}$ & $\begin{array}{l}\text { Leader power distance, } \\
\text { employee perceived } \\
\text { superficial harmony }\end{array}$ & $\begin{array}{l}\text { Employee perceived } \\
\text { efficacy and risk of } \\
\text { promotive and } \\
\text { prohibitive voice }\end{array}$ & $\begin{array}{l}\text { Leader delegation } \\
\text { behavior, group voice } \\
\text { climate }\end{array}$ \\
\hline 2016 & Kakkar et al. & $\begin{array}{l}\text { Employee promotive } \\
\text { voice and prohibitive } \\
\text { voice }\end{array}$ & $\begin{array}{l}\text { Employee approach } \\
\text { motivation and avoidance } \\
\text { motivation }\end{array}$ & N.A. & $\begin{array}{l}\text { Employee voice role } \\
\text { expectation }\end{array}$ \\
\hline 2016 & Kong et al. & $\begin{array}{l}\text { Employee promotive and } \\
\text { prohibitive voice }\end{array}$ & $\begin{array}{l}\text { Employee need for } \\
\text { affiliation }\end{array}$ & LMX & Group cohesion \\
\hline 2016 & Ward et al. & $\begin{array}{l}\text { Employee promotive } \\
\text { voice and prohibitive } \\
\text { voice }\end{array}$ & $\begin{array}{l}\text { Contextual } \\
\text { communication } \\
\text { orientation }\end{array}$ & N.A. & LMX \\
\hline 2017 & Aryee et al. & $\begin{array}{l}\text { Employee voice to } \\
\text { supervisor }\end{array}$ & $\begin{array}{l}\text { Employee core self- } \\
\text { evaluation }\end{array}$ & $\begin{array}{l}\text { Employee personal } \\
\text { control, employee } \\
\text { approach motivation, }\end{array}$ & $\begin{array}{l}\text { Employee perceived } \\
\text { procedural justice }\end{array}$ \\
\hline
\end{tabular}




\begin{tabular}{|c|c|c|c|c|c|}
\hline Year & Author(s) & DV(s) & IV(s) & Mediator(s) & Moderator(s) \\
\hline & & & & $\begin{array}{l}\text { employee avoidance } \\
\text { motivation }\end{array}$ & \\
\hline 2017 & $\begin{array}{l}\text { Chamberlin et al. } \\
\text { (meta-analysis) }\end{array}$ & $\begin{array}{l}\text { Employee job } \\
\text { performance }\end{array}$ & $\begin{array}{l}\text { Employee dispositions } \\
\text { (i.e., big five, CSE, } \\
\text { PANA), employee job } \\
\text { attitudes (e.g., job } \\
\text { satisfaction, } \\
\text { organizational } \\
\text { commitment), employee } \\
\text { emotions and beliefs } \\
\text { (e.g., psychological } \\
\text { safety, futility, fear), } \\
\text { leadership (e.g., } \\
\text { transformational } \\
\text { leadership, LMX, } \\
\text { abusive supervision), } \\
\text { contextual factors (e.g., } \\
\text { workplace stress and } \\
\text { climate) }\end{array}$ & Employee voice & $\begin{array}{l}\text { Sample population, job } \\
\text { type, source of rating }\end{array}$ \\
\hline 2017 & Hsiung \& Tsai & $\begin{array}{l}\text { Employee promotive } \\
\text { voice and prohibitive } \\
\text { voice }\end{array}$ & $\begin{array}{l}\text { Leader power distance } \\
\text { orientation }\end{array}$ & N.A. & $\begin{array}{l}\text { Employee activated } \\
\text { negative mood, group } \\
\text { voice climate }\end{array}$ \\
\hline 2017 & Burris et al. & $\begin{array}{l}\text { Managerial assessment of } \\
\text { the value of voice (i.e., } \\
\text { voice endorsement) }\end{array}$ & $\begin{array}{l}\text { Employee identification } \\
\text { with the work unit; } \\
\text { employee identification } \\
\text { with the profession }\end{array}$ & $\begin{array}{l}\text { Voice content (three } \\
\text { dimensions: } 1 \text {. the } \\
\text { importance of initiating } \\
\text { change, } 2 . \text { the required } \\
\text { resources to enact the } \\
\text { desired change, and } 3 \text {. } \\
\text { the interdependencies }\end{array}$ & N.A. \\
\hline
\end{tabular}




\begin{tabular}{|c|c|c|c|c|c|}
\hline Year & Author(s) & DV(s) & IV(s) & Mediator(s) & Moderator(s) \\
\hline & & & & $\begin{array}{l}\text { involved in implementing } \\
\text { the desired change) }\end{array}$ & \\
\hline 2017 & McClean et al. & $\begin{array}{l}\text { Employee promotive and } \\
\text { prohibitive voice }\end{array}$ & $\begin{array}{l}\text { Employees' leadership } \\
\text { emergence }\end{array}$ & Employee status & Employee gender \\
\hline 2017 & Liu et al. & Employee voice & $\begin{array}{l}\text { Leader affect self- } \\
\text { reported by leaders }\end{array}$ & $\begin{array}{l}\text { Employees' } \\
\text { psychological safety, } \\
\text { employee-reported leader } \\
\text { affect, employee self- } \\
\text { reported affect }\end{array}$ & Employee reported LMX \\
\hline 2017 & Li et al. & $\begin{array}{l}\text { Team productivity } \\
\text { performance gains, team } \\
\text { safety performance gains }\end{array}$ & $\begin{array}{l}\text { Team prohibitive and } \\
\text { promotive voice }\end{array}$ & $\begin{array}{l}\text { Team innovation, team } \\
\text { monitoring }\end{array}$ & N.A. \\
\hline 2018 & Farh \& Chen & Employee voice & $\begin{array}{l}\text { Leader supportive } \\
\text { behavior, coaching } \\
\text { behavior, and directing } \\
\text { behavior }\end{array}$ & N.A. & $\begin{array}{l}\text { Employees' familiarity } \\
\text { with one another in teams }\end{array}$ \\
\hline 2018 & Jiang et al. & Employee voice & $\begin{array}{l}\text { Employee critical } \\
\text { thinking, leader } \\
\text { inspirational motivation }\end{array}$ & Employee voice efficacy & N.A. \\
\hline 2018 & Li et al. & $\begin{array}{l}\text { Employee promotive and } \\
\text { prohibitive voice }\end{array}$ & $\begin{array}{l}\text { Employee perceived } \\
\text { organizational politics }\end{array}$ & $\begin{array}{l}\text { Employee psychological } \\
\text { uncertainty }\end{array}$ & $\begin{array}{l}\text { Job autonomy, job } \\
\text { security }\end{array}$ \\
\hline 2018 & Lam et al. & $\begin{array}{l}\text { Supervisors' voice } \\
\text { endorsement }\end{array}$ & Employee voice & N.A. & $\begin{array}{l}\text { Voicers' credibility and } \\
\text { politeness }\end{array}$ \\
\hline 2018 & Huang et al. & $\begin{array}{l}\text { Supervisor-rated } \\
\text { promotability and } \\
\text { performance for } \\
\text { employees }\end{array}$ & $\begin{array}{l}\text { Employee promotive and } \\
\text { prohibitive voice } \\
\text { behavior }\end{array}$ & $\begin{array}{l}\text { Supervisor perceived } \\
\text { constructiveness of } \\
\text { employee voice }\end{array}$ & LMX \\
\hline
\end{tabular}


Table 3. Descriptive Statistics and Bivariate Correlations

\begin{tabular}{|c|c|c|c|c|c|c|c|c|c|c|c|c|}
\hline & & $\mathrm{M}$ & $\mathrm{SD}$ & 1 & 2 & 3 & 4 & 5 & 6 & 7 & 8 & 9 \\
\hline 1 & Loyalty & 5.43 & 1.02 & .92 & & & & & & & & \\
\hline 2 & LMX & 3.82 & 0.69 & $.50 * *$ & .90 & & & & & & & \\
\hline 3 & Voice & 3.06 & 0.94 & $.53 * *$ & $.27 * *$ & .85 & & & & & & \\
\hline 4 & Political skill & 4.62 & 1.03 & $.46^{* *}$ & $.39 * *$ & $.46^{* *}$ & .95 & & & & & \\
\hline 6 & Self-serving motive attribution & 4.16 & 1.30 & .03 & .08 & .11 & $.27 * *$ & .02 & .91 & & & \\
\hline 7 & Perceived Instrumentality & 4.67 & 0.81 & $.26^{* *}$ & .09 & $.30 * *$ & $.18^{* *}$ & $.35^{* *}$ & -.09 & .87 & & \\
\hline 8 & Endorsement & 3.61 & 0.73 & $.29 * *$ & .08 & $.37 * *$ & $.19 * *$ & $.37 * *$ & -.08 & $.65^{* *}$ & .93 & \\
\hline
\end{tabular}

Note. $\mathrm{N}=291 .{ }^{*} p<.01 . \mathrm{SD}=$ standard deviation. Reliability coefficients appear in bold italic along the diagonal. LMX = leader-member exchange relationship. 
Table 4. Comparisons of Measurement Models of Studied Variables

\begin{tabular}{|c|c|c|c|c|c|c|c|}
\hline Model & Description & $\chi^{2}$ & $\overline{d f}$ & $\mathrm{CFI}$ & TLI & RMSEA & $\Delta \chi^{2}(\mathrm{df})$ \\
\hline 1 & Hypothesized seven-factor model & 448.47 & 254 & .97 & .96 & .05 & Baseline \\
\hline 2 & $\begin{array}{l}\text { Six-factor model (endorsement and implementation } \\
\text { were combined) }\end{array}$ & 1126.41 & 260 & .86 & .84 & .11 & $677.94(6)^{* *}$ \\
\hline 3 & $\begin{array}{l}\text { Five-factor model (endorsement, implementation, } \\
\text { and instrumentality were combined) }\end{array}$ & 1471.01 & 265 & .81 & .79 & .13 & $1022.54(11)^{* *}$ \\
\hline 4 & $\begin{array}{l}\text { Four-factor model (endorsement, implementation, } \\
\text { and instrumentality were combined; motive } \\
\text { attributions were combined) }\end{array}$ & 2637.24 & 269 & .63 & .59 & .17 & $2188.77(15)^{* *}$ \\
\hline 5 & $\begin{array}{l}\text { Three-factor model (endorsement, implementation, } \\
\text { instrumentality, motive attributions were combined) }\end{array}$ & 3421.90 & 272 & .51 & .46 & .20 & $2973.43(18)^{* *}$ \\
\hline 6 & $\begin{array}{l}\text { Two-factor model (Supervisor-rated versus employee } \\
\text { rated) }\end{array}$ & 3708.64 & 274 & .46 & .41 & .21 & $3260.17(20)^{* *}$ \\
\hline 7 & One-factor model & 4351.22 & 275 & .36 & .30 & .23 & $3902.75(21)^{* * *}$ \\
\hline
\end{tabular}

Note. $\mathrm{N}=291 ; * * p<.01$. The hypothesized seven-factor model served as the baseline model. All alternative models were compared with it. CFI = comparative fit index; TLI = Tucker-Lewis index; RMSEA = Root mean squared error of approximation. 
Table 5. HLM Analyses for Hypothesis Testing

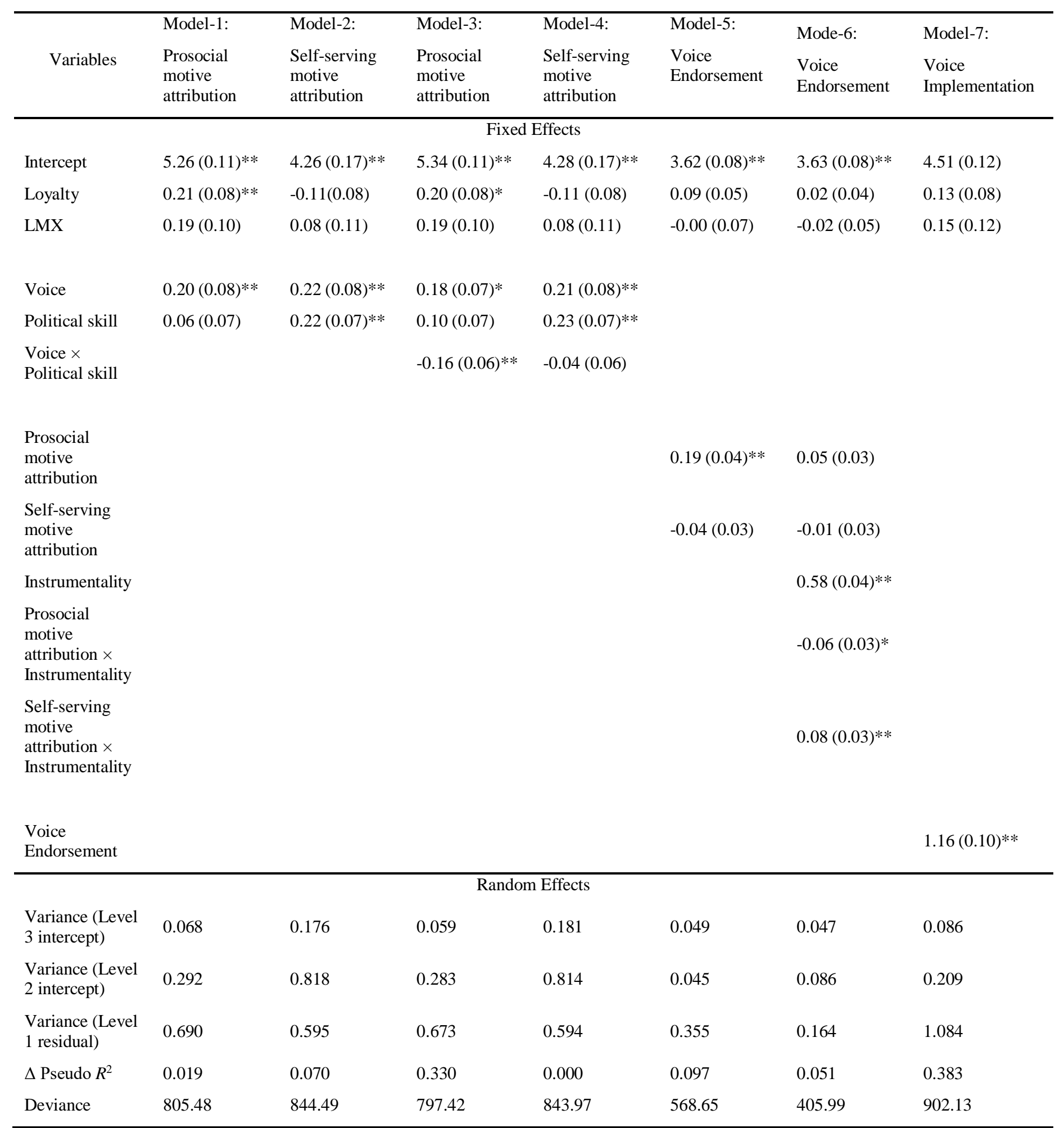

Note. $\mathrm{N}=291 .{ }^{*} p<.05 ; * * p<.01$. Table entries represent unstandardized parameter estimates with standard errors in parentheses. The model 1, 2, and 5 list the main effects. 
Table 6. Moderated Mediation Effects of Prosocial Motive Attribution in the Relationship between Employee Voice and Supervisor Voice Endorsement/Voice Implementation at Conditional Values of Political Skill and Perceived Instrumentality

\begin{tabular}{|c|c|c|c|}
\hline & Moderator variables & Effects & \\
\hline \multirow{3}{*}{$\begin{array}{l}\text { Political } \\
\text { skill }\end{array}$} & \multirow{3}{*}{$\begin{array}{c}\text { Perceived } \\
\text { instrumentality }\end{array}$} & Conditional indirect effects on & Conditional indirect effects on \\
\hline & & Voice Endorsement & Voice Implementation \\
\hline & & [Bias-corrected 95\% CI] & [Bias-corrected 95\% CI] \\
\hline Low & Low & $0.036[0.014, \quad 0.067]$ & $0.042[0.017,0.079]$ \\
\hline Low & High & $0.000[-0.013,0.032]$ & $0.001[-0.013,0.038]$ \\
\hline High & Low & $0.002[-0.021,0.027]$ & $0.002[-0.028,0.026]$ \\
\hline High & High & $0.000[-0.007,0.016]$ & $0.000[-0.008,0.016]$ \\
\hline
\end{tabular}

Note. $\mathrm{N}=291$. I bootstrapped 2500 times to calculate the bias-corrected $95 \%$ confidence interval (CI). 
Table 7. Moderated Mediation Effects of Self-Serving Motive Attribution in the Relationship between Employee Voice and Supervisor Voice Endorsement/Voice Implementation at Conditional Values of Perceived Instrumentality

\begin{tabular}{|c|c|c|}
\hline \multirow[t]{3}{*}{ Perceived instrumentality } & Conditional indirect effects on & Conditional indirect effects on \\
\hline & Voice Endorsement & Voice Implementation \\
\hline & [Bias-corrected 95\% CI] & [Bias-corrected 95\% CI] \\
\hline Low & $-0.018[-0.038,-0.068]$ & $-0.020[-0.039,-0.008]$ \\
\hline High & $0.012[0.001,0.037]$ & $0.014[0.002,0.038]$ \\
\hline
\end{tabular}

Note. $\mathrm{N}=291$. I bootstrapped 2500 times to calculate the bias-corrected $95 \%$ confidence interval (CI). 
Figure 1. The Conceptual Model

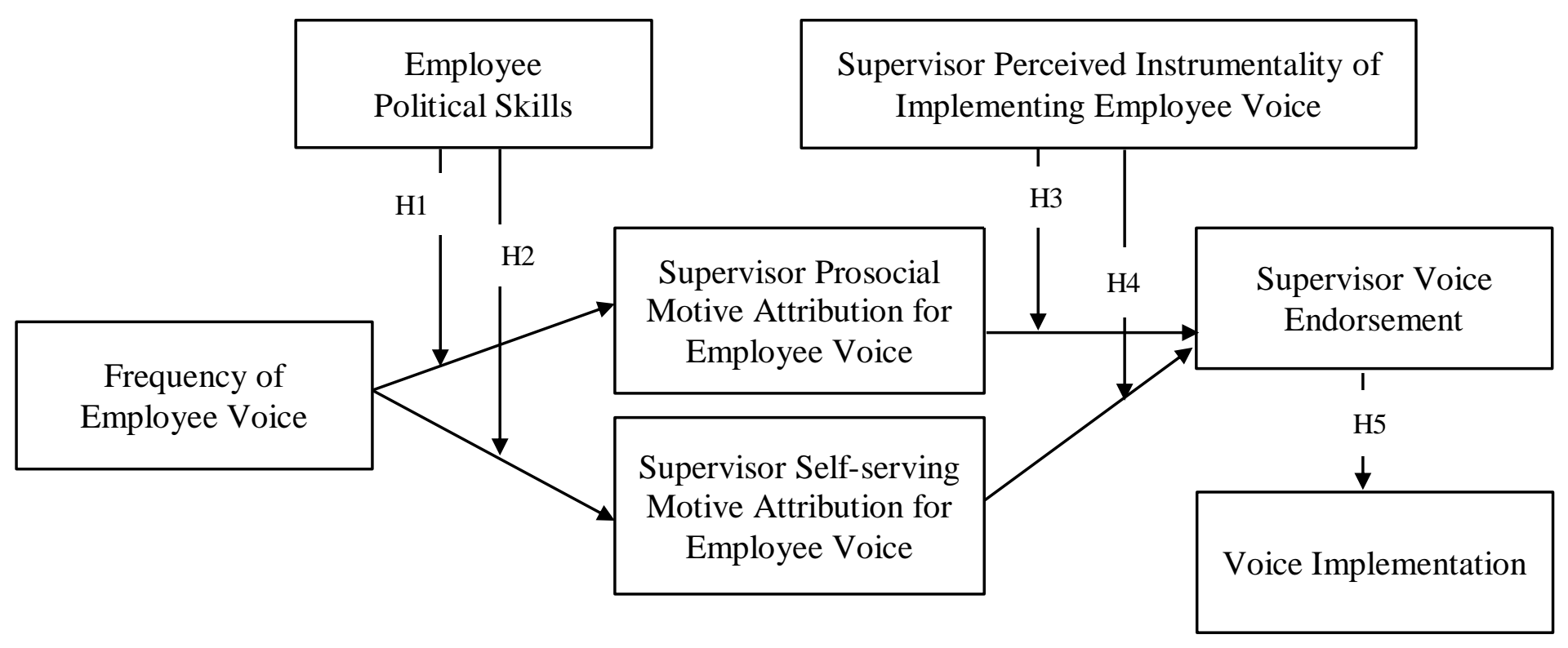


Figure 2. Political skill as a moderator of the relationship between employee voice and supervisor prosocial motive attribution

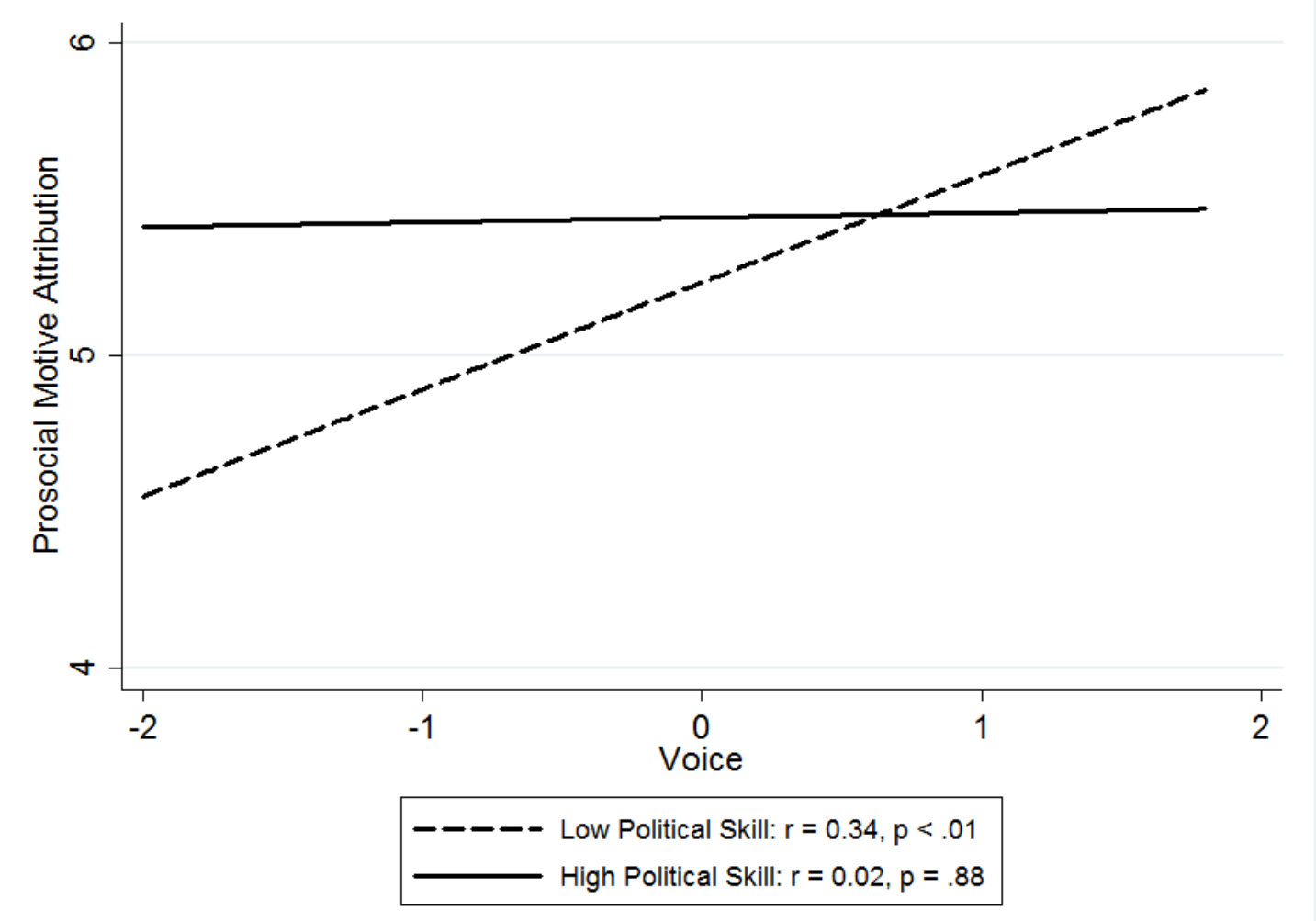


Figure 3. Perceived Instrumentality as a moderator of the relationship between supervisor prosocial motive attribution and supervisor endorsement of employee ideas

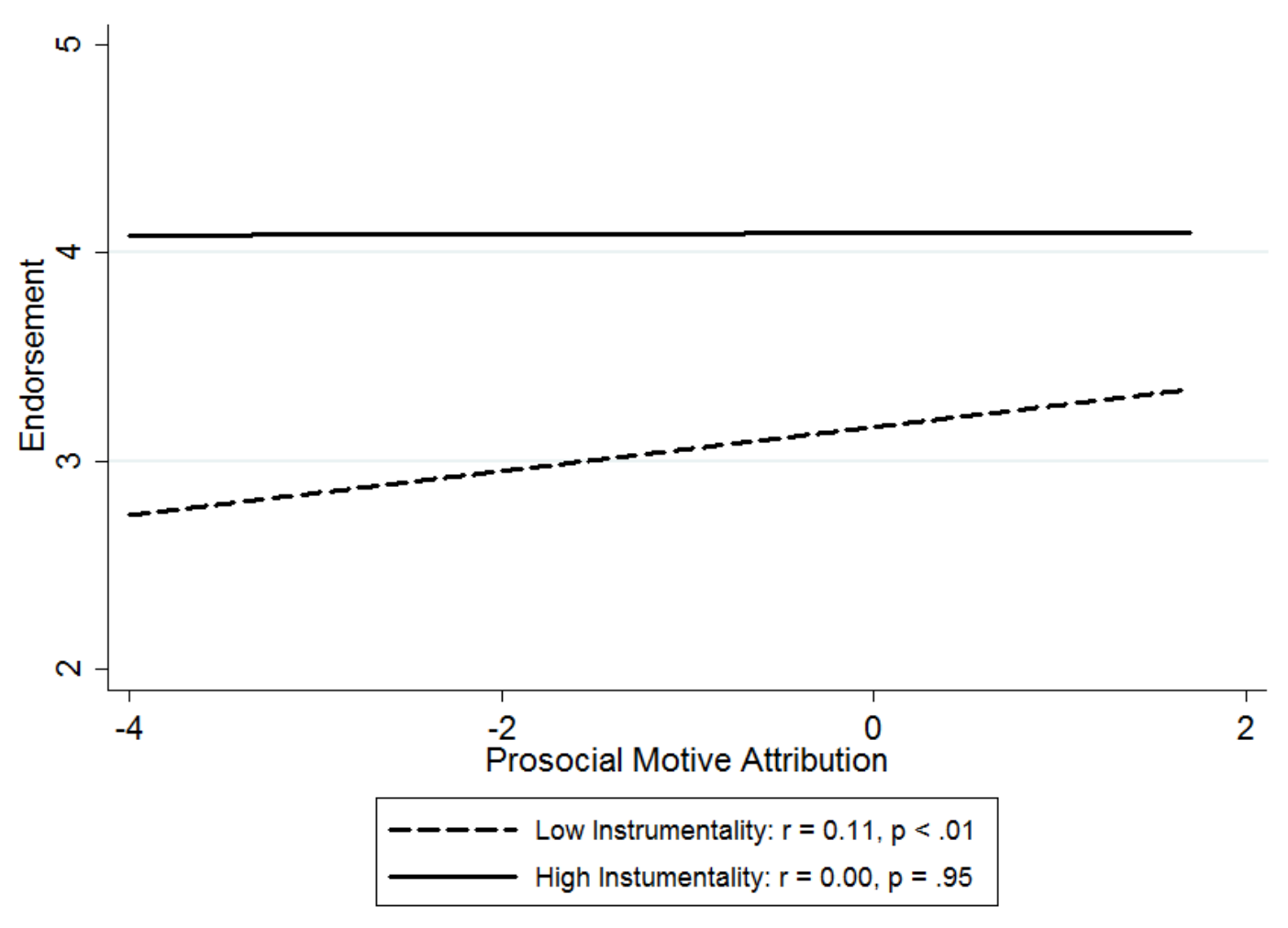


Figure 4. Perceived Instrumentality as a moderator of the relationship between supervisor selfserving motive attribution and supervisor endorsement of employee ideas

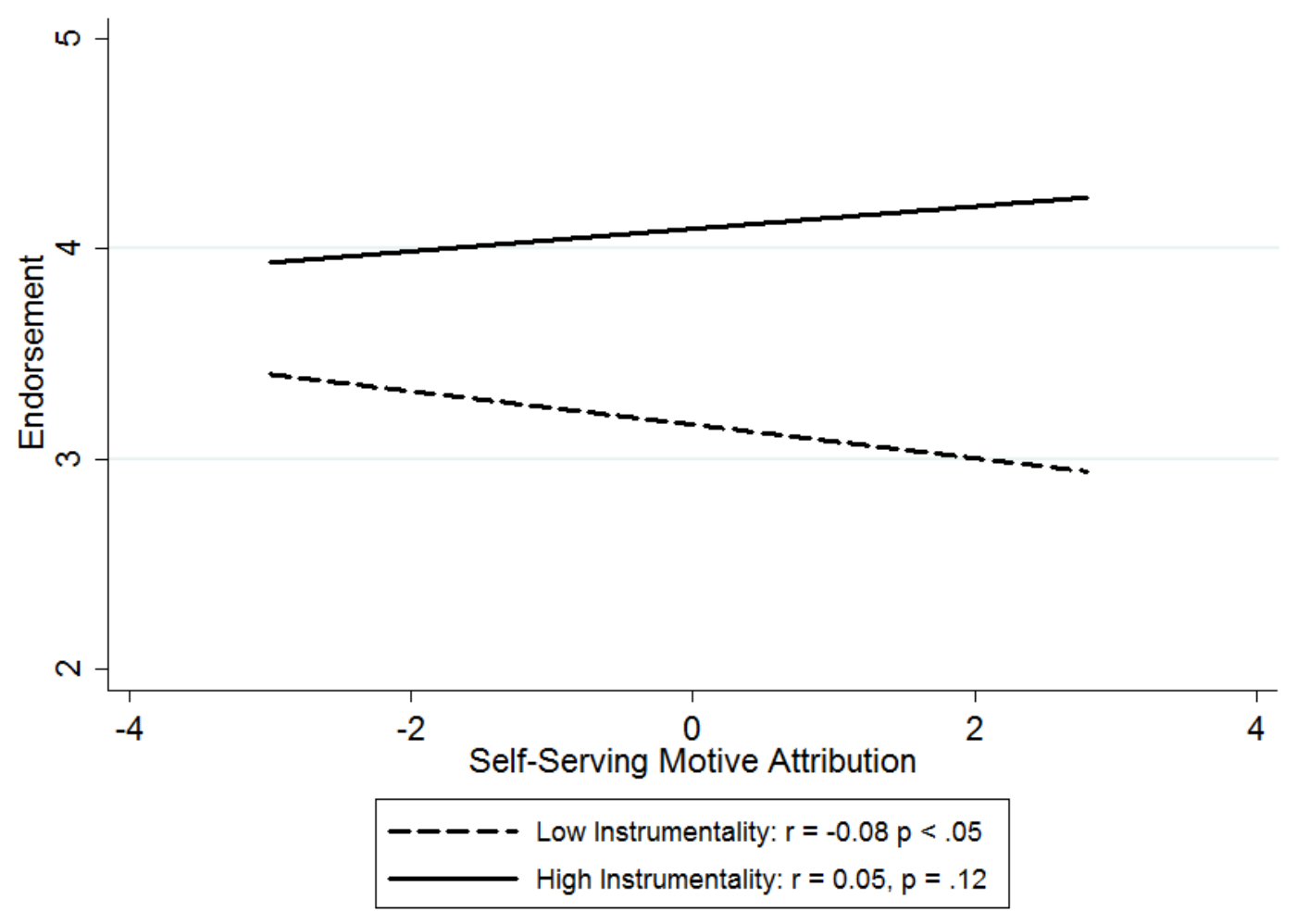


Figure 5. The Research Model with Path Coefficients

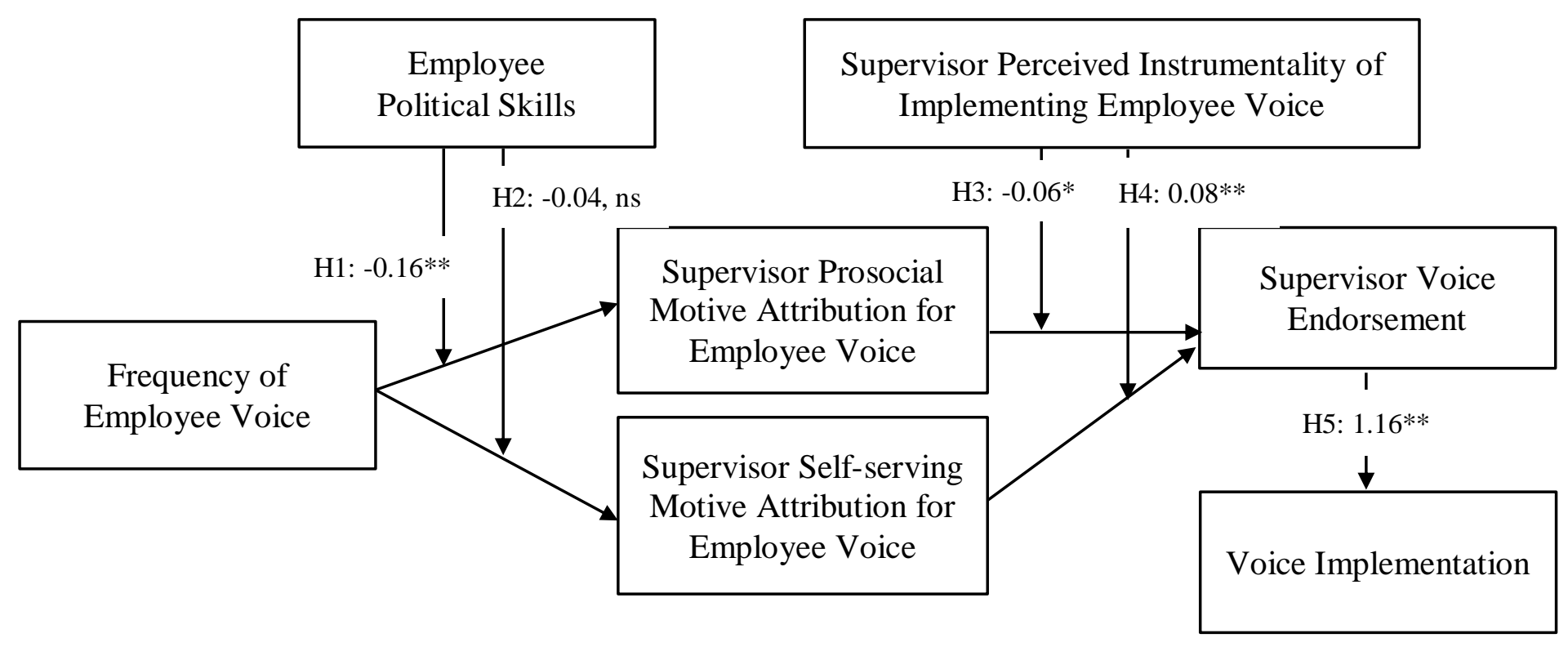




\section{Appendix A. Survey Instruments Used in the Study}

\section{Voice (Burris, 2012; Burris et al., 2008)}

5-point frequency scale ranging from 1 (almost never) to 5 (almost always)

1. I challenge my supervisor to deal with problems around here.

2. I give suggestions to my supervisor about how to make our unit or organization better, even if others disagree.

3. I speak up to my supervisor with ideas to address employees' needs and concerns.

\section{Political Skill Inventory (PSI, Ferris et al., 2005)}

A 7-point Likert scale ranging from 1 (strongly disagree) to 7 (strongly agree)

\section{Networking Ability}

1. I spend a lot of time and effort at work networking with others.

2. At work, I know a lot of important people and am well connected.

3. I am good at using my connections and networks to make things happen at work.

4. I have developed a large network of colleagues and associates at work who I can call on for support when I really need to get things done.

5. I spend a lot of time at work developing connections with others.

6. I am good at building relationships with influential people at work.

\section{Apparent Sincerity}

7. It is important that people believe I am sincere in what I say and do.

8. When communicating with others, I try to be genuine in what I say and do.

9. I try to show a genuine interest in other people.

\section{Social Astuteness}

10. I always seem to instinctively know the right thing to say or do to influence others.

11. I have good intuition or savvy about how to present myself to others.

12. I am particularly good at sensing the motivations and hidden agendas of others.

13. I pay close attention to people's facial expressions.

14. I understand people very well.

\section{Interpersonal Influence}

15. It is easy for me to develop good rapport with most people.

16. I am able to make most people feel comfortable and at ease around me.

17. I am able to communicate easily and effectively with others.

18. I am good at getting people to like me. 


\section{Prosocial Motive Attribution (Grant, 2008)}

The introductory question: Why do you think this employee engages in voice behavior?

A 7-point Likert scale ranging from 1 (strongly disagree) to 7 (strongly agree).

1. Because this employee cares about benefiting others through his/her voice behavior.

2. Because this employee wants to help others through his/her voice behavior.

3. Because this employee wants to have positive impact on others through his/her voice behavior.

4. Because it is important to this employee to do good for others through his/her voice behavior.

\section{Self-serving Motive Attribution (Rioux \& Penner, 2001)}

The introductory question: Why do you think this employee engages in voice behavior?

A 7-point Likert scale ranging from 1 (strongly disagree) to 7 (strongly agree).

1. To avoid looking bad in front of others.

2. To avoid looking lazy.

3. To look better than others.

4. To avoid a reprimand from me.

5. Because he/she fears appearing irresponsible.

6. To look like he/she is busy.

7. To stay out of trouble.

8. Because rewards are important to him/her.

9. Because he/she wants a raise.

10. To impress others.

\section{Perceived Implementation Instrumentality (Baer, 2012)}

The introductory question: Here are some things that could happen to people if they tried to turn their employees' ideas into a new product, process, or procedure that is actually brought to market or implemented. How likely is it that each of these things would happen if you tried to implement the suggested changes brought up by this employee?

A 7-point Likert scale ranging from 1 (strongly disagree) to 7 (strongly agree)

1. My supervisor will praise me and my work.

2. I will enhance my reputation as someone who can get things done.

3. I will get a bonus or pay increase.

4. I will get a promotion or a better job. 
5. I will get the feeling that I have accomplished something worthwhile.

6. I will be given chances to learn new things.

7. The current work procedure or situation will be improved.

8. I will encounter resistance or active opposition. (reverse-coded)

9. I will get the resources necessary to tackle other, even bigger projects.

\section{Voice Endorsement (Burris, 2012)}

A 5-point Likert scale ranges from 1 (strongly disagree/very unlikely) to 5 (strongly agree/very likely)

1. How likely is it that you will take this employee's comments to your supervisors? ( $1=$ very unlikely; $5=$ very likely)

2. How likely is it that you will support this employee's comments when talking with your supervisors? (1=very unlikely; 5=very likely)

3. I think this employee's comments should be implemented. ( $1=$ strongly disagree; $5=$ strongly agree)

4. I agree with this employee's comments. (1=strongly disagree; 5=strongly agree)

5. This employee's comments are valuable. (1=strongly disagree; 5=strongly agree)

\section{Voice Implementation (Baer, 2012)}

A 7-point Likert scale ranges from 1 (never) to 7 (always)

Please rate the frequency with which this employee's ideas ...

1. ... have been approved for further development.

2. ... have been transformed into usable products, processes, or procedures.

3. ... have been successfully brought to market or have been successfully implemented.

\section{Loyalty of Employee (Boroff \& Lewin, 1997; Olson-Buchanan \& Boswell, 2002)}

A 7-point Likert-type Scale ranging from 1 (strongly disagree) to 7 (strongly agree).

1. I represent the organization favorably to outsiders.

2. I go out of the way to defend the organization against outside threat.

3. I tell outsiders this is a good place to work.

4. I defend the organization when others criticize it.

5. I actively promote the organization's products and services.

6. I would accept a job at a competing organization for more money. (reverse-coded) 
7. I would urge coworkers to invest money in this organization.

\section{LMX (Liden et al., 1993)}

A 5-point Likert-type Scale ranging from 1 (stronger disagree) to 5 (strongly agree) for the first six items and from 1 (ineffective) to 5 (extremely effective) for the last item.

1. Regardless of how much power my supervisor has built into his/her position, my supervisor would be personally inclined to use his/her power to help me solve problems in my work.

2. I can count on my supervisor to "bail me out," even at his or her own expense, when I really need it.

3. My supervisor understands my problems and needs.

4. My supervisor recognizes my potential.

5. My supervisor has enough confidence in me that he/she would defend and justify my decisions if I were not present to do so.

6. I usually know where I stand with my supervisor.

7. How would you describe your working relationship with your supervisor? 


\section{Appendix B. Original Survey Instruments Developed by Scholars*}

*The survey instruments used in this study are the same as the original scales developed by scholars. The only differences are the introductory questions of Prosocial Motive Scale, Selfserving Motive Scale, and Perceived Instrumentality Scale. I adjusted the introductory questions to the voice context.

Voice (Burris, 2012; Burris et al., 2008)

A 5-point frequency scale ranging from 1 (almost never) to 5 (almost always)

1. I challenge my district manager to deal with problems around here.

2. I give suggestions to my district manager about how to make this restaurant better, even if others disagree.

3. I speak up to my district manager with ideas to address employees' needs and concerns.

\section{Political Skill Inventory (PSI, Ferris et al., 2005)}

A 7-point Likert scale ranging from 1 (strongly disagree) to 7 (strongly agree)

\section{Networking Ability}

1. I spend a lot of time and effort at work networking with others.

2. At work, I know a lot of important people and am well connected.

3. I am good at using my connections and networks to make things happen at work.

4. I have developed a large network of colleagues and associates at work who I can call on for support when I really need to get things done.

5. I spend a lot of time at work developing connections with others.

6. I am good at building relationships with influential people at work.

\section{Apparent Sincerity}

7. It is important that people believe I am sincere in what I say and do.

8. When communicating with others, I try to be genuine in what I say and do.

9. I try to show a genuine interest in other people.

Social Astuteness

10. I always seem to instinctively know the right thing to say or do to influence others.

11. I have good intuition or savvy about how to present myself to others.

12. I am particularly good at sensing the motivations and hidden agendas of others.

13. I pay close attention to people's facial expressions.

14. I understand people very well. 
15. It is easy for me to develop good rapport with most people.

16. I am able to make most people feel comfortable and at ease around me.

17. I am able to communicate easily and effectively with others.

18. I am good at getting people to like me.

Prosocial Motive Attribution (Grant, 2008)

The introductory question: Why are you motivated to do your work?

A 7-point Likert scale ranging from 1 (strongly disagree) to 7 (strongly agree).

1. Because I care about benefiting others through my work.

2. Because I want to help others through my work.

3. Because I want to have positive impact on others through my work.

4. Because it is important to me to do good for others through my work.

\section{Self-serving Motive Attribution (Rioux \& Penner, 2001)}

The introductory question: How important each motive statement would be in this employee's decision to engage in $\mathrm{OCB}$ at a job?

A 6-point Likert scale ranging from 1 (not at all important) to 6 (extremely important).

1. To avoid looking bad in front of others.

2. To avoid looking lazy.

3. To look better than my co-workers.

4. To avoid a reprimand from my boss.

5. Because he/she fears appearing irresponsible.

6. To look like he/she is busy.

7. To stay out of trouble.

8. Because rewards are important to me.

9. Because he/she wants a raise.

10. To impress my co-workers.

\section{Perceived Implementation Instrumentality (Baer, 2012)}

The introductory question: Here are some things that could happen to people if they tried to turn their ideas into a new product, process, or procedure that is actually brought to market or implemented at [organization]. How likely is it that each of these things would happen if you tried to implement one of your ideas? 
A 7-point Likert scale ranging from 1 (strongly disagree) to 7 (strongly agree)

1. My supervisor will praise me and my work.

2. I will enhance my reputation as someone who can get things done.

3. I will get a bonus or pay increase.

4. I will get a promotion or a better job.

5. I will get the feeling that I have accomplished something worthwhile.

6. I will be given chances to learn new things.

7. The current work procedure or situation will be improved.

8. I will encounter resistance or active opposition. (reverse-scored)

9. I will get the resources necessary to tackle other, even bigger projects.

\section{Voice Endorsement (Burris, 2012)}

A 5-point Likert scale ranges from 1 (strongly disagree/very unlikely) to 5 (strongly agree/very likely)

1. How likely is it that you will take this employee's comments to your supervisors? $(1=$ very unlikely; $5=$ very likely $)$

2. How likely is it that you will support this employee's comments when talking with your supervisors? $(1=$ very unlikely; $5=$ very likely $)$

3. I think this employee's comments should be implemented. ( $1=$ strongly disagree; $5=$ strongly agree)

4. I agree with this employee's comments. ( $1=$ strongly disagree; $5=$ strongly agree)

5. This employee's comments are valuable. ( $1=$ strongly disagree; $5=$ strongly agree $)$

\section{Voice Implementation (Baer, 2012)}

A 7-point Likert scale ranges from 1 (never) to 7 (always)

Please rate the frequency with which, in the past, this employee's ideas ...

1. ... have been approved for further development.

2. ... have been transformed into usable products, processes, or procedures.

3. ... have been successfully brought to market or have been successfully implemented. 
Loyalty of Employee (Boroff \& Lewin, 1997; Olson-Buchanan \& Boswell, 2002)

A 7-point Likert-type Scale ranging from 1 (strongly disagree) to 7 (strongly agree).

1. I represent the organization favorably to outsiders.

2. I go out of the way to defend the organization against outside threat.

3. I tell outsiders this is a good place to work.

4. I defend the organization when others criticize it.

5. I actively promote the organization's products and services.

6. I would accept a job at a competing organization for more money. (reverse coded)

7. I would urge coworkers to invest money in this organization.

\section{LMX (Liden et al., 1993)}

A 5-point Likert-type Scale ranging from 1 (stronger disagree) to 5 (strongly agree) for the first six items and from 1 (ineffective) to 5 (extremely effective) for the last item.

1. Regardless of how much power my supervisor has built into his/her position, my supervisor would be personally inclined to use his/her power to help me solve problems in my work.

2. I can count on my supervisor to "bail me out," even at his or her own expense, when I really need it.

3. My supervisor understands my problems and needs.

4. My supervisor recognizes my potential.

5. My supervisor has enough confidence in me that he/she would defend and justify my decisions if I were not present to do so.

6. I usually know where I stand with my supervisor.

7. How would you describe your working relationship with your supervisor? 